\title{
Creating Design Principles of a Learning Environment for Teaching Vector Spaces *
}

\author{
Gökay Açıkyıldız ${ }^{a}$ and Temel Kösa ${ }^{b}$

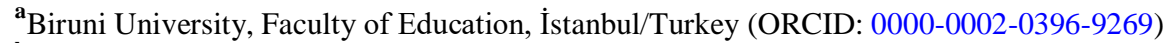 \\ ${ }^{\mathbf{b}}$ Trabzon University, Fatih Faculty of Education, Trabzon/Turkey (ORCID: 0000-0002-4302-1018)
}

Article History: Received: 13 January 2021; Accepted: 2 February 2021; Published online: 5 February 2021

\begin{abstract}
In this study, determining the design principles of a technology-supported learning environment for teaching vector spaces by taking into account the representation languages defined by Hillel (2000), Harel's (2000) pedagogical principles and Sierpinska's (2000) thinking modes on Linear Algebra teaching were intended to be established. The research is a design-based research and three cycles were conducted to determine the design principles for the learning environment. The study group of the first cycle consists of 51, the second cycle's working group was 44 , and the third cycle's study group consisted of 11 teacher candidates. The data of the research were obtained by field notes and video recordings. By analyzing the field notes and video recordings, design principles for the learning environment were determined after the first two cycles in light of the literature. The third cycle was carried out with the determined design principles, and the design principles were revised in line with the opinions of the teacher candidates and the course teacher after the application with the reports obtained during the application process. Design principles in the light of the results obtained from the research are as follows ; the use of technology, usage of modes of description, tasks, worksheets, the role of the teacher and group work. It is thought that a learning environment that will be created by paying attention to these design principles will contribute to the pre-service teachers' differentiation and use of different languages, the development of thinking styles, and to meet the principles of concreteness, necessity and generalizability.
\end{abstract}

Keywords: Linear algebra, vector spaces, learning environment, design principles, technology, desing-based research

DOI:10.16949/turkbilmat.860627

Öz: Bu çalışmada Lineer Cebir öğretimi üzerine Hillel'in (2000) tanımladığı temsil dilleri, Harel'in (2000) pedagojik prensipleri ve Sierpinska'nın (2000) düşünme biçimleri göz önünde bulundurularak vektör uzaylarının öğretimine yönelik teknoloji destekli bir öğrenme ortamının tasarım ilkelerinin belirlenmesi amaçlanmıştır. Araştırma, tasarım tabanlı bir araştırma olup öğrenme ortamına yönelik tasarım ilkelerinin belirlenmesi için üç döngü gerçekleştirilmiştir. Birinci döngünün çalışma grubunu 51, ikinci döngünün çalışma grubunu 44 ve üçüncü döngünün çalışma grubunu 11 öğretmen adayı oluşturmaktadır. Araştırmanın verileri alan notları ve video kayıtları ile elde edilmiştir. Alan notları ve video kayıtları analiz edilerek literatür 1şığında ilk iki döngü sonrasında öğrenme ortamına yönelik tasarım ilkeleri belirlenmiştir. Belirlenen tasarım ilkeleriyle üçüncü döngü gerçekleştirilmiş, uygulama sürecinde elde edilen raporlar ile uygulama sonrasında öğretmen adayları ve ders öğretmenin görüşleri doğrultusunda tasarım ilkeleri revize edilerek son halini almıştır. Araştırmadan elde edilen sonuçlar ışığında tasarım ilkeleri; teknoloji kullanımı, temsil dillerinin kullanımı, ödevler, çalışma yaprakları, öğretmenin rolü ve grup çalışması şeklinde ortaya çıkmıştır. Belirlenen bu tasarım ilkelerine dikkat edilerek oluşturulacak bir öğrenme ortamının öğretmen adaylarının farklı dilleri ayırt etmesine ve kullanmasına, düşünme biçimlerinin gelişimine katkı sağlayacağı ve somutluk, gereklilik ve genellenebilirlik prensiplerinin karşılanmasında yardımcı olacağ düşünülmektedir.

Anahtar Kelimeler: Lineer cebir, vektör uzayları, öğrenme ortamı, tasarım ilkeleri, teknoloji, tasarım tabanlı araştırma

Türkçe sürüm için tıklayınız

\section{Introduction}

Linear algebra is an important study area in mathematics that examines vectors, vector spaces, linear transformations, linear equation systems and matrices. Linear algebra, which is widely used especially in science, has applications in many fields such as anatomy, engineering, information systems, genetics, physics and statistics. The fact that it is a course that offers students the opportunity to make mathematical abstraction is shown among the reasons that make linear algebra important (Harel, 1989a; Kolman \& Hill, 2008). Harel (1989a) stated that it is a necessary course for many curricula, considering that the subjects in linear algebra have the quality to be found in all areas of life as well as in themselves.

Linear algebra can be divided into two main sections, Matrix Algebra and Vector Spaces Theory. Matrix Algebra includes matrices, operations in matrices and their properties, determinants and systems of linear equations and solution methods. Theory of Vector Spaces includes concepts such as vector spaces, subspaces, linear combination, stretching, linear dependence, linear independence, base and dimension. Due to its much more abstract structure, vector spaces theory is the part that students have the most difficulties in linear algebra

Corresponding Author: Gökay Açıkyıldız (D) email: gacikyildiz@biruni.edu.tr

*This study has been produced from the doctoral dissertation of the first author under the supervision of the second author.

Citation Information: Açıkyıldız, G. \& Kösa, T. (2021). Creating design principles of a learning environment for teaching vector spaces. Turkish Journal of Computer and Mathematics Education, 12(1), 244-289. http://doi.org/10.16949/turkbilmat.860627 
course (Dorier, 1995). According to Dorier (1995), the difficulties students have in learning linear algebra are a result of its abstract and formal nature.

When the studies on teaching linear algebra are examined, it is seen that the emphasis is on vector spaces and linear transformations (Britton \& Henderson, 2009; Doğan, 2010; Donevska-Todorova, 2018; Dorier 1998; Dorier, Robert, Robinet \& Rogalski, 2000; Harel, 1987; Klasa, 2009; Sierpinska, Dreyfus \& Hillel, 1999; Stewart \& Thomas, 2010). The reason why the researches on the subject are mostly on the theory of vector spaces is that there are difficulties in learning and teaching because the concepts of vector spaces are abstract by definition. Robert and Robinet (1989) determined the basic criticisms of students towards the lesson as the use of formalism, the existing of many new definitions, and the inability to establish a relationship between previously learned knowledge and new knowledge. Dorier et al. (2000) named this situation "the obstacle of formalism" and stated that in many cases formalism was the cause of student difficulties.

Linear Algebra includes many new concepts and their properties. In this course, students are expected to think and study on concepts in most general situations ( $\mathrm{V}$ vector space, linear transformation classifications, algebraic structures), not in specific situations $\left(\mathrm{R}^{2}, \mathrm{R}^{3}, 2 \times 2\right.$ matrices, ...) (Hillel, 2000). In addition, students are expected to define transformations on these structures and to use different modes of description. According to Hillel (2000), linear algebra concepts have three different definitions and associated modes of description. Hillel (2000) discussed the languages used in linear algebra under three headings as geometric mode, algebraic mode and abstract mode. Vectors, operations on vectors and transformations in each mode have special definitions and notations. For instance, a vector is represented as an arrow in geometric mode, a matrix of rows or columns consisted numbers or symbols in algebraic mode, and an element of a vector space in abstract mode. These modes of description co-exist, are sometimes interchangeable, but are certainly not equivalent (Hillel, 2000). There is a transition consistently from one to the other. Understanding and tracking the transition from one to another is one of the main reasons for difficulty for a student who cannot distinguish between this definition and modes of description. Apart from modes of description, modes of reasoning may be needed for the development of students' understanding of different definition and modes of description in linear algebra.

Sierpinska (2000) aims at identifying the characteristics of the students' way of thinking in linear algebra. She defined three modes coexisting in linear algebra: synthetic-geometric, analytic-arithmetic, and analyticstructural. Sierpinska (2000) stated that there is a need for the development of these three basic modes of thinking. In the synthetic-geometric mode of thinking, while students try to describe the given mathematical objects without definition, in analytical-arithmetic and analytical-structural modes of thinking, students try to understand objects by using their definitions and properties (Sierpinska 2000). These modes of thinking are luculently related to the modes of description that Hillel (2000) defined. The language used in the syntheticgeometric mode of thinking is the geometric language of $\mathrm{R}^{2}$ and $\mathrm{R}^{3}$. While the language used in analyticalarithmetic mode of thinking is the algebraic language of the more specific theory of $\mathrm{IR}^{\mathrm{n}}$, the language used in analytical-structural mode of thinking is the abstract language of general formalized theory (Turğut, 2010). Also, modes of description and the modes of thinking defined by Sierpinska (2000) are not exactly the same. It is possible for a student studying on $\mathrm{IR}^{\mathrm{n}}$ to use synthetic-geometric and analytical-arithmetic thinking modes as well as analytical-structural thinking. Analytical-theoretical thinking is the highest level mode of thinking, and a student who has this mode of thinking can also use the features of other modes of thinking.

Harel (1989a) stated that the main difficulty of students in understanding and using the concepts of linear algebra is due to the introduction of abstract concepts quickly without a solid intuitive basis. Harel (2000) proposed three basic pedagogical principles for linear algebra teaching. These are Concreteness, Necessity and Generalizability principles. Concreteness principle is based on the idea that students can build their understanding of a certain concept in a content that is concrete for them (Harel, 2000). For instance, a student should perceive the concept of function as a mathematical object in order to speak of the concept of derivative in analysis, similarly, should see each polynomial that is an element of this set as an object-vector in order to speak of the concept of linear combination on $\mathrm{P}_{4}(\mathrm{R})$, The necessity principle expresses the active participation of students in linear algebra lesson (Aydin, 2007) and educational activities are important in implementing this principle. Educational activities should present problem situations that are realistic and accepted by students. Making students perceive and see the connections between concepts with a special example or activities can provide basis for the formation of a conceptual understanding and thus the necessity principle is applied. The generalizability principle is related to didactic decisions regarding the selection of teaching materials rather than the learning process (Harel, 2000). A supportive situation is formed for the concreteness principle when teaching is associated with a concrete model, and the instructional activities carried out on this model can provide generalizability of the concept. In this process, activities to meet the concreteness principle can be important. The concrete models used should be organized in a way that allows the students to understand and assimilate abstract concepts (Turğut, 2010). The general concept should be reached with the studies carried out on the model. Generalization may not occur in cases where the model is very specific and its the common point with the general concept is very limited. 
The Linear Algebra Curriculum Study Group (LACSG) which was formed by 16 mathematics educators in the 90s, suggested the adoption of new approaches in linear algebra teaching as a result of their research. The group founded under the leadership of David Carlson, Charles Johnson, David Lay and Duane Porter, aimed to contribute to the development of linear algebra teaching and to attract a solid and sustainable interest in this issue. LACSG's recommendations for teaching linear algebra course are listed by Carlson (1993) as follows.

1. Linear algebra course content should be arranged to meet the needs of different disciplines.

2. Linear algebra should be conducted as a course of at least two semesters.

3. There should not be too much emphasis on proof in the first semester linear algebra lessons.

4. Technology should be used in linear algebra lessons

5. Should make use of geometric representations

6. Course content should be organized as operations in matrices, systems of linear equations and their solution, determinants, linear combination in $\mathrm{R}^{\mathrm{n}}$, linear independence, base, subspaces...

Among the above suggestions, we can say that one of the most remarkable and innovative suggestions according to in that period is the idea of using technology in linear algebra lessons. Mathematics can be difficult for students in subjects have no simple physical or visual representations. Dubinsky (1997) stated that the use of computers can be useful in providing concrete representations for many important mathematical objects and processes. Similarly, the National Council of Teachers of Mathematics stated in its report published in 2000 that the visual power of technological tools can facilitate visualizations that students cannot do alone (NTCM, 2000). In parallel with these suggestions, many researchers emphasized that technology support is very important in linear algebra teaching (Aydın, 2009b; Dikovic, 2007; Dorier, 2002; Harel 2000; Pecuch-Herrero, 2000; Wu, 2004) and many different softwares have been recommended by researchers. In the last decade, software that includes the features of both computer algebra systems (CAS) and dynamic geometry software (DGS) has emerged. One of the remarkable among these software is the dynamic mathematics software GeoGebra. GeoGebra creates two components for each object. The algebraic component reflects the equation of the object in open, closed or parametric form, while the geometric component reflects the graphical representation of the object. Both representations of an object can be intervened by the user in the GeoGebra software (Çekmez, 2013). Matematiksel kavramlara ait hem cebirsel temsilleri hem de grafik gösterimlerini bir arada sunan GeoGebra, bu özelliği sayesinde üst düzey soyut matematik kavramların öğretiminde de etkili bir araç olarak kullanılabilir (Hohenwarter ve Jones, 2007).

In addition to having an abstract structure, we can say that linear algebra is a course that includes different definitions and representations along with different modes of description. It is seen that two types of approaches are used when looking at the structure of the linear algebra course content. These approaches are named as Bourbaki style and new approach. Textbooks with Bourbaki style were prepared by following a way from the general to the specific (Hillel, 2000). In Bourbaki style, the linear algebra course is first introduced with the theory of vector spaces and then continued with the more specific theory in $\mathrm{R}^{\mathrm{n}}$. Especially with the early $1980 \mathrm{~s}$, many educators and textbook writers abandoned the Bourbaki approach and started to adopt the new approach. To construct intuitive understandings to linear algebra course with the new approach; it is made a beginning in a geometric form, then the algebraic and abstract representations of the concepts in the vector space $R^{2}, R^{3}, R^{n}$ and $\mathrm{V}$ can be included. However, the new approach adopted was not very effective in strengthening students' understanding of vector space theory in traditional teaching-based classroom environments (Dogan, 2001; Hillel \& Sierpinska, 1994). Therefore, students' deeper understanding of vector space concepts may depend on the design of technology-supported and student-centered learning environments.

There are many studies on linear algebra teaching in the literature. Hristovitch (2001) stated that the metaphors and analogies that students chose led them to misconceptions about linear independence. Intuitional inferences have been effective here. Bogomolny (2006) and Hristovitch (2001) discussed how students develop conceptual understanding. Çelik (2015) and Doğan-Dunlap (2010) aimed to investigate students' modes of thinking about the concept of linear independence. Çelik (2015) investigated undergraduate students 'understanding of the concepts of linear dependence / independence and students' modes of thinking regarding these concepts. She found that students mostly used arithmetic or algebraic operations in solving the given problems. Nardi (1997) and Stewart \& Thomas (2010) examined the cognitive development of students in relation to the concept of base by taking into account the structure in which the base concept was given after the concepts of span and linear independence. Stewart and Thomas (2010) emphasized the importance of the concept of linear combination and stated that more time should be devoted to the teaching of the concept of linear combination in linear algebra courses due to its close relationship with both span and linear independence concepts. Donevska-Todorova (2018) researched how a technology-enhanced learning environment can contribute to the development of students' competencies. She suggested that a model in which modes of description and thinking are intertwined is appropriate for the design of learning and teaching environments.

Consequently, (i) the abstract and theoretical nature of vector space theory (Dorier et al., 1995), (ii) the multiplicity of new definitions (Dorier et al.2000; Hillel, 2000), (iii) the obstacle of formalism (Dorier, 2000), 
(iv) deficiencies of students regarding set theory, logic, and proof (Britton \& Henderson, 2009; Dorier, 2000; Hillel, 2000), (v) careless use of existing modes of description (Hillel, 2000), (vi) using geometric representations restrictedly or in a way that causes misinterpretation (Nardi, 1997; Sierpinska, 2000) and (vii) asking students to think and study on concepts and related procedures in the most general situations (Sierpinska, 2000) are the main difficulties encountered in teaching and learning linear algebra. By taking into consideration the suggestions made to overcome these difficulties, there is a need to design a technology-aided enriched learning environment that uses visualization techniques and geometric representations that allow students to make abstractions, stimulate different modes of thinking and include in-class presentations and activities that will carry students to a higher mode of thinking. In this context, the study aimed to determine the design principles of a technology-supported learning environment for the teaching of vector spaces by considering the modes of description defined by Hillel (2000), Harel's (2000) pedagogical principles and Sierpinska's (2000) modes of thinking. In accordance with this purpose. the research problem determined as; "How should the design principles of learning environments to be created for effective teaching of vector space concept?"

\section{Method}

The study was conducted with a design-based research method. Design-based research is defined as a systematic and flexible research method in which analysis, design, development and application processes are carried out cyclically, in order to develop educational practices, design principles and theories in a real application environment in cooperation with researchers and participants (Wang \& Hannafin, 2005). Designbased research (DBR) differ from the other design research methods since the design - analysis - redesign phases effectively include a cyclical process (Kuzu, Çankaya, \& Misırl1, 2011; Herrington, McKenney, Reeves, \& Oliver, 2007), and participants and researchers take an active role from the beginning to the end of the process. In addition, DBRs are studies in which all regulations and changes made during the process are reported in detail (Reeves, 2000). In this study, design-based research was carried out in three cycles in determining the design principles of the learning environment.

\subsection{The Design and the Implementation of the Research}

In the study, the design - implementation - development and evaluation phases were carried out in three cycles and the changes made in each cycle were reported in detail. Thus, by reviewing the data obtained from each cycle, arrangements were made to realize more successful cycles and a more efficient design was tried to be created. In Figure 1, the application steps in design-based research are shown as a flow chart.

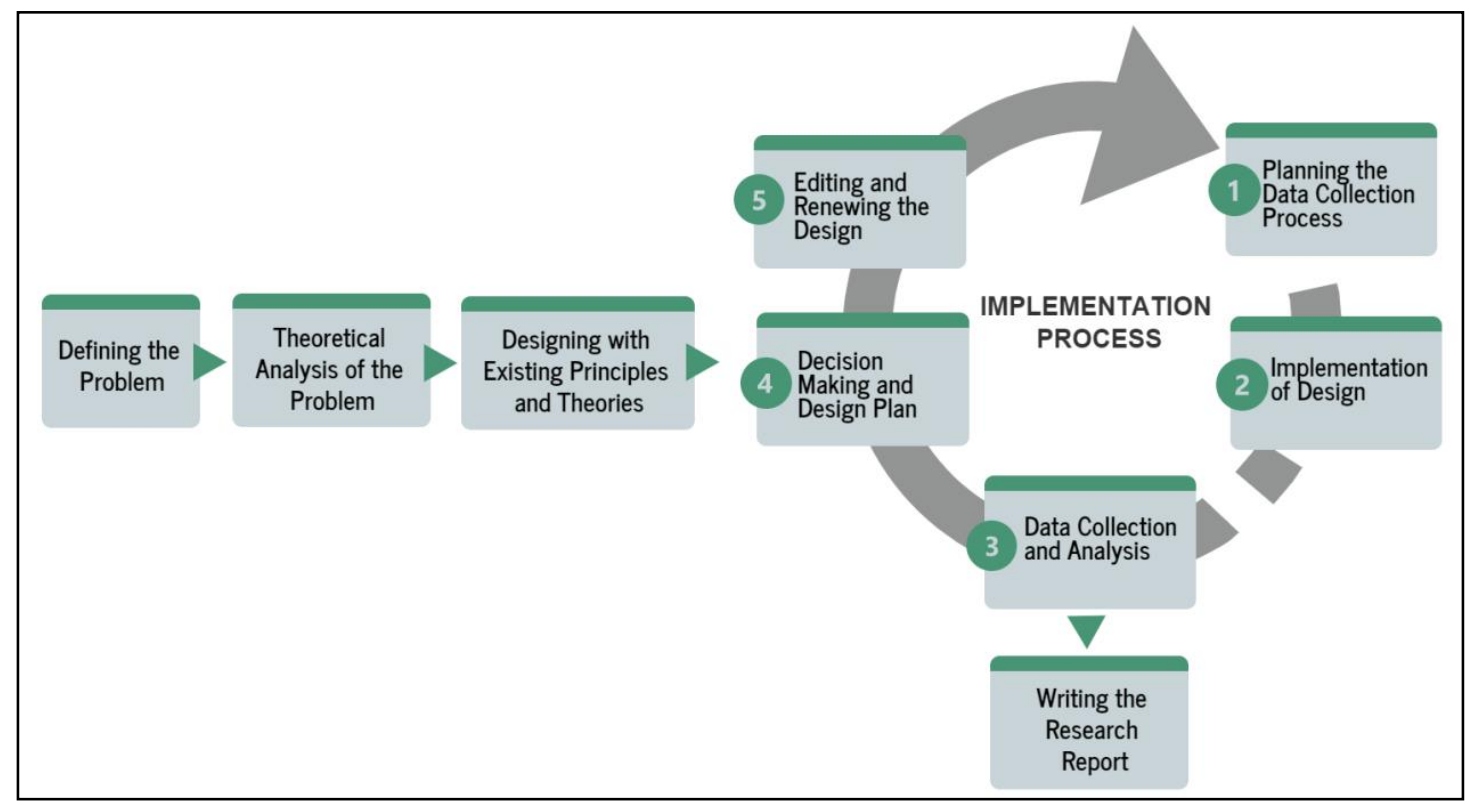

Figure 1. DBR Application Steps (Kuzu et al., 2011)

Each step given in the application process in Figure 1 was repeated in all cycles where DBR was applied. After the literature review on the subject, the learning environment was designed by considering the suggestions for learning-teaching difficulties about vector spaces and in line with the principles set forth with the conceptual framework. Basic components of the learning environment consist of three parts which are worksheets and group work, GeoGebra templates and assignments. In order to apply the designed learning environment in a real classroom environment, a 6-week implementation plan has been created on the subject of vector spaces. Learning outcomes for teaching each concept related to vector spaces have been created and lesson plans have 
been prepared for outcomes. Worksheets, assignments and GeoGebra templates were prepared while preparing the lesson plans. Figure 2 shows the flow chart of the study each cycle of which lasts six weeks.

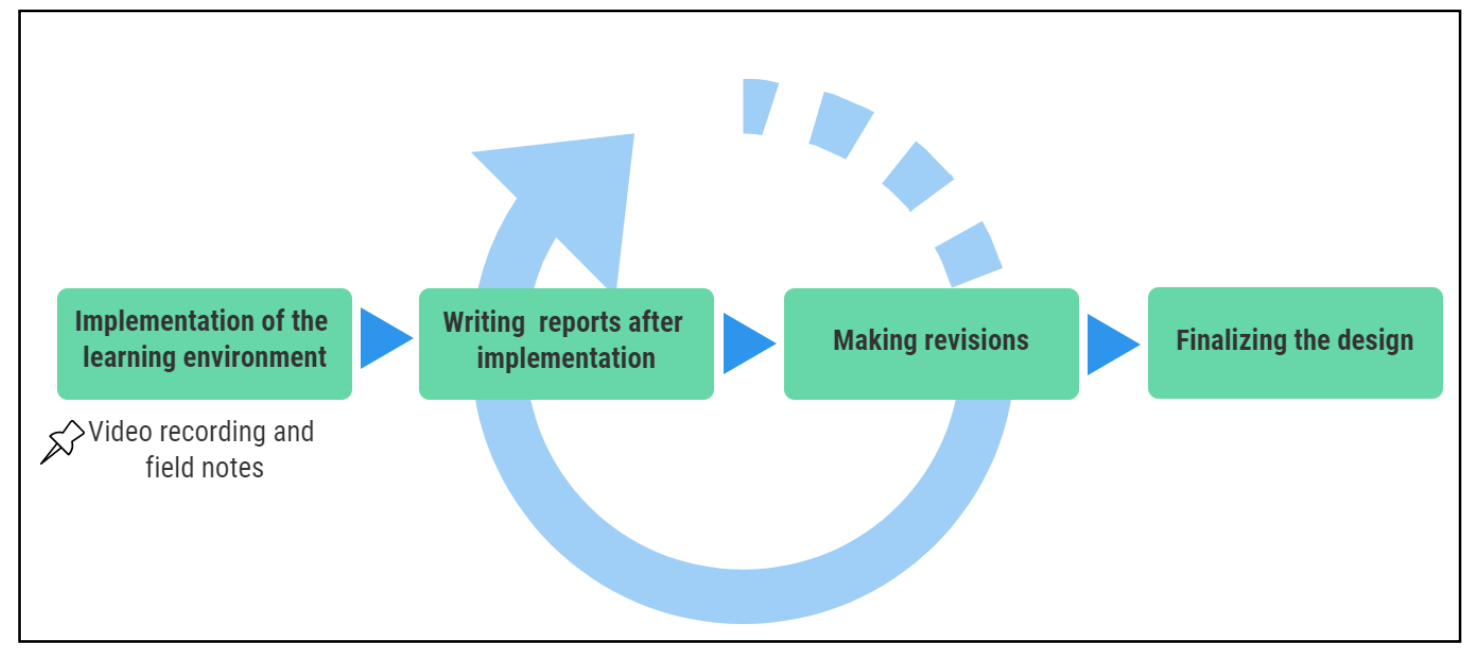

Figure 2. Conducting the research

Figure 2 shows how the research was conducted over a period of one week and the procedures took six weeks. As can be seen in Figure 2, reflection reports were kept right after the course in which the learning environment was applied, and then revisions were made on the data obtained from these reports, video records and field notes. These revisions can be listed as removing unnecessary questions in the worksheets, correcting the instructions, making the questions more understandable, developing GeoGebra templates to making them suitable for a more practical and theoretical background, and organizing in-class presentations. After the revisions were made, the researcher, together with expert educators in the field, evaluated the revisions and finalized the design for the next cycle. The same process was used for each course for 6 weeks, and the design principles were determined after two cycles and the research was made ready before the third cycle. The list of the subjects covered during the 6-week course is presented in the table below.

Table 1. The List of Subjects Taught in the Classes

\begin{tabular}{cc}
\hline Week & Subjects \\
\hline 1. & Vector Space \\
\hline 2. & Subspace \\
\hline 3. & Linear Combination \\
\hline 4. & Span \\
\hline 5. & Linear Dependence / Independence \\
\hline 6. & Base-Dimension \\
\hline
\end{tabular}

Each subject in Table 1 was applied for 4 class hours per week and the classes were mostly conducted in the laboratory environment.

\subsection{Participants}

The study was conducted with students in a secondary and primary school mathematics teaching program at a state university. Study groups consisted of a different number of students in each cycle. The number of students in the cycles and the dates of the study are given in the table below.

Table 2. Study Group

\begin{tabular}{ccccc}
\hline Cycles & $\begin{array}{c}\text { Number of } \\
\text { Students }\end{array}$ & Date & Department & University \\
\hline $1^{\text {st }}$ Cycle & 51 & $\begin{array}{l}2016 / 2017 \text { Spring } \\
\text { Semester }\end{array}$ & $\begin{array}{c}\text { Primary School } \\
\text { MathematicsTeac } \\
\text { hing }\end{array}$ & $\begin{array}{c}\text { Karadeniz Technical } \\
\text { University }\end{array}$ \\
\hline $2^{\text {nd }}$ Cycle & 44 & $\begin{array}{l}2016 / 2017 \text { Spring } \\
\text { Semester }\end{array}$ & $\begin{array}{c}\text { Primary School } \\
\text { MathematicsTeac } \\
\text { hing }\end{array}$ & $\begin{array}{c}\text { Karadeniz Technical } \\
\text { University }\end{array}$ \\
\hline $3^{\text {rd }}$ Cycle & 11 & $\begin{array}{l}2017 / 2018 \text { Spring } \\
\text { Semester }\end{array}$ & $\begin{array}{c}\text { Secondary School } \\
\text { MathematicsTeac } \\
\text { hing }\end{array}$ & $\begin{array}{c}\text { Karadeniz Technical } \\
\text { University }\end{array}$ \\
\hline
\end{tabular}


The study groups of the first and second cycles consist of second year students of 51 and 44 students who take linear algebra course. The lessons were taught in these classrooms with one week intervals. The learning environment designed for teaching vector spaces was implemented in a 51-person classroom as the first cycle. During the practices, the classes were videotaped and field notes were kept at the same time. Some revisions were made by watching the video recordings repeatedly and by using field notes. The new design, which was created a week later through the revisions made, was applied in a classroom including 44 people. The design was implemented in this way in both classes over a six-week period. The third cycle of the study was conducted at the same university the following year with 11 second grade students who are enrolled in the department of mathematics teaching and who take the linear algebra course. There is no difference between the linear algebra course contents of primary and secondary mathematics teaching programs.

\subsection{Data Collection Tools and Data Analysis}

The research data were obtained from video recordings and field notes. Field notes are used as the primary recording tool in qualitative research. These notes are a place full of information about people, events, activities and conversations. In these notes, we have records regarding thoughts, intuitions and emerging patterns and we can observe the researcher's investigations as well as individual reactions (Glesne, 2012; Y1ldırım \& Şimşek, 2005).

Field notes were taken in the observations in the classroom environment by the researcher and the lecturer. In the field notes, the observation data and comments about the process were included by the researcher and the lecturer. Both the problems that arise in the designed learning environment and the difficulties students experience and the parts they do not understand during the process were reported with field notes. Thus, it is aimed to improve the design by making the necessary changes and arrangements required with the help of field notes after each cycle. In addition, video recordings were made during each class. The video recordings were archived to the computer and external memory after deleting the dates of the recorded days every week and watched for the arrangements to be made in the next cycle during the application process or at times after the application.

Within the scope of the research, the observation data obtained with the help of field notes kept by the lecturer and the researcher were carefully reviewed after each application, transcribed and turned into a report. With the help of detailed reports, it is aimed to organize the design in each cycle and make changes where necessary. The video recordings were watched after the applications and other times when necessary, so the process was followed up and used in the analysis of the field notes. The analyzes were carried out in line with the theoretical framework of the research to meet the pedagogical principles for linear algebra teaching, pay attention to the use of representation languages and contribute to the development of thinking modes. In this way, the stories of the applications performed at the end of each cycle were created and the revisions to be made for the next cycle in line with these stories were tried to be presented in general terms.

\section{Findings}

In this section, the findings obtained as a result of the application of the learning environment designed for the teaching of vector spaces in two cycles are discussed under the titles of study story and revisions. Findings for each cycle are presented separately. The findings for the first two cycles, along with the results obtained in the analysis of field notes and video recordings, and the regulations and changes decided to be made in the first and second cycles are presented in this section.

\subsection{First Cycle Design Study}

\subsubsection{Study Story}

The first cycle of the study was conducted with 51 students enrolled in a state university's primary school mathematics teaching program and taking linear algebra in the spring semester of the 2016-2017 academic year. The application covers the basic concepts of vector space, subspace, linear combination, span, linear dependence, linear independence, base and dimension. Before starting the applications for the first cycle, GeoGebra software was introduced to the students during a two-hour lesson. During this two-hour lesson, the main functions of the GeoGebra software were demonstrated, and especially the sections to be used in the lesson were emphasized. Since the students have already taken courses on the GeoGebra software, the two-hour application requirements were met with two hours of practice. In the first cycle, some of the lessons were conducted in the classroom environment, while some were held in the laboratory environment. The activities were implemented in groups of two with students in the laboratory lessons. During the course, the students were asked to fill in the worksheets interactively with the GeoGebra software. During the application, two homework were given to students in each lesson. During the 6-week process, all the lessons were videotaped and reflection reports were written by the researcher after each lesson. Taking into account the video recordings, reflection reports and the observations of the researcher, arrangements have been made in worksheets, GeoGebra 
templates, homework and in-class presentations in order to eliminate the problems that may arise in terms of the use of modes of description, the development of modes of thinking and understanding of practice questions

\subsubsection{Program Revision For the First Cycle}

In this section, revisions related to the learning environment designed after the first cycle are given separately under the titles of the concepts covered.

Vectors, Vector Sum and Scalar Product $\left(R^{2}\right.$ and $\left.R^{3}\right)$

The worksheets prepared for teaching the concepts of vectors, vector sum and scalar multiplication consist of two parts. In the first part, vectors in the plane, vector family, position vector and representation of vectors, in the second part, vector sum and scalar product concepts are discussed.

No changes were made in the second part. In the first part, some changes were made in both the worksheet and the GeoGebra template. In the first part of the activity, students were given a ready-made GeoGebra template and asked to create geometric shapes by ticking the checkboxes on this template. However, in this part, it was thought that it would be more beneficial for students to create geometric structures through the program instead of the ready-made template, and changes were made in this direction. Although the GeoGebra course was given to students before, it was thought that students' own creation of the geometric structures would allow them to study the program more and focus on exploration. Because it was observed that students had difficulty in creating vectors in GeoGebra templates for other concepts and they constantly wanted to get help from the researcher. It is important for students to create geometric structures themselves in order to have practical experience throughout the topic of vector spaces, since vector drawings will be used frequently in $R^{2}$ and $R^{3}$. The instruction of the first question was revised and changed depending this change in the Geogebra template. Figure 3 shows the changes made in the first two questions of the worksheet regarding the concept of vector.

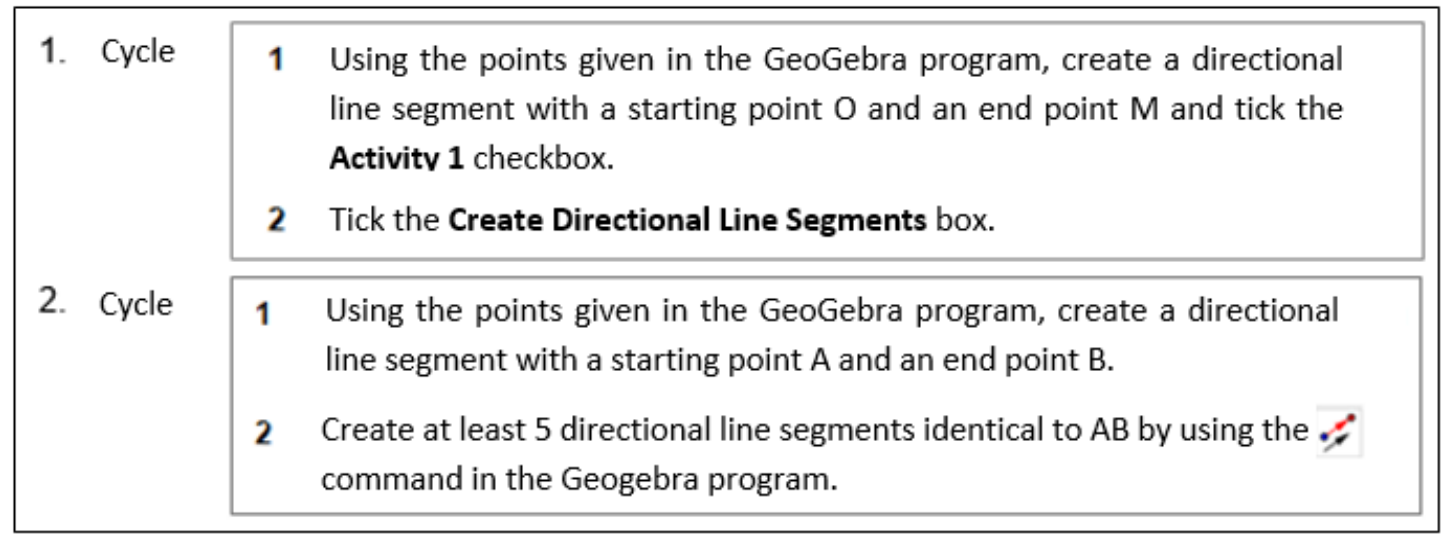

Figure 3. The change in Activity 1 after the first cycle

As seen in Figure 3, the instructions on the worksheet in the first cycle are arranged as shown in the second cycle. In addition, in the option c of the second question, it was observed that the students had some difficulty in understanding during the implementation. In the option $\mathrm{c}$ of the second question, the students were asked whether it is possible to match the vector family on the screen with a single point and some students stated that they did not understand this expression. The researcher summarized this situation in the field note as follows.

"Although the questions were generally understood by the students, a few students stated that they did not fully understand the option $\mathrm{c}$ of the second question, and the researcher helped the students to understand the problem by making the necessary explanations. A vector was given from $R^{2}$ and $R^{3}$ respectively in the fourth and fifth questions of Activity 2 and the students were asked to create sliders in the Geogebra software."

In this section, it is aimed to express vectors algebraically from their geometric representation and to bring students to an analytical-arithmetic thinking structure. For this purpose, the students were guided to see the vector-point relationship by showing the position vector representing the vector family and its coordinates. Although there was no change in the worksheet for option $\mathrm{c}$ of the second question, it was decided to make the necessary explanations to the students in the next cycle by taking notes.

\section{Vector Space and Subspace}

The implementation prepared for teaching the concepts of vector space and subspace consists of two parts named Activity 1 and Activity 2. vector space and subspace concepts are discussed in first and second part respectively. 
In general, it was not made change in the worksheets. Only in Activity 1, the first question which consists of four options a, b, c and d was combined. Similarly, options a and b of the second question were combined. It was observed that students had difficulties in ensuring content integrity while reading the questions. The researcher summarized this situation in the field note as follows.

"Some questions that consist of a few options was understood by the students as if they were different questions. When I asked students what the problem is, a student asked a question as follows; "Teacher, will we create them separately or we do it on a single figure?. Then, looking at the situation of other students in the class, I saw that they encountered a similar situation and tried to decide what to do."

A change was made to ensure the integrity of the questions and get rid of these negativities. The revision made in the first question of the subspace activity is given in Figure 4 below.

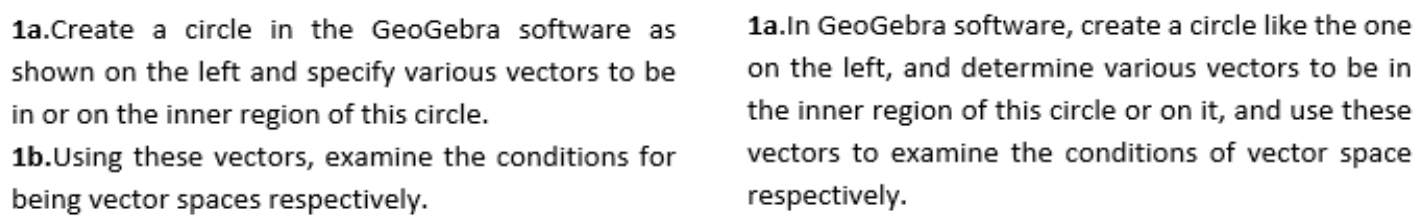

1a.In GeoGebra software, create a circle like the one on the left, and determine various vectors to be in the inner region of this circle or on it, and use these vectors to examine the conditions of vector space respectively.

Figure 4. Revision in the first question of subspace activity

Similar to Figure 4, the second question of the activity was revised by making changes. No other change was made in the questions in the activities, but although the questions were understood by the students, the activity took longer than the planned time. It was observed and reported that the students lost time in creating the geometric structures which they were asked to draw especially in the first two questions. However, no changes were made regarding the GeoGebra template and it was decided to be re-evaluated in case of a similar situation in the second cycle.

\section{Linear Combination and Span}

The implementation prepared for teaching the concepts of linear combination and span consists of four parts: Activity 1, Activity 2, Activity 3 and Activity 4. The first three activities were prepared for the teaching of the concept of linear combination and the last activity for the concept of span.

The most important issues that draw attention in the implementation of this activity have emerged as time problem and loss of motivation. The fact that different vectors and different situations related to these vectors were involved in the activity caused the number of questions to be high, and in this case, the time allocated for the activity increased. Although the students generally did not have difficulties in understanding and solving the questions in the activity, the prolongation of the time caused their motivation to decrease. The researcher summarized this situation in the field note as follows.

\footnotetext{
"In this part of the activity, it was observed that the students were more interested in the questions posed algebraically and that they mostly found correct solutions. However, it was observed that some students could not fully match the worksheet and the Geogebra template. In addition, the long duration of the activity and the crowded classroom caused a decrease in motivation of the students. It was observed that it took time for some students to create the set of linear combinations of the vectors given in the worksheet and they had difficulty understanding the questions posed about the GeoGebra."
}

The concepts of linear combination and span are interrelated concepts. Therefore, it should be processed by handling as a whole. In this respect, simplifications and rearrangements were made to maintain the integrity of the activity.

In the next section, no changes were made regarding the questions in activities. However, in order to be more understandable and fluent, Activity 2 and Activity 3 were divided into four parts by taking into account the different situations they have. In Activity 2, it was focused on cases involving a single vector in the plane and two vectors such that one of them is a scalar multiple of the other. In Activity 3, it was focused on the cases involving two different vectors in the plane and three vectors that can be written as a linear combination of each other. The revisions made are given below.

1. Activity 1 , single vector and linear combinations

2. Activity 2 , two vectors such that one of them is a scalar multiple of the other and their linear combinations

3. Activity 3, two different (one not a scalar multiple of the other) vectors and their linear combinations

4. Activity 4, three vectors that can be written as a linear combination of each other and their linear combinations 
The questions in the activities included geometric and algebraic representations of vectors in different situations. Thus, it is aimed that students can observe the differences between different representations of concepts and use them correctly. Considering the video recordings and the researcher's field notes, it was thought that geometric and algebraic representations should be presented clearly and fluently in order to understand the concepts of linear combination and span in the most abstract form.

The GeoGebra template, which was prepared for teaching the concepts of linear combination and span, was mostly prepared in a way that the students would create the geometric structures themselves. In case of continuing problems with time and motivation in the first cycle, it was decided to review the GeoGebra template and to design a template that could make the activities more fluent. The researcher summarized this situation in the field note as follows.

"During the activity, it was observed that the students gave correct answers when they handled the questions from algebraic and geometrical perspectives, but they did not justify their geometric approaches. It can be said that the reason for this is that students mostly prefer to give algebraic answers to the questions and use the Geogebra software only for control purposes. In order to overcome these problems, it was considered to simplify the activity a little more and to make the Geogebra template more simple by revising it."

\section{Linear Dependence/Independence}

The application prepared for teaching the concepts of linear dependence and independence consists of a single part. It was observed that the implementation of the activity as a whole made it difficult to understand the activity and caused the students to get bored from time to time during the application. Another factor affecting this situation can be show as the lack of a ready-made GeoGebra template for activity. The students were not given a ready-made template, instead they were asked to create the geometric structures they needed using the GeoGebra software. However, many students did not prefer to use the software, and thus it became a worksheet focused activity. For this reason, especially in the first part of the activity, it didn not occur learning from concrete to abstract, and the direct abstraction of the students who did not use the software made it difficult to make assumptions about the questions. The researcher summarized this situation in the field note as follows.

"It was thought to develop the GeoGebra template and the activity was divided into three parts to be more understandable."

Considering both the researcher's field notes and the conversations between the students in the video recordings, it was decided to divide the activity, which consists of a single part, into three parts. These parts;

1. Activity 1 , determining necessary and sufficient conditions for linear independence of vector sets containing different numbers of vectors

2. Activity 2, which includes true / false questions about linear independence.

3. Activity 3, where the linear independence of vectors is examined based on their geometric representation.

Thus, it is aimed to implement each activity separately and to make it more understandable. However, there were changes and additions to the questions in the activities.

While changing about the third and fourth questions in Activity 1, firstly the examples in which the linear independence of binary and triple vector sets will be examined were determined. Then, the assumptions of the students regarding the necessary and sufficient condition for the linear independence of the vector sets given through these examples were asked. The changes in the third question are given in the figure below.

\begin{tabular}{|c|c|}
\hline 1. Cycle & $\begin{array}{l}\text { 3. Similar to the second question, investigate whether you can produce an assumption about the } \\
\text { necessary and sufficient conditions for the two vectors to be linearly independent in } \mathrm{R}^{3} \text { based } \\
\text { on your own experience and observations. Explain your results with justification. }\end{array}$ \\
\hline 2. Cycle & $\begin{array}{l}\text { 3. Consider } u=(1,-3,2), v=(0,5,2), w=(-8,12,-4), z=(3,-9,6) \text { ve } t=(2,-3,1) \text { vectors in } R^{3} \\
\text { Create each of these vectors in GeoGebra program. } \\
\text { 4. Now examine the linear independence of each of the } \\
\{u, v\},\{u, w\},\{u, z\},\{u, t\},\{v, w\},\{v, z\},\{v, t\},\{w, z\},\{w, t\} \text { ve }\{z, t\} \text { sets. } \\
\text { Try to make an assumption about the necessary and sufficient conditions for the two vectors } \\
\text { to be linearly independent in } R^{3} \text { based on your own experience and observations. Explain your } \\
\text { results with justification. }\end{array}$ \\
\hline
\end{tabular}

Figure 5. The revision made in third question 
As can be seen in Figure 5, after the changes mentioned above, the question arranged to take place in the second cycle. As can be seen, instead of directly asking students' opinions about the linear independence of the two vectors, previously determined vectors were given and questions were asked to the students over binary vector sets consisting of these vectors. The researcher summarized this situation in the field note as follows.

"In the third question of activity, It was observed that students try to reach the necessary and sufficient conditions by studying with examples such as $(1,1,1),(2,2,2)$ generally or they studied with vectors such as $(1,2,3),(5,7$, 8) which were as different as possible from each other. Although it seems to be understood when vectors are linearly dependent and when they are linearly independent, in this part, students could not make a clear assumption about the concept of linear independence. In the fourth question of the activity, it was observed that some students were bored with the activity in the part related to the linear independence of three vectors in $\mathrm{R}^{3}$. In this activity, the students were not given a ready-made template related to the Geogebra software and the students were asked to use the software for the vectors they determined. However, it was observed that many students tried to answer the questions without using the software, so they did not use a geometric approach to the questions."

Based on the researcher's field notes, arbitrary use of the software was become a necessity in this section. With the changes made, it is aimed to contribute to the development of students' modes of thinking by using different representations and by presenting concrete content more effectively. According to these changes made in the questions, a GeoGebra template containing the given vector sets was prepared. It is aimed for students to quickly create vectors using this GeoGebra template and complete the activity. Below is an image of the GeoGebra template.

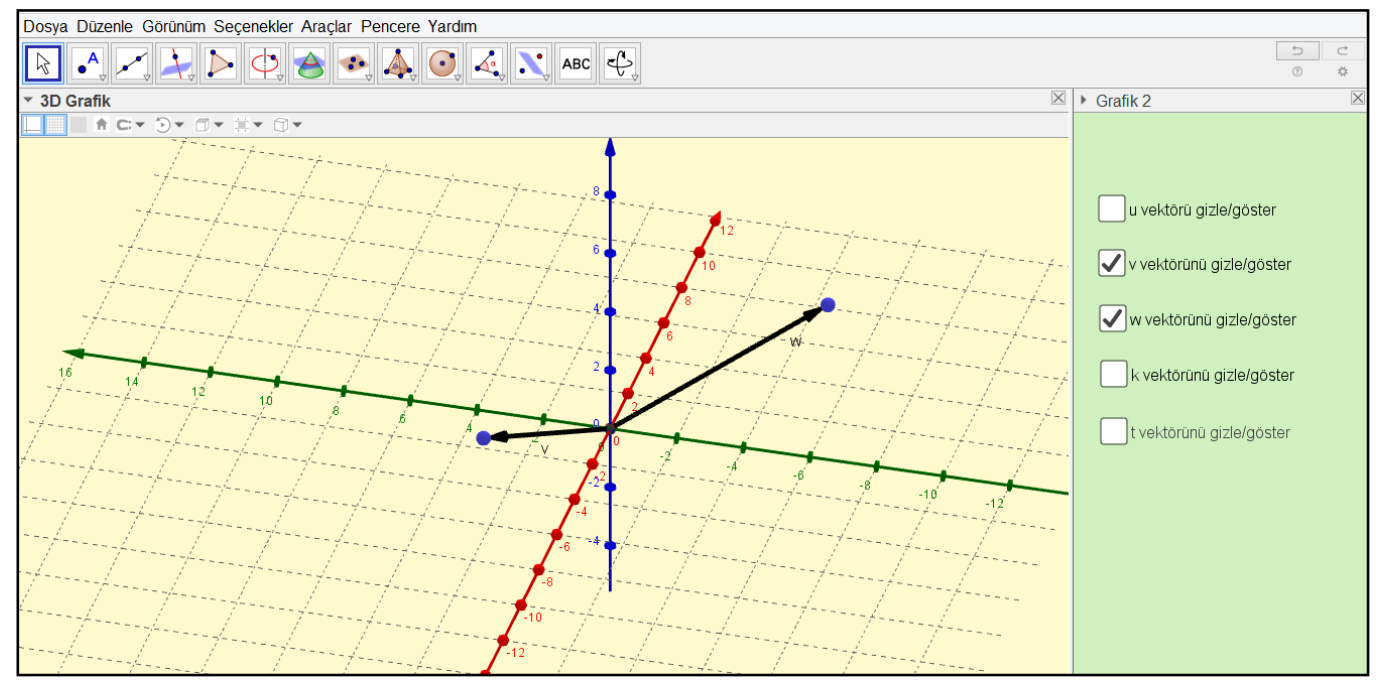

Figure 6. Designed GeoGebra template

As seen in Figure 6, it is aimed for students to quickly create the vectors they want by checking the check boxes on the right side of the screen.

The part containing the right / wrong questions about linear independence is organized as Activity 2. From the suggestion of an mathematics expert educator who attended the linear algebra course, it was decided to add one more question to make the subject more inclusive, and the question "Every set including zero vector is linear dependent" was added. In Activity 1, there was a set containing the zero vector and the students algebraically checked the linear dependence / independence of this set. Adding a question regarding the linear independence of this set was thought to be important to to know what students thought on the issue. Thus, it is aimed to reveal how students think in the most general form about a situation in which they develop algebraically solutions. No change was made in the questions considered in Activity 3, but some additions were included. Parallel to the changes made in Activity 1, geometric representations of vectors in $\mathrm{R}^{3}$ are included in this section, thus giving students the opportunity to better understand the relationship between geometric representations of vectors in $\mathrm{R}^{2}$ and $\mathrm{R}^{3}$ and their linear independence. Also, with the additions to Activity 3, it was aimed to prevent the restricted learning that may arise from including only concrete representations in $\mathrm{R}^{2}$. Geometric representations of the vectors added to Activity 3 are given below. 


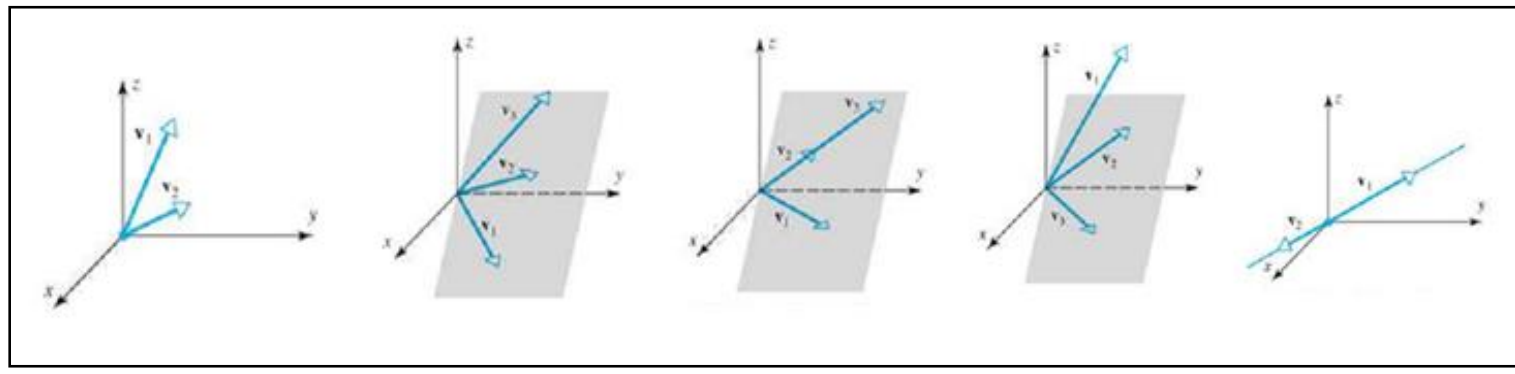

Figure 7. Geometric representations added to the linear dependence / independence activity

With these changes and additions made as seen in Figure 7, the linear dependence / independence activity was arranged for the second cycle. The reason for this arrangement is given below in the researcher's field note.

"It was observed that students gave correct and incorrect answers to the questions in this section. Some students misinterpreted the linear independence of three vectors in $\mathrm{R}^{2}$ geometrically, and some students confused the vectors in $\mathrm{R}^{2}$ and $\mathrm{R}^{3}$ with each other. Therefore, it was deemed appropriate to add vectors in $\mathrm{R}^{3}$ to the activity in order for the students to understand the difference and see the relationships in every situation."

\section{Base and Dimension}

The implementation prepared for teaching base and dimension concepts consists of two parts as Activity 1 and Activity 2. The first activity was prepared for the teaching of the base concept and the second activity was prepared for teaching both base and dimension concepts. In Activity 1, three vector sets consisting of the elements of $R^{2}$ are given and it is aimed to investigate whether these vector sets are a base of the $R^{2}$ vector space. In addition, the students were asked to draw the given vector sets using the GeoGebra software.

There was no part about the questions in Activity 1 that the students did not understand. However, a problem was encountered regarding the scope of the questions in the activity. The researcher summarized this situation in the field note as follows.

"Later on the activity, the students had difficulty in making inferences about the base and the dimension concepts. It was effective in this case that the given sets do not contain all possible cases for the bases of the $\mathrm{R}^{2}$ vector space. It was concluded that students only learn through certain situations."

Based on the field notes, the worksheet has been arranged to meet many different situations in terms of the development of students' analytical-arithmetic mode of thinking. Therefore, the number of sets given in the first question was increased from three to five and added other possible cases to the question. Below is the change made in the first question of activity 1.

1. Cycle $\begin{aligned} & \text { 1) Open the file named Taban1 from your computer. Mark the vector sets given below in the } \\ & \text { program and show them separately. Examine whether the vector sets are bases of the } R^{2} \text { vector } \\ & \text { space. } \\ & \text { A }=\{(1,2),(2,4)\} \quad B=\{(1,1),(-2,3)\} \quad C=\{(2,5),(0,0)\}\end{aligned}$
2. Cycle $\quad \begin{aligned} & \text { 1) Open the file named Taban1 from your computer. Mark the vector sets given below in the } \\ & \text { program and show them separately. Examine whether the vector sets are bases of the } R^{2} \text { vector } \\ & \text { space. } \\ & A=\{(1,2)\} \quad B=\{(1,2),(2,4)\} \quad C=\{(1,1),(-2,3)\} \quad D=\{(2,5),(0,0)\} \quad E=\{(1,2),(-2,3),(2,1)\}\end{aligned}$

Figure 8. The revision made in first question

As seen in Figure 8, all possible situations are included by adding two more vector sets consisting of a single element and three elements.

\subsection{First Cycle Desing Study}

\subsubsection{Study Story}

The second cycle of the study was conducted with 44 students enrolled in a state university's primary school mathematics teaching program and taking linear algebra in the spring semester of the 2016-2017 academic year. The application covers the basic concepts of vector space, subspace, linear combination, span, linear dependence, linear independence, base and dimension as in the first cycle. In the second cycle, lessons were 
conducted one week after from the first cycle. In the second cycle, similar steps to the first cycle were followed in general. Before starting the applications for the first cycle, GeoGebra software was introduced to the students during a two-hour lesson. During this two-hour lesson, the main functions of the GeoGebra software were demonstrated, and especially the sections to be used in the lesson were emphasized. Since the students have already taken courses on the GeoGebra software, the two-hour application requirements were met with two hours of practice. In the first cycle, some of the lessons were conducted in the classroom environment, while some were held in the laboratory environment. The activities were implemented in groups of two with estudents in the laboratory lessons. During the course, the students were asked to fill in the worksheets interactively with the GeoGebra software. During the application, two homework were given to students in each lesson as in the first cycle. During the 6-week process, all the lessons were videotaped and reflection reports were written by the researcher after each lesson. Taking into account the video recordings, reflection reports and the observations of the researcher, arrangements have been made in worksheets, GeoGebra templates, homework and in-class presentations in order to eliminate the problems that may arise in terms of the use of modes of description, the development of modes of thinking and understanding of practice questions.

\subsubsection{Program Revision for the Second Cycle}

In this section, revisions related to the learning environment designed after the second cycle are given separately under the titles of the concepts covered.

Vectors, Vector Sum and Scalar Product $\left(R^{2}\right.$ and $\left.R^{3}\right)$

The activity, which includes the concepts of vectors, vector sum and multiplication with scalar, is divided into three parts in order to arrange both formalistically and focusing on each topic separately. Below is the revisions made in the worksheets.

1.Vectors, worksheet 1

2.Vector sum, worksheet 2

3.Multiplication with scalar, worksheet 3

A worksheet was prepared for each subject, and it was tried to be made more understandable and to ameliorate the page layout formalistically. Apart from this, no changes were made in the parts containing the concepts of vectors and vector sum. In this section, the way of asking some questions and instructions were changed in order to be simpler and clearer. In addition, the toolbar of the GeoGebra template was customized and only the features that will be used by the students during the activity were included in toolbar. The researcher summarized this situation in the field note as follows.

"While I was walking around the desks in the classroom, I noticed that some students tried to draw figures off topic and they got off the point. I observed that some students lost time using features that they don't need in the toolbar for activity. It would be appropriate to edit GeoGebra templates to avoid both situations."

Findings supporting this view of the researcher were obtained from the video recordings as well. Based on these findings, it was aimed to prevent students from wasting time with other features that are not related to the subject in the toolbar. In the figure below, the toolbar used in the 1st and 2nd cycles and the toolbar used in the 3rd cycle is given respectively.

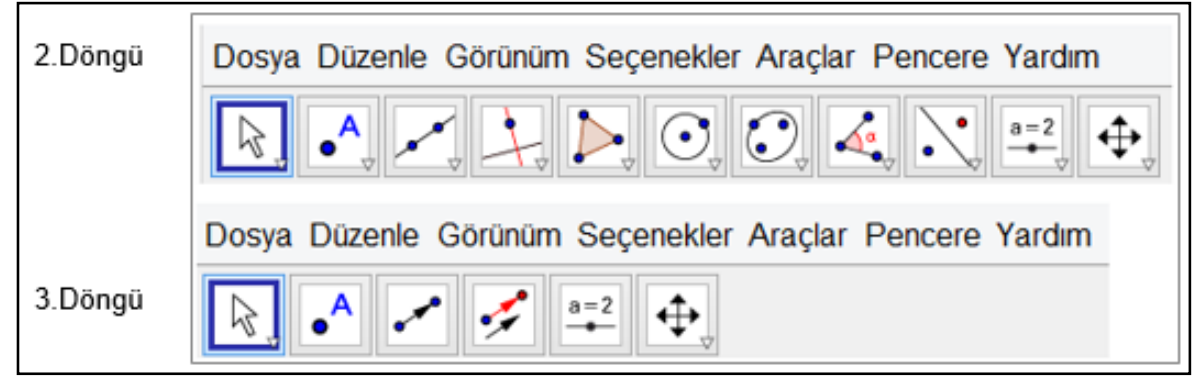

Figure 9. The revision made to the Geogebra toolbar

Unlike the changes made in Figure 9, it was decided to add a question by removing a question in worksheet 2. In this part, a vector from $\mathrm{R}^{2}$ was given to students. Later, the students were asked to multiply this vector by a c real number scalar and examine it with the using GeoGebra template. Then the following question was included to worksheet. 
4) $u=(2,-1,3)$ ve $v=(3,1,2) \quad u$ and $v$ are vectors, $c_{1}$ and $c_{2}$ are real numbers

What are the common properties of all vectors obtained as $c_{1} \cdot u+c_{2} \cdot v$

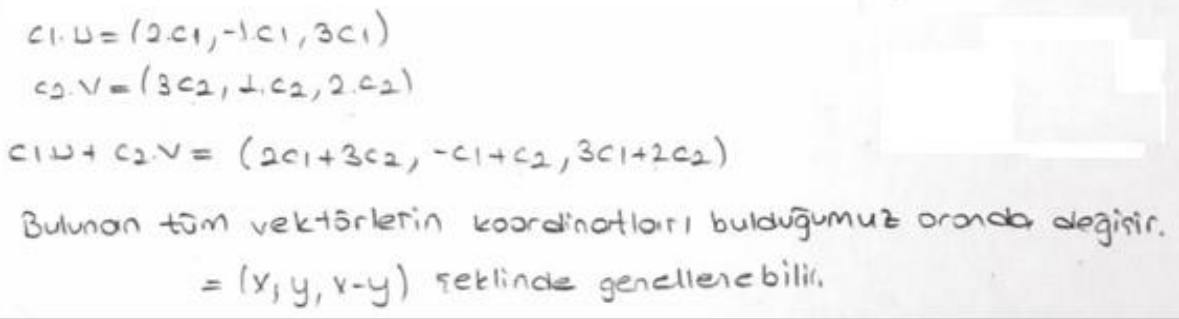

Figure 10. Students' answer to question 4

The answers given by the students to the question are mostly as shown in Figure 10. In fact, the problem had two purposes. The first was to carry the students' thinking level about the concepts of vector sum and multiplication with scalar to an analytical-arithmetic way of thinking by using their previous concrete experiences. The second was to reach the idea that the sum and the multiplication with scalar of vectors in $\mathrm{R}^{2}$ and $\mathrm{R}^{3}$ are still in the same set before vector space concept. However, it was observed that the set of linear combinations of two vectors was obtained with the solution of the problem and the desired result could not be achieved. Because the students did not provide explanations or justifications for their solutions. They used only arithmetic operations in their solutions. For this reason, this question was removed from the worksheet and an example from $\mathrm{R}^{3}$ was given instead in order to increase the students' concrete experience. This question is included in the figure below.

\section{Create the vector $u=(3,1,2)$ on the $3 D$ graphic screen of the geogebra.}

Create a slider for the vector u using the software's slider command. How does the vector $v$ change when you move the slider? Describe your result by discussing it with your groupmate.

5 Compute algebraically the vectors for the 2 and -3 values of the slide. Explain how you got the resulting vectors.

Figure 11. The revision made to question 4

After the changes made as seen in Figure 11, the worksheet was prepared for the 3rd cycle with arrangements formalistically.

\section{Vector Space and Subspace}

The most important problem encountered in the first and second cycles in the implementation of the activities prepared for the teaching of vector space and subspace concepts is that the duration designed for the activities was exceeded. The vector space activity contains problems, in which the conditions of being vector spaces are controlled, based on the geometric representations of four different sets. The geometrical construction of each cluster was left to the students, and students either spend a lot of time to form these structures or were unable to draw them. In this case, it naturally caused the prolongation of the time.

It was decided that it would be more appropriate to prepare ready-made GeoGebra templates in order to overcome the difficulties that students have in creating geometric structures in the vector space activity. Thus, it was aimed to create the geometric structures related to the given sets in a fast and accurate way and accordingly strengthen the intuitive understanding of students. Because it has been observed that students have difficulties in creating geometric structures and lost time. In addition, these difficulties were hampered the aim of creating intuitive understandings in teaching the concept. It was observed that some students who could not make the drawings quit the activities and waited for the lecturer. For this reason, the Geogebra templates named as Problem1, Problem2, Problem3 and Problem4 were prepared for each problem situation, and it was aimed for students to quickly check each of the vector space conditions. In addition, it was aimed to prevent students from making assumptions on false concrete models and to improve students' modes of thinking. The following figure is the GeoGebra template for Problem1. 


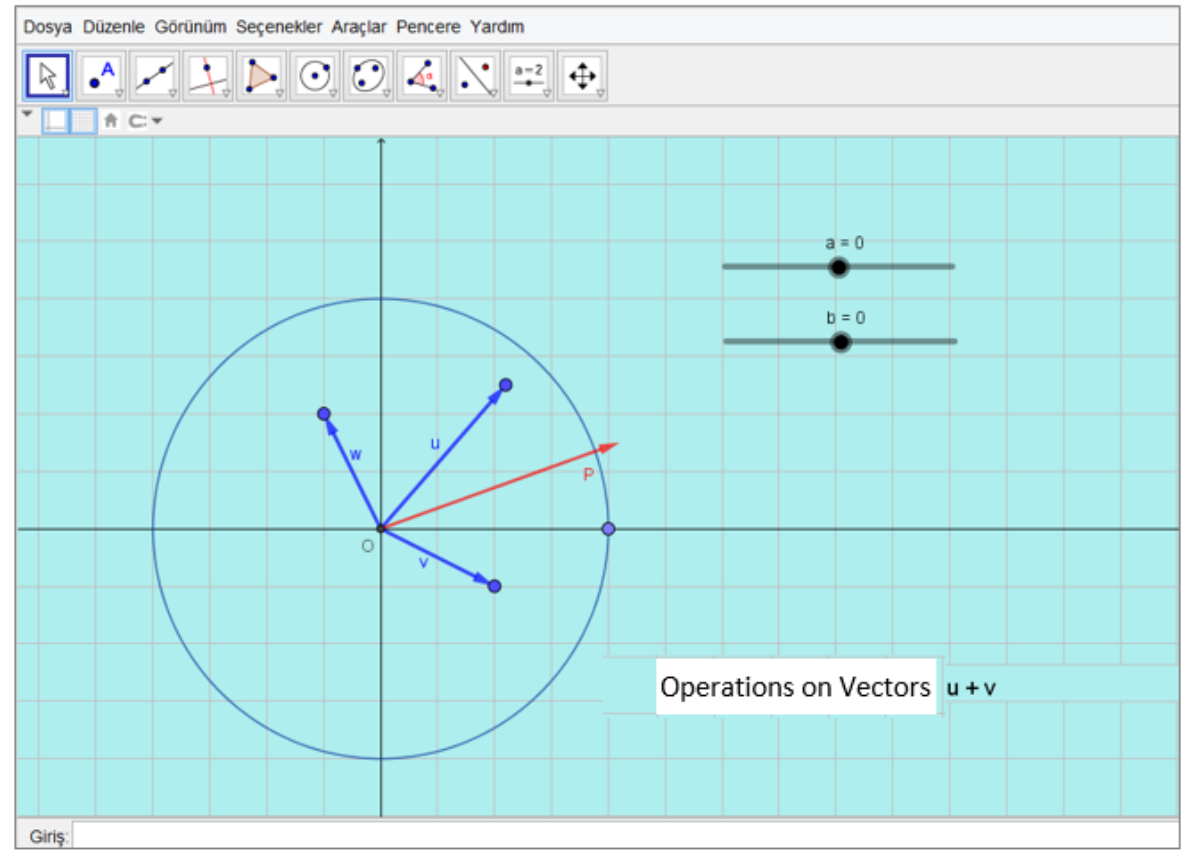

Figure 12. GeoGebra template designed for subspace concept

As seen in Figure 12, the geometric structure (circle in this question), vectors and sliders in the problem were presented to the students as a ready-made template. It was aimed that the students to control by writing the conditions of being vector spaces in the "Operations on Vectors" section of the template and to reach the concrete content correctly and quickly by using the dynamic structure of the software. Templates were created by using the same technique for other problem situations. In addition, with the command "Operations on Vectors", it was aimed that students to establish the connection between geometric and algebraic representations of concepts.

Despite the revisions made in the GeoGebra template, no changes were made regarding the structure of the questions in the worksheets but revisions were made in the presentation of the questions and in the formal structure of the worksheets to arouse curiosity and make the activity more fluent. The definitions and geometric representations of each set were presented in the worksheet as a whole, and for each question, the students were asked to investigate whether the sets meet the conditions of being vector spaces according to the standard operations defined in $\mathrm{R}^{2} . \mathrm{n}$ addition, unlike the previous one, the algebraic representation of the sets for each problem is given. Worksheet 5 is given below after the revisions made.

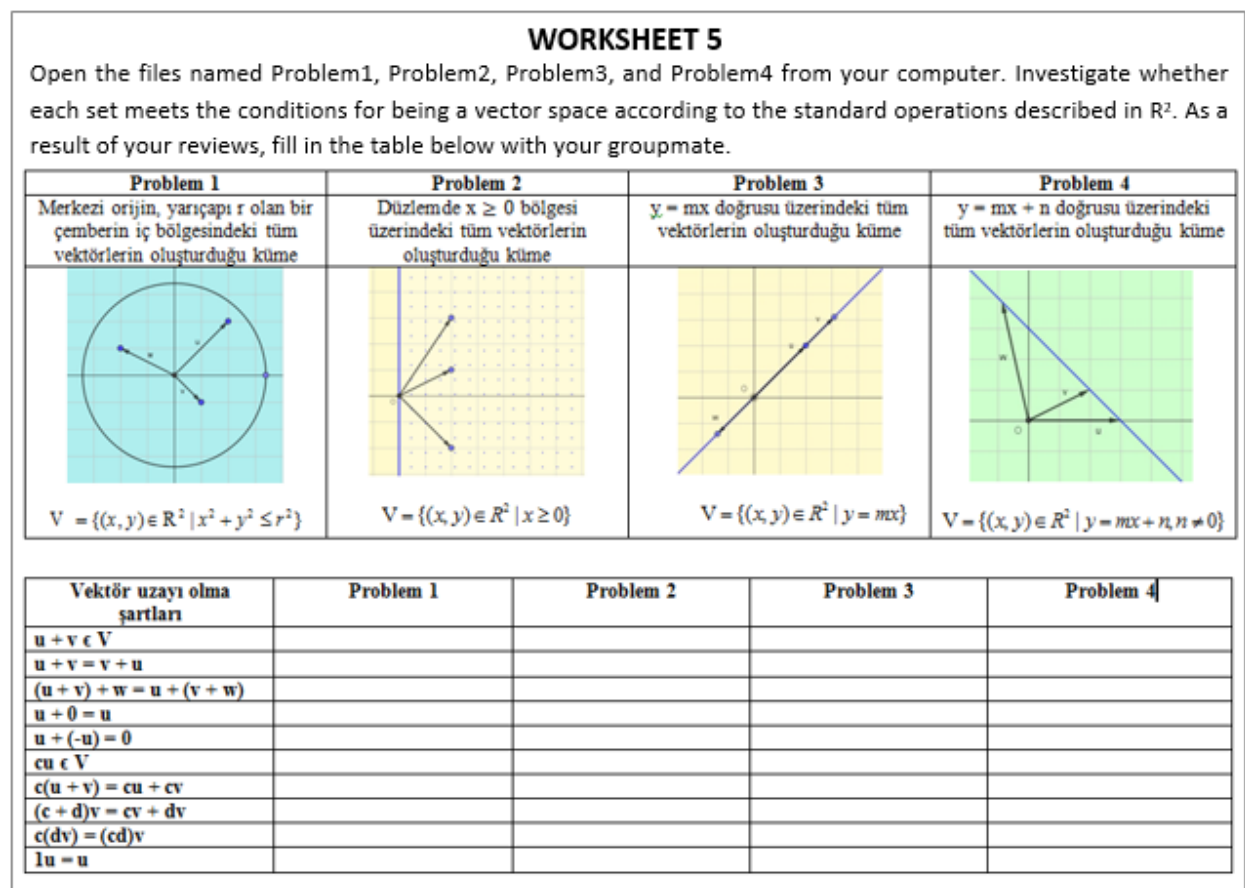

Figure 13. Worksheet 5 after the revisions made. 
As seen in Figure 13, the problems were presented in this way and it was aimed to be simpler and more understandable. In addition, additional paper were given to students to encourage them to use different languages, and they were asked to develop different solutions, if any, apart from their geometric solutions. Because students generally solved the given problem situations by using geometric inferences, but it was observed that they did not develop algebraic solutions. Below, the researcher's field note on this topic and sample student answer are given respectively.

"When looking at the answers given by the students to the questions in Activity 1, it was examined whether the conditions of being vector spaces of the given sets meet geometrically, just like in the first group. However, it was observed that many students did not respond algebraically on the worksheets."

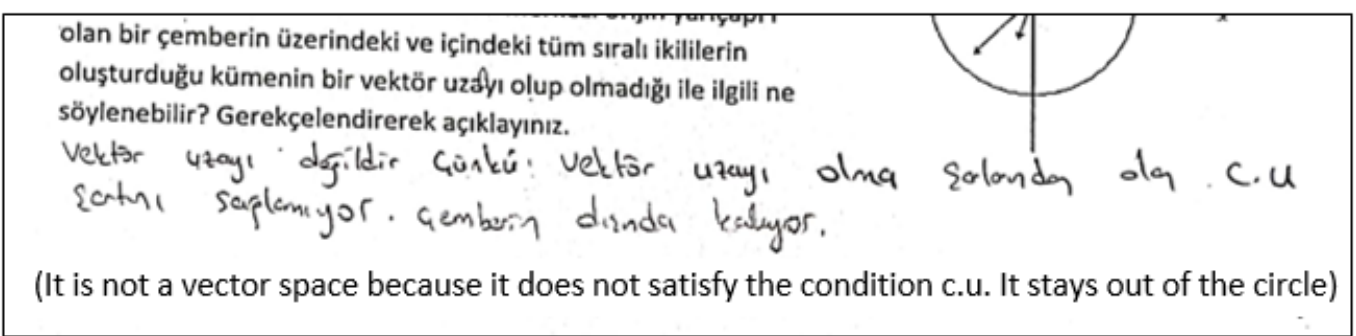

Figure 14. Sample student response

As seen in Figure 14, students used descriptions of geometric solutions instead of algebraic operations while answering the questions.

\section{Linear Combination and Span}

After the implementation of the activities prepared for the teaching of linear combination and span concepts, it was decided to make some changes in the GeoGebra template and activities. Although the activities were implemented more fluently than the first cycle, it was observed that the problem of time continued in this activity. To eliminate this problem, some questions were combined and asked again in order to simplify the activity a little more and make it more understandable.

During the implementation, it took the students' time to create geometric structures in some questions and therefore the time determined for the activity was extended. In this respect, problem encountered in the first cycle continued, so GeoGebra template was changed. First, the template was changed formalistically and the vectors and sliders were presented under separate headings. It was observed that the students made simple mistakes (multiplying the vector with the wrong scalar, incorrect use of the sliders, etc.) in the parts where they had to operate with more than one vector, and therefore they lost time. In order to avoid these simple mistakes and to create geometric structures in a much shorter time, it was decided to add an input field under the name of "Vector Operations" to the GeoGebra template. The input field is a feature that reflects the geometric equivalent of the algebraic representations of a concept to the screen. GeoGebra template is given below after the revisions made.

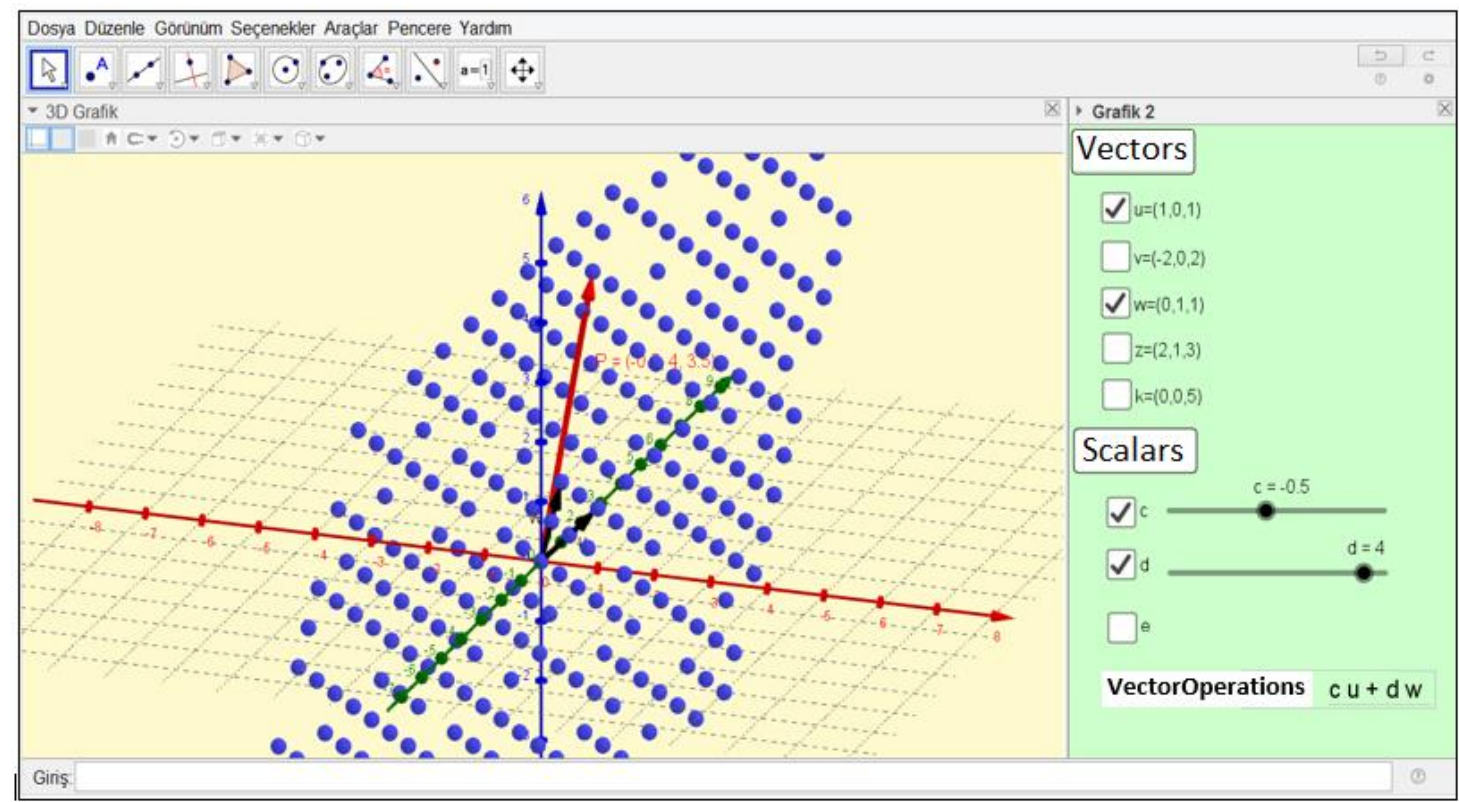

Figure 15. GeoGebra template after the revisions made 
When the expression "cu $+d w "$ is written in the vector operations field at the bottom right of Figure 15 , a red vector appears on the screen. Thus, it was aimed to overcome the difficulties experienced by the students in forming geometric shapes and making inferences about the concepts. In addition, it is aimed to shorten the implementation period of the activity. After these changes, the activity was named as worksheet 8 .

\title{
Linear Dependence/Independence
}

In the activities prepared for the teaching of the concepts of linear dependence and independence, changes were made formalistically in general and some simplifications were made together with it. The activity prepared in the first cycle was very verbal and some changes were made in this direction. In the second cycle, it was observed that it took time to examine each of the vector sets given in the questions separately. The researcher summarized this situation in the field note as follows.

\begin{abstract}
"After the implementation in the first group, some changes were made in the activity and the implementation in the second group was started. In our first implementation, there was no a ready-made Geogebra template for the activity. Instead, the students were asked to take a geometric approach to the question by using the Geogebra software and drawing the vectors they had determined themselves. However, as the students did not prefer to use the program too much, they had difficulty in bringing a geometric approach, and mostly focused on worksheets. In this case, we observed that some students were bored with the lesson."
\end{abstract}

In this respect, the vector sets which given to the students to examine their linear independence were reviewed, repetitive examples were determined and it was aimed to provide the most effective learning by using the least number of vectors. For instance, in the second question, five vectors in R3 and all binary vector sets that will be created with these five vectors were given to students. After the examination, the number of vector sets was reduced to 6 by removing the repeating samples. questions in worksheet are given below after the revisions made.

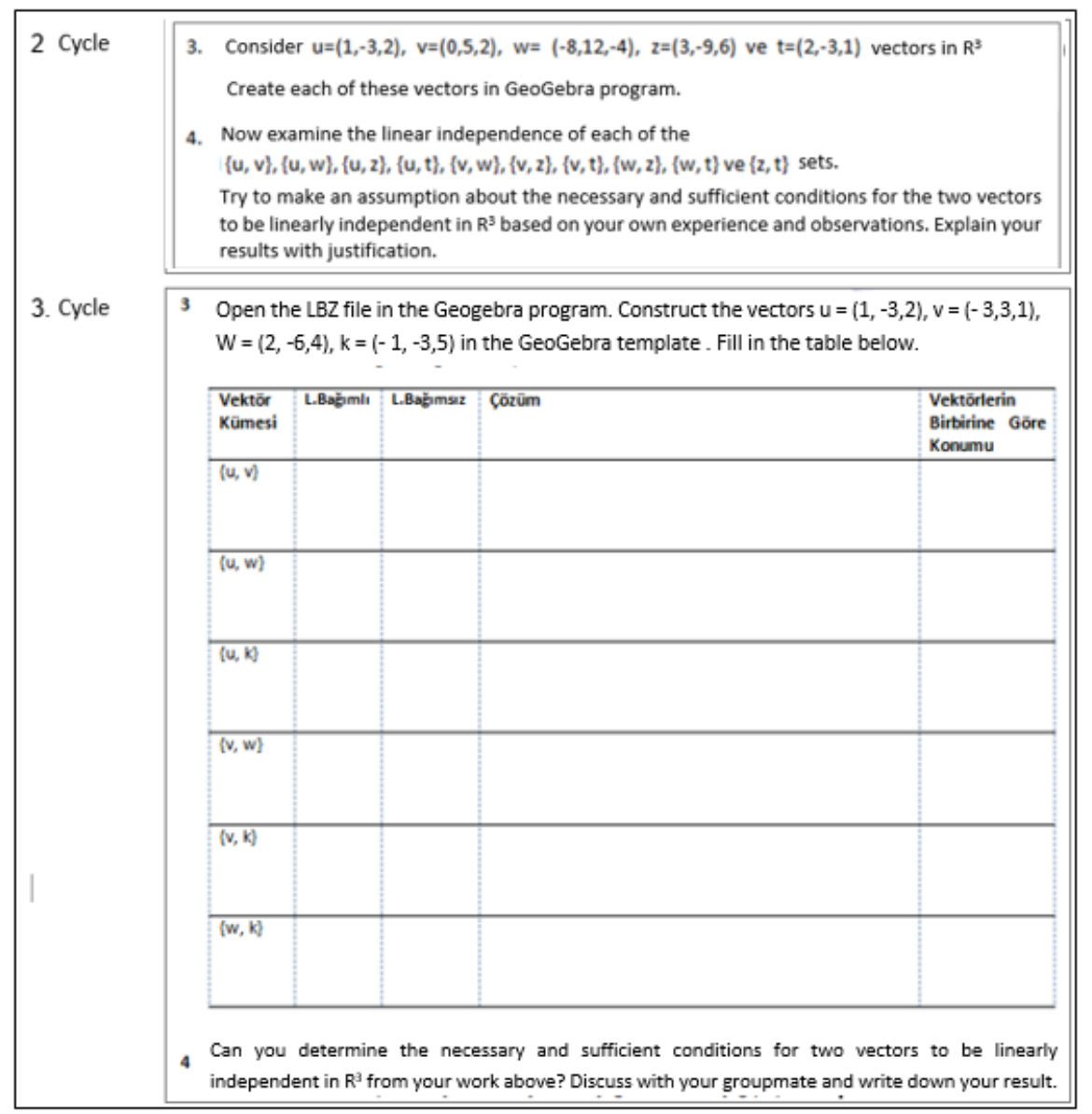

Figure 16. The revisions made to questions 3 and 4

Similar to Figure 16, fifth and sixth questions in the worksheet were changed and the number of vector sets was reduced to 4 from 6 by removing repetitive cases. In addition, in this part of the activity, it was observed that the students took notes in a confused way on worksheet and therefore lost time in making assumptions. Below, the researcher's field note on this topic and sample student answer are given respectively.

"While I was walking around the classroom and examining the students' answers to their worksheets, I observed that the procedures were done in a very scattered way and in a hurry. They also seemed to find it difficult to relate 
the results they found. So, It was deemed appropriate to change the worksheet formalistically in order for them to perform their operations more easily and to see the relationships easily."

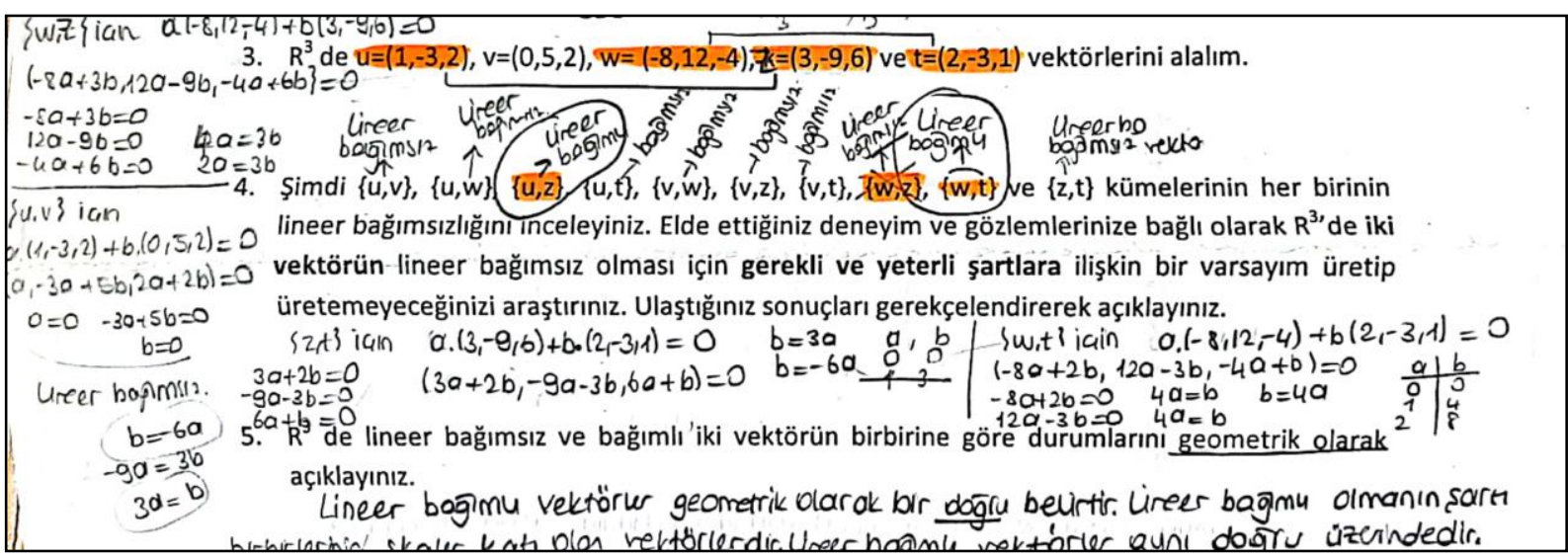

Figure 17. Sample student response

Looking at Figure 17, it is seen that the solutions made by the student are located in the worksheet in a confused way. Based on the field notes, the questions were presented in a table format in which the students would make and interpret their solutions more regularly. A similar situation was not encountered in activity 2 and activity 3 . The researcher only redrew the figures in activity 3 more professionally and added them to the activity. Finally, the activity is named as worksheet 10 .

\section{Base and Dimension}

After the implementation of the second cycle, some arrangements were made in terms of both form and content in the activities prepared for the concept of base and dimension. No change was made in Activity 2 , which included true/false questions. All arrangements were made in activity 1. Below are the researcher's field notes.

"During the implementation, there were no situations students had difficulty. After the previous cycle, some vector sets from $\mathrm{R}^{3}$ was added to Activity 2 in order to contain all possible situations and it was observed that the students did not have any difficulties. For the same reasons, it was thought that it would be appropriate to add vector sets from $\mathrm{R}^{3}$ to Activity 1."

Based on the field notes, it was decided to add vector sets from $\mathrm{R}^{3}$ vector space to activity 1 so that the students' learning about the concept of base and dimension is not limited only to the $\mathrm{R}^{2}$ vector space and to make a right generalization. all possible cases were selected while determining the sets in order to examine the bases of the vector space R3. Finally, Activity 1 and Activity 2 were combined and name as Worksheet 11.

\subsection{Study Story of Third Cycle}

The third and last cycle of the study was conducted with 11 students enrolled in a state university's secondary school mathematics teaching program and taking linear algebra in the spring semester of the 2017-2018 academic year. The application covers the basic concepts of vector space, subspace, linear combination, span, linear dependence, linear independence, base and dimension as in the other cycles. Before starting the applications for the first cycle, GeoGebra software was introduced to the students during a two-hour lesson. Most of the lessons were conducted in a laboratory environment. The activities were implemented in groups of two with students in the laboratory lessons. During the course, the students were asked to fill in the worksheets interactively with the GeoGebra software. During the application, two homework were given to students in each lesson as in the other cycles. Last cycle of the research was conducted by a mathematics educator who was an expert in her field, and the researcher took the role of observer by taking video recordings and observation notes.

The principles regarding the designed learning environment were gathered under five main titles before the third cycle: Use of Technology, Modes of Description, Task, Worksheets and Group Work. As a result of the findings obtained in the third cycle of the research, the Role of the lecturer was added to the design principles as a sixth title. Thus, it was decided to gather the principles related to the designed learning environment under six titles. The principles regarding the role of the lecturer are determined to be active, collaborative, aware of the structure, equal to all and in interaction. In accordance with the nature of design-based research, researchers have an active and collaborative attitude in the process. However, it has been revealed in the field notes and video recordings that the role of the lecturer is not always limited to these. The fact that the lecturer gave the right to speak to all students emerged as a situation that attracted the attention of the students and the researcher. The researcher summarized this situation in the field note as follows. 
"The satisfaction of the students especially with the attitude of the lecturer was remarkable. It $i$ also observed that some students expressed their satisfaction with this situation directly to their teachers. In a dialogue between one of the students and the lecturer, he said that everyone was treated equally because the teacher was constantly walking around.

After the third cycle, in addition to adding the role of the lecturer as a title to the principles regarding the learning environment, some principles were included under other titles based on the findings. Getting attention, practical and compatible and preparing ground for formal definitions and proofs were added to title of use of technology. Discussion and giving feedback were added to title of tasks. Practical was added to title of worksheets. In particular, discussions and feedback which based on the questions in the task were effective to understand the students' modes of thinking and the to make help them to development of their modes of thinking. Below is the field note of the lecturer regarding this situation.

“.... For instance, a student asked a question that we could solve the problem in $\mathrm{R}^{2}$ or $\mathrm{R}^{3}$. Several students in the class stated that the question should be answered in a general form. Even, the misunderstanding of students emerged regarding the relationship between $R^{2}, R^{3}$ and $R^{n}$. This gave me the opportunity to talk about it. Since this process is recorded, the dialogues in the classroom can be analyzed carefully. The discussion environment about tasks has once again demonstrated how effective specific assignment and follow-up is."

When the field notes of the lecturer were examined, it was revealed that the discussion environment in the classroom was effective in revealing the misunderstandings of the students and correcting these mistakes. Apart from that, no problem was encountered in the application of GeoGebra templates and worksheets used in the learning environment and it was observed that they were used by students in a practical way. In particular, the revisions made in the first two cycles were effective in the formation of this practicality. In addition to this, in line with the determined principles, the learning environment was successfully implemented in the third cycle. Below is the researcher's field note on this subject.

"I can say that the application carried out in the course was very efficient and reached the desired goal for the students. No problem was encountered in the presentation or understanding of the questions in the activities. Thus, the application was carried out efficiently in a lesson environment where I, the lecturer and the students were active and the students' motivation did not decrease. In fact, two male students, who did not attend the lesson as often as their other friends, were interested in the activities from the beginning to the end of the lesson, they asked questions and mostly made correct inferences. I think this was clear evidence of how the designed environment attracted and motivated students."

When the field notes of the lecturer were examined, it was seen that he had similar views with the researcher. Below are the field notes of the lecturer regarding the learning environment.

\begin{abstract}
"In general, the interest of the students in the class was good. They got rid of their inexperience in teaching the lesson with worksheets. In the lesson, I noticed that they could easily summon information from previous topics when needed. Moreover, the students were trying to visualize their experiences in the classroom while changing the wrong answers they gave in class discussions. I think that these applications were generally efficient, and then they facilitated the processes of understanding the structure and proof of the theorems we wrote. In addition, even students who seem very indifferent to the lesson were involved in the in-class practices. They did not exclude themselves like in other lessons."
\end{abstract}

In the successful implementation of the learning environment, it was effective for the lecturer to have a command of the current structure in the learning environment and to manage the process well. The lecturer and the researcher came together before and after the lesson and held small meetings for a right implementation of the learning environment. It is thought that group work is also effective in the success of the learning environment. Lessons taught in the laboratory environment were conducted in group work. Under the title of group work, the principles are determined as student-centered, discussion and motivation.

Considering the dialogues with the students and the students' performances in the lesson, it was found that group work increased students' responsibility and self-confidence. In addition, the students found the teaching of the lessons in the form of group work enjoyable and stated that they preferred laboratory lessons to normal classroom lessons. Based on the findings, it is thought that doing group work has an effect on this choice. Below is the researcher's field note on this subject.

It was observed that the lessons and activities were very efficient and understandable. Particularly, students' expressing their own ideas, asking questions and searching for solutions by making inferences from the activities made them an active part of the course. When the course was taught entirely in the laboratory, it was observed that the students were tired only towards the end of the lesson. Some students stated that they got very tired in the normal classroom environment and that the laboratory lessons were more enjoyable and less tiring. This situation once again revealed how formalism pose a obstacle for students.

Parallel to this, a similar situation was encountered when video recordings were examined. In a dialogue between the lecturer and the students in a lesson in a classroom environment, the students stated that they were bored from time to time in the classroom and wanted to do their lessons in the laboratory. When the lesson 
lecturer asked why they wanted to do lesson in the laboratory, they showed the time flies and group work as a reason.

\section{Discussion}

In this study, a theoretical framework was organized by determining the difficulties and suggestions in the literature for linear algebra teaching and a learning environment was designed by determining some principles in line with this framework. The designed learning environment was implemented in three cycle application design and evaluation process within the scope of design based research. Before the last cycle of the research, adjustments and changes were made during the first two cycles of the learning environment designed using field notes and video recordings. As a result of the revisions made after the first two cycles, design principles were determined before the third cycle and the design was made ready for implementation before the last cycle.

After the first two cycles, the principles related to the designed learning environment were formed under five titles: Use of technology, modes of description, tasks, worksheets and group work. After the third cycle of the research, as a result of the analysis of the students' views, a sixth title under the name of the lecturer's role was added to the design principles. Thus, the design principles of the learning environment for teaching vector spaces are grouped under six titles. The principles regarding the lecturer's role are determined as being active, collaborative, and aware of the structure, equal to all and in interaction. In fact, we can state that the researcher is active and cooperating with the students during the application (Reeves, 2000) as one of the characteristics of TTAs, the learning environment is an invisible principle. However, as a result of the analysis of the students' views, it was revealed that the lecturer's role is not limited to these features. In the present study, the first and second cycles were carried out by the researcher, and the third cycle by another lecturer. For this reason, it is important for the lecturer (course teacher) to be aware of the process and design principles and to conduct lectures in accordance with these principles. Because in all of the activities, different languages and representations have been systematically used for the development of students' thinking modes. Being aware of this structure, the lecturer should pay attention to the use of languages and transitions between languages, both in their interaction with students throughout the process and in their in class practices. Otherwise, difficulties arising from not understanding the transitions between languages stated in the literature (Hillel, 2000) will be encountered. However, the students stated that it is a situation that motivates them to behave equally to everyone and to give everyone the right to speak. It is possible to say that these behaviors exhibited by the lecturer and his communication with students (Pecuch-Herrero, 2000) are very important and increase students 'success in terms of students' ability to express their thoughts clearly. However, the fact that the lecturer treats everyone equally and gives everyone the right to speak has been an important factor in motivating the students. It is possible to say that these behaviors exhibited by the lecturer and his communication with students (Pecuch-Herrero, 2000) are very important and increase students 'success in terms of students' ability to express their thoughts clearly.

The principles determined regarding the use of technology are mostly to determine the role of GeoGebra software in the learning environment. By including technology in the learning environment, it was aimed not only to meet the recommendations in the literature, but also to apply the pedagogical principles suggested by Harel (2000) and to avoid the formalism difficulty mentioned by Dorier (1995). As a result of the analysis of the findings, some features that the templates prepared with GeoGebra software should have were determined, apart from the basic purposes stated. The features of the templates were determined as remarkable, practical, compatible with the content and preparing students for formal definitions and proofs. Although the remarkable and practical usage are the considerations when preparing the GeoGebra templates, it is not included in the principles of technology use. In particular, practicality is a feature that all students and lecturer agree on and has played an important role in the effective use of time. However, even though the students were taught before the implementation of the software, some activities (subspace, span) caused difficulties arising from using the software and causing the time to increase. Therefore, the preparation of a template that will provide practical use to the students has contributed to the principles of using time effectively and handling a large number of cases. However, the compatibility of the designed GeoGebra templates with the content and worksheets was also revealed in the interviews. It is also stated in the literature that the use of simple CAS and DGS (DonevskaTodorova, 2018) does not make linear algebra teaching easy. Considering that technology increases student achievement when applied together with teaching strategies (Donevska-Todorova, 2018; Pecuch-Herrero, 2000), it can be said that the designed templates should be implemented in a systematic manner and compatible with other activities used in the lessons. The integration of technology into linear algebra course should not be thought of as only including visual representations of concepts or supporting content. Worksheets and tasks should also be organized by taking GeoGebra templates into consideration and activities should support each other. In addition, the lecturer stated that the concrete experiences provided by the software helped the students to understand formal definitions and proofs. This opinion stated by the lecturer is compatible with the concreteness and generalizability principles of Harel (2000), and it was decided that this view should be one of the principles regarding the use of technology. 
Given that the worksheets are implemented with GeoGebra templates, practical use with the software also emerges as a feature of the worksheets. Worksheets used in the study are activities that have many revisions both in content and form since the first cycle. While preparing the worksheets, many formal revisions have been made so that students can easily make their solutions, make assumptions on their solutions and establish relationships. Because the findings obtained from the first and second cycles revealed that the students made solutions in a scattered way and sometimes had difficulty in collecting the results they obtained. Although the practical preparation of the worksheets is not expressed as a principle while creating the design principles for the learning environment, attention has been paid to the practicality of the worksheets. As a result, the principles determined for the worksheets after the first and second cycles were determined as curiosity, clear and understandable, generalizing, including different languages, compatible with software and discovering. As a result of the opinions and observations made throughout the process, it was decided that practical use should be one of the points to be considered in the preparation of the worksheets. It was revealed that the principles determined from the opinions of the lecturer and students were successfully met in the worksheets. However, observations, worksheets and homework revealed that students realized and adopted the purpose of the learning environment. This situation is thought to contribute to meeting Harel's (2000) requirement principle.

Principles under the title of task after the first two cycles, it is presented as problem solving, making generalizations, using different languages and representations. In the light of the findings obtained from the observations, it has been concluded that task is effective in students' learning more deeply and exhibiting their thinking modes. Opinions about task were determined as reinforcing, repeating the lesson, preparing for the exam, taking the exam stress and working regularly. Based on the students' views, it is possible to say that task contributes positively to their learning. However, seeing task as a compulsory task has emerged as a striking situation in students' views. It is thought that this situation is caused by regularly giving feedback to task and students feeling responsible for the lesson. In addition, from the interviews with the lecturer, it was concluded that the task was effective in creating a discussion environment in the classroom. For this reason, the principles determined under the title of task; it was decided to add the principles of learning, discussion and giving feedback. However, another important point to note here is that task makes students ready for the exam and relieves them from exam stress and score anxiety. In this case, it is strongly thought that it is effective in students' display of analytical-structural thinking in their answers to the questions. Task is also an important factor in creating a discussion environment in the classroom. Class discussions were held during the lessons by sharing their thoughts with each other over the task questions. This situation enabled both the students to express their opinions clearly and the misunderstandings of the lecturer and to correct these mistakes. Therefore, it was thought that the task should be discussed in the classroom and should be composed of pondered questions in order to reveal the students' ideas and the development of their thinking modes. Of course, the role of the lecturer is also effective in creating a discussion environment. It is thought that doing task has an effect on the feedback given to the task in terms of feeling a responsibility and obligation for them. The lecturer stated that the feedback given to the task motivated the students. In this respect, it is thought that task has an important place in meeting the requirements and generalizability principles of Harel (2000). Because task can also be considered as a problem-solving activity and allows students to learn in the most general form by including different languages and notations. In this respect, giving feedback has been determined as a principle for task so that such an activity is seen as a necessity by students. It kept students' motivation towards the lesson high and made the lesson more enjoyable. The students' preference of lab lessons, which are conducted in the form of group work, over classroom lessons can be interpreted as an indicator of how much formalism exhausts students. In this context, it is possible to say that group studies motivate students against the formalism difficulty (Dorier, 1995) stated in the literature. As a result, in addition to the suggestions in the literature against the difficulty of formalism (Harel, 2000; Tabaghi, 2012), it can be added that lessons are sometimes held in group work.

\section{Conclusion and Suggestions}

In this study, considering the theoretical framework on Linear Algebra teaching, it is aimed to determine the design principles of a technology-supported learning environment for teaching vector spaces. The design principles, which were gathered under five headings after the first two cycles, were gathered under six titles with the addition of the title of the role of the lecturer as a result of the analysis of the findings obtained after the third cycle, and the principles were finalized by adding some titles. As a result of the research, design principles, use of technology, use of representation languages, assignments, worksheets, group work and the role of the lecturer were determined.

Drawing attention to the use of technology, preparing the ground for harmonious, practical and formal definitions and proofs; learning, discussing and giving feedback to assignment; The principles of avoiding the difficulty of formalism have been added to group work. While determining the design principles, first the principles were determined in line with the theoretical framework of the research, and then a learning environment was designed by considering the student difficulties and suggestions for linear algebra teaching in the literature. While preparing GeoGebra templates, worksheets and assignments, which are the components of 
the learning environment, geometric, algebraic and abstract representations of the concepts were included, and activities were prepared to meet the principles of concreteness, necessity and generalizability in each component. Thus, the design principles of a learning environment designed for teaching vector spaces were formed.

Use of technology;

- Making connections between algebraic and graphical representations

- Concretization and visualization

- Avoiding the formalism obstacle

- Using time effectively

- Including a large number of questions

- Getting attention

- Practical and compatible

- Preparing ground for formal definitions and proofs

While technology is included in the lessons, it is important that the materials prepared are designed in a way to establish a relationship between the algebraic and graphical representations of the students. Including concrete representations of concepts in these materials allows students to avoid the difficulty of formalism, as well as provide students with a basis for formal definitions and proofs through intuitive understandings. Apart from this, the technology materials should be designed to be attention-grabing, practical and compatible with other materials used in the course. In addition, in order to enrich students' understanding, it is important to include a large number of questions to set an example for all possible situations related to concepts and to include technology in a way that will use time effectively.

Use of modes of description;

- Assignments

- Worksheets

- GeoGebra templates

- In-class presentations

While designing assignments, worksheets, GeoGebra templates and making in-class presentations, it is extremely necessary to pay attention to the use of representation languages and to include different languages. It is one of the basic principles of the learning environment that the transitions between languages are understandable by students and that students are encouraged to use different languages. It is also important for the development of students' modes of thinking.

Tasks;

- Problem solving

- Generalizing

- Including different languages and representations

- Learning

- Discussion

- Giving feedback

While designing the assignments, in accordance with the principle of using representation languages, different languages related to the concepts should be included in the questions. Assignments should also be seen as a problem solving activity and should consist of thought-provoking questions that will lead students to generalize and discuss. However, giving feedback to assignments has emerged as an important factor for students to learn and keep their motivation high.

Worksheets;

- arouse curiosity

- Being clear and understandable

- Practical

- Don't make generalizations

- Including different languages

- Easy going

- Discovering

Just like assignments, different languages related to the concepts should be included when designing worksheets. It is very important that the worksheets have a structure that starts with geometric applications, supports the results obtained with these applications with algebraic approaches and ultimately leads students to generalize, and allows students to learn by discovering. Apart from this, the worksheets are designed to be intriguing in terms of both content and form, having clear and simple instructions, useful and compatible with other materials used in the course. 
Group work;

- Student centered

- Discussion

- Motivation

- Avoiding the obstacle of formalism

Conducting the activities as group work is important in terms of student responsibility and active participation, as well as meeting the student-centered teaching suggestions in the literature. Group work was seen as an effective factor in preventing formalism from tiring students, providing the opportunity to discuss with each other and having higher motivation towards the lesson.

The role of the lecturer;

- Active

- Collaborative

- In interaction

- Equal to all

- Aware of the structure

It is extremely important for the lecturer to be active, cooperative and interactive in terms of ensuring active participation of students in the lesson, revealing the wrong or missing information of the students and the development of their thinking. The lecturer has responsibilities in terms of conducting worksheets and geogebra templates in harmony in the learning environment, giving feedback to the assignment and creating a discussion environment in the classroom. In this regard, the study tells us that the lecturer should be aware of the process followed and the structure used in the learning environment. Apart from this, giving the students the right to speak and express their thoughts, giving students the opportunity to express themselves, using different languages and determining their thinking modes has emerged as a very important result.

While revealing the design principles of the research, the importance of the role of the lecturer in the learning environment was emphasized. The performance of the lecturer in the learning environment attracted the attention of the students and motivated them. Here, one of the points to be considered for linear algebra lesson teachers is that the designed learning environment increases the responsibilities of the lecturer. Of course, teachers have responsibilities in the normal classroom setting, but a learning environment prepared in line with many different suggestions and design principles requires a different perspective and additional responsibilities along with the learning strategies adopted. In this respect, a researcher who will take part in a similar learning environment or a lecturer who adopts such an approach should pay attention to the following points:

1. Being responsible for synchronization between events

2. To create a discussion environment

3. To interact with students and give everyone a voice

4. Paying attention to the transitions between languages

Technology's place in the classroom in today's education world is undeniable. Not only linear algebra lessons, but also technological materials in many different branches from primary education to university take their place in classrooms. However, it should not be forgotten that assignment from past to present has an important place in teaching concepts. As a matter of fact, in this study, students were given assignment regularly every week. However, just as with the use of technology, assignment that is not supported by a specific strategy and given feedback is considered as a difficult possibility to contribute to students' understanding. Considering that the sloppy use of representational languages in classroom activities and textbooks is a challenge for students, their assignment should be prepared in a way that includes different representation languages so that students can differentiate. From this point of view, it is suggested that the concept-oriented assignment that includes geometric, algebraic and abstract representations of the concepts, regularly given feedback by the lecturer, should be used in teaching vector spaces concepts. It is also recommended to carry out similar studies in terms of designing new materials and learning environments in linear algebra teaching, taking into account the changes in technology in the future. 


\section{Vektör Uzaylarının Öğretimine Yönelik Bir Öğrenme Ortamının Tasarım İlkelerinin Oluşturulması}

\section{Giriş}

Lineer cebir, matematiğin; vektörler, vektör uzayları, lineer dönüşümler, lineer denklem sistemleri ve matrisleri inceleyen önemli çalı̧̧ma alanlarından biridir. Özellikle fen bilimlerinde yaygın bir kullanım alanına sahip olan lineer cebirin; anatomi, mühendislik, bilişim sistemleri, genetik, fizik ve istatistik gibi birçok alanda da uygulamaları bulunmaktadır. Öğrencilere matematiksel soyutlama yapma firsatı sunan bir ders olması, lineer cebiri önemli kılan nedenler arasında gösterilmektedir (Harel, 1989a; Kolman ve Hill, 2008). Harel (1989a), lineer cebirdeki konuların kendi içinde olduğu kadar yaşamın her alanında bulunması gereken nitelikte olduğundan hareketle pek çok müfredat için gerekli bir ders olduğunu ifade etmiştir.

Lineer cebir dersi genel olarak Matris Cebiri ve Vektör Uzayları Teorisi olmak üzere iki temel bölüme ayrılabilir. Matris Cebiri; matrisler, matrislerde işlemler ve özelliklerini, determinantlar ve lineer denklem sistemleri ile çözüm yöntemlerini içermektedir. Vektör Uzayları Teorisi; vektör uzayları, alt uzaylar, lineer birleşim, germe, lineer bağımlılık, lineer bağımsızlık, taban ve boyut gibi kavramları içermektedir. Çok daha soyut bir yapıya sahip olması sebebiyle vektör uzayları teorisi, öğrencilerin lineer cebir dersinde en çok güçlük yaşadığı bölümdür (Dorier, 1995). Dorier’e (1995) göre lineer cebir öğrenme ile ilgili olarak öğrencilerin sahip olduğu zorluklar, onun soyut ve formal doğasının bir sonucudur.

Lineer cebir öğretimi üzerine yapılan araştırmalar incelendiğinde ağıllıklı olarak vektör uzayları ve lineer dönüşümler üzerinde durulduğu görülmektedir (Britton ve Henderson, 2009; Doğan-Dunlap, 2010; DonevskaTodorova, 2018; Dorier 1998; Dorier, Robert, Robinet ve Rogalski, 2000; Harel, 1987; Klasa, 2009; Sierpinska, Dreyfus ve Hillel, 1999; Stewart ve Thomas, 2010). Konuyla ilgili araştırmaların daha ağırlıklı olarak vektör uzayları teorisi üzerinde olmasının sebebi, vektör uzayları kavramlarının doğası gereği soyut olmasından dolayı öğrenmede ve de öğretmede güçlükler yaşanmasından kaynaklanmaktadır. Robert ve Robinet (1989), öğrencilerin derse yönelik temel eleştirilerini formalizmin kullanımı, çok sayıda yeni tanımın yer alması ve daha önceden öğrendikleri bilgilerle yeni öğrendikleri bilgiler arasında ilişki kuramamak olarak belirlemişlerdir. Dorier ve arkadaşları (2000) bu durumu "Formalizm zorluğu" olarak isimlendirmiş ve birçok durumda formalizm engelinin öğrenci zorluklarının nedeni olduğunu belirtmişlerdir.

Lineer cebir dersi, birçok yeni kavram ve bu kavramların özelliklerini içermektedir. Bu derste öğrencilerden kavramlarla ilgili belli durumlarda değil $\left(\mathrm{R}^{2}, \mathrm{R}^{3}, 2 \times 2\right.$ tipinde matrisler, ...) en genel durumlarda ( vektör uzayları, lineer dönüşüm sınıfları, cebirsel yapılar, ...) düşünme ve çalışmaları beklenmektedir (Hillel, 2000). Ayrıca öğrencilerden, bu yapılar üzerinde dönüşümler tanımlama, farklı temsil dillerini de kullanmaları beklenebilmektedir. Hillel'e (2000) göre lineer cebir kavramları üç farklı tanımlama ve ilişkili olarak temsil diline sahiptir. Hillel (2000) lineer cebirde kullanılan dilleri geometrik dil, cebirsel dil ve soyut dil olarak üç başlıkta ele almıştır. Her bir dil içerisinde vektörler, vektörler üzerindeki işlemler ve dönüşümler özel tanımlara ve gösterimlere sahiptir. Örneğin bir vektör geometrik dilde bir ok olarak, cebirsel dilde sayılardan veya sembollerden oluşan satır veya sütün matrisi ve soyut dilde bir vektör uzayının elemanı olarak temsil edilmektedir. Sınıf içi öğretimde veya ders kitaplarında, kavramlar ve ilişkili süreçler tanımlanırken bu üç temsil dili bir arada kullanılır (Hillel, 2000). Sürekli olarak birinden diğerine geçiş yapılır. Bu tanımlama ve temsil dilleri arasındaki ayırımı yapamayan bir öğrenci için birinden diğerine geçişi anlamak ve takip etmek temel zorluk nedenleri arasında yer almaktadır.Bu temsil dilleri dışında lineer cebirde öğrencilerin farklı tanımlama ve temsil dilleri ile ilgili anlamalarının gelişimi için düşünme biçimlerine ihtiyaç olabilir.

Sierpinska (2000), lineer cebirde kullanılan üç düşünme biçimi tanımlamıştır. Bu düşünme biçimleri; Sentetik-Geometrik, Analitik-Aritmetik ve Analitik-Yapısal düşünme biçimleridir. Sierpinska (2000) bu üç temel düşünme biçiminin gelişimine ihtiyaç olduğunu ifade etmiştir. Sentetik-Geometrik düşünme biçiminde öğrenciler tanımlama yapmaksızın verilen matematiksel nesneleri betimlemeye çalışırken Analitik-Aritmetik ve Analitik-Yapısal düşünme biçimlerinde, öğrencilerin nesneleri tanımları ve özelliklerini kullanarak anlamaya çalşması söz konusudur (Sierpinska 2000). Bu düşünme biçimleri Hillel'in (2000) bahsettiği temsil dilleri ile açık bir şekilde ilişkilidir. Sentetik-Geometrik düşünme biçiminde kullanılan dil, $\mathrm{R}^{2}$ ve $\mathrm{R}^{3}$ 'ün geometrik dilidir. Analitik-Aritmetik düşünme biçiminde kullanılan dil $I^{\mathrm{n}}$ nin cebirsel dili iken, Analitik-Yapısal düşünme biçiminde kullanılan dil genel soyut teorinin soyut dilidir (Turğut, 2010). Ayrıca temsil dilleri ve Sierpinska (2000) tarafindan tanımlanan düşünme biçimleri tam olarak aynı şey değildir. $\mathrm{IR}^{\mathrm{n}}$ 'de çalışan bir öğrenci analitikaritmetik düşünme biçiminin yanı sıra sentetik-geometrik ve analitik-aritmetik düşünme biçimlerini de kullanması mümkündür. Analitik-Yapısal düşünme biçimi en üst düzey düşünme biçimidir ve bu düşünme biçiminin yapısına hâkim bir öğrenci diğer düşünme biçimlerinin özelliklerini de kullanabilir.

Harel (1989a), öğrencilerin lineer cebir kavramlarını anlama ve kullanmadaki temel güçlüklerinin nedenini, sağlam sezgisel bir temele oturtmaksızın soyut kavramların hızlı bir şekilde verilmesinden kaynaklandığını 
belirtmiştir. Harel (2000), lineer cebir öğretimine yönelik olarak üç temel pedagojik prensip önermiştir. Bunlar; Somutluk, Gereklilik ve Genellenebilirlik prensipleridir. Somutluk prensibi, öğrencilerin kendileri için somut olan bir içerikte belli bir kavramla ilgili anlamaları inşa edebileceği fikrine dayanmaktadır (Harel, 2000). Örneğin, analizde türev kavramından bahsedebilmek için öğrencinin fonksiyon kavramını bir matematiksel nesne olarak algılaması, $\mathrm{P}_{4}(\mathrm{R})$ üzerinde lineer birleşim kavramından bahsedebilmek için öğrencilerin bu kümenin elemanı olan her bir polinomu bir nesne-vektör olarak görmesi gerekmektedir. Gereklilik prensibi, öğrencilerin lineer cebir dersine aktif olarak katılmalarını ifade eder (Aydın, 2007) ve eğitimsel aktiviteler bu prensibin hayata geçirilmesinde önemlidir. Eğitimsel aktivitelerin öğrenciler tarafından gerçekçi ve kabul görülmüş problem durumlarını sunması gerekmektedir. Özel bir örnekle veya etkinliklerle öğrencilerin kavramlar arasındaki bağlantıları hissetmeleri ve görmelerini sağlamak kavramsal bir anlamanın oluşmasına zemin hazıryabilir ve böylece gereklilik prensibi uygulanmış olur. Genellenebilirlik prensibi ise öğrenme sürecinden çok öğretim materyallerinin seçimine ilişkin didaktik kararlarla ilişkilidir (Harel, 2000) Öğretim somut bir modelle ilişkilendirildiğinde somutluk prensibini destekleyici bir durum olur, bu model üzerinden yürütülen öğretimsel aktiviteler kavramın genellenebilirliğini sağlayabilir. Bu süreçte somutluk ilkesini karşılamak amacıyla yapılan etkinlikler önemli olabilir. Kullanılan somut modeller, soyut kavramların öğrenciler tarafından anlaşılmasına ve özümsenmesine olanak verecek şekilde düzenlenmelidir (Turğut, 2010). Model üzerinden yürütülen çalışmalar ile genel kavrama ulaşılabilmelidir. Modelin çok spesifik olduğu ve genel kavramla ortak noktasının çok sınırlı olduğu durumlarda genelleme gerçekleşmeyebilir.

1990’lı yıllarda 16 matematik eğitimcisinin oluşturduğu Lineer Cebir Öğretim Programı Çalışma Grubu (LACSG; Linear Algebra Curriculum Study Group) yaptığ 1 araştırmalar neticesinde lineer cebir öğretiminde yeni yaklaşımların benimsenmesini önermiştir. David Carlson, Charles Johnson, David Lay ve Duane Porter öncülüğünde kurulan grup, lineer cebir öğretiminin geliştirilmesine katkı sağlamayı ve bu konuya sağlam ve sürdürülebilir bir ilgi çekmeyi amaçlamıştır. LACSG araştırma grubunun lineer cebir dersinin öğretimine yönelik tavsiyeleri Carlson (1993) tarafından şu şekilde sıralanmıştır.

1. Lineer cebir ders içeriği farklı disiplinlerin ihtiyacına cevap verecek şekilde düzenlenmeli

2. Lineer cebir dersi en az iki dönemlik bir ders olarak yürütülmeli

3. İlk dönem lineer cebir derslerinde ispata çok fazla vurgu yapılmamalı

4. Lineer cebir derslerinde teknolojiden yararlanılmalı

5. Geometrik temsillerden yararlanmalı

6. Ders içeriği matrislerde işlemler, lineer denklem sistemleri ve çözümü, determinantlar, $\mathrm{R}^{\mathrm{n}}$ de lineer birleşim, lineer bağımsızlık, taban, alt uzaylar, ... şeklinde düzenlenmelidir.

Yukarıdaki öneriler arasında, içinde bulunulan döneme göre en dikkat çekici ve yenilikçi önerilerden birinin, lineer cebir derslerinde teknolojiden yararlanılması fikri olduğunu söyleyebiliriz. Basit fiziksel veya görsel temsillerin olmadığı konularda matematik, öğrenciler için zorlaşabilir. Dubinsky (1997) bilgisayar kullanımının birçok önemli matematiksel nesne ve süreç için somut temsiller sağlamada yararlı olabileceğini ifade etmiştir. Benzer şekilde Amerikan Ulusal Matematik Öğretmenleri Konseyi, 2000 yılında yayımladığı raporunda da teknolojik araçların görsel gücünün, öğrencilerin tek başlarına yapamayacakları görselleştirmeleri kolaylaştırabileceğini belirtmiştir (NTCM, 2000). Bu önerilere paralel olarak birçok araştırmacı lineer cebir öğretiminde teknoloji desteğinin oldukça önemli olduğunu vurgulamakta (Aydın, 2009b; Dikovic, 2007; Dorier, 2002; Harel 2000; Pecuch-Herrero, 2000; Wu, 2004) ve araştırmacılar tarafindan birçok farklı yazılım önerilmektedir. Son on yıl içinde hem bilgisayar cebir sistemleri (BCS) hem de dinamik geometri yazılımlarının (DGY) özelliklerini barındıran yazılımlar ortaya çıkmıştır. Bu yazılımlar arasından dikkat çekenlerden birisi de dinamik matematik yazılımı GeoGebra'dır. GeoGebra, her obje için iki bileşen oluşturmaktadır. Cebirsel bileşen objenin açık, kapalı veya parametrik formdaki denklemini, geometrik bileşen ise objenin grafiksel temsilini ekranda yansıtmaktadır. GeoGebra yazılımı içerisinde bir objenin her iki temsiline de kullanıcı tarafindan müdahalede bulunulabilmektedir (Çekmez, 2013). Matematiksel kavramlara ait hem cebirsel temsilleri hem de grafik gösterimlerini bir arada sunan GeoGebra, bu özelliği sayesinde üst düzey soyut matematik kavramların öğretiminde de etkili bir araç olarak kullanılabilir (Hohenwarter ve Jones, 2007)

Lineer cebirin soyut bir yapıya sahip olmasının yanında farklı temsil dilleriyle beraber farklı tanım ve gösterimleri içeren bir ders olduğunu söyleyebiliriz. Lineer cebir ders içeriğinin yapısına bakıldığı zaman iki çeşit yaklaşımın kullanıldığı görülmektedir. Bu yaklaşımlar Bourbaki stili ve yeni yaklaşım olarak isimlendirilmektedir. Bourbaki stiline sahip ders kitapları genelden özele gidiş takip edilerek hazırlanmıştır (Hillel, 2000). Bu yaklaşımda lineer cebir dersine ilk olarak vektör uzayları teorisi ile giriş yapılıp ardından $\mathrm{R}^{\mathrm{n}}$ deki daha spesifik teori ile devam edilmektedir. Özellikle 1980'li yılların ilk dönemleriyle birlikte birçok eğitimci ve ders kitabı yazarı Bourbaki yaklaşımından vazgeçerek yeni yaklaşımı benimsemeye başlamıştır. Yeni yaklaşımla birlikte lineer cebir dersine sezgisel anlamlar inşa etmek için; geometrik bir formda başlangıç yapılmakta, daha sonra $\mathrm{R}^{2}, \mathrm{R}^{3}, \mathrm{R}^{\mathrm{n}}$ ve $\mathrm{V}$ vektör uzayında kavramların cebirsel ve soyut temsillerine yer verilebilmektedir. Ancak benimsenen yeni yaklaşım geleneksel öğretime dayalı sınıf ortamlarında öğrencilerin vektör uzayı teorisi ile ilgili anlamalarını güçlendirmek konusunda çok da etkili olamamıştır (Dogan, 2001; 
Hillel ve Sierpinska, 1994). Bu nedenle öğrencilerin vektör uzayları kavramlarıyla ilgili daha derinlemesine anlamalara sahip olmaları, teknoloji destekli ve öğrenci merkezli öğrenme ortamlarının tasarlanmasına bağlı olabilir.

Literatürde lineer cebir öğretimine yönelik birçok çalışma yer almaktadır. Hristovitch (2001) öğrencilerin seçmiş olduğu metafor ve analojilerin onları lineer bağımsızlık ile ilgili kavram yanılgılarına götürdüğünü belirtmiştir ki burada sezgisel çıkarımlar etkili olmuştur. Bogomolny (2006) ve Hristovitch (2001) az sayıda öğrencinin kavramsal anlamayı nasıl geliştirdiklerini tartışmıştır. Çelik (2015) ve Doğan-Dunlap (2010) lineer bağımsızlık kavramı ile ilgili öğrencilerin düşünme biçimlerini araştırmayı amaçlamıştır. Çelik (2015), lisans öğrencilerinin lineer bağımlılık/bağımsızlık kavramlarını anlamaları ve bu kavramlarla ilgili öğrencilerin düşünme biçimlerini araştırdığ1 çalışmasında öğrencilerin verilen problemlerin çözümünde daha çok aritmetik veya cebirsel işlemleri kullandıklarını tespit etmiştir. Nardi (1997) ve Stewart ve Thomas (2010), öğrencilerin taban kavramı ile ilgili bilişsel gelişimini, özellikle germe ve lineer bağımsızlık kavramlarından sonra taban kavramının verildiği formal yapıyı dikkate alarak incelemişlerdir. Stewart ve Thomas (2010), lineer birleşim kavramının önemine vurgu yaparak hem germe hem de lineer bağımsızlık kavramları ile yakın ilişkisinden dolayı lineer cebir derslerinde lineer birleşim kavramının öğretimine daha fazla zaman ayrılması gerektiğini ifade etmişlerdir. Donevska-Todorova (2018), teknoloji ile geliştirilmiş bir öğrenme ortamının öğrencilerin yeterliliklerinin gelişimine nasıl katkı sağlayabileceğini araştırmış ve tanımla ve düşünme biçimlerinin iç içe olduğu bir modelin öğrenme ve öğretme ortamları tasarımı için uygun olduğunu önermiştir.

Sonuç olarak, (i) vektör uzayı teorisinin soyut ve teorik doğası (Dorier vd, 1995), (ii) yeni tanımların çokluğu (Dorier vd. 2000; Hillel, 2000), (iii) formalizm sorunu (Dorier, 2000), (iv) küme teorisi, mantık ve ispatla ilgili öğrencilerin eksiklikleri (Britton ve Henderson, 2009; Dorier, 2000; Hillel, 2000), (v) var olan temsil dillerinin özensizce kullanılması (Hillel, 2000), (vi) geometrik temsillere kısıtlı veya yanlış yorumlara neden olacak bir şekilde yer verilmesi (Nardi, 1997; Sierpinska, 2000) ve (vii) üniversite seviyesinde Lineer Cebir derslerinin öğrencilerden kavramlar ve ilişkili prosedürler hakkında belli durumlarda değil en genel durumlarda düşünme ve çalışmalarınının istenmesi (Sierpinska, 2000) Lineer Cebir öğrenme ve öğretme de karşılaşılan temel zorluklardır. Bu zorlukların üstesinden gelebilmek için yapılan öneriler göz önüne alındığında öğrencilerin soyutlama yapmasına imkân veren görselleştirme tekniklerinin ve geometrik temsillerin kullanıldığı, farklı düşünme biçimlerini harekete geçirecek ve öğrencileri bir üst düşünme biçimine taşıyacak ders içi sunum ve etkinliklerin yer aldığı teknoloji destekli zenginleştirilmiş bir öğrenme ortamının tasarlanmasına ihtiyaç vardır. Bu bağlamda çalışmada Lineer Cebir öğretimi üzerine Hillel'in (2000) tanımladığı temsil dilleri, Harel'in (2000) pedagojik prensipleri ve Sierpinska'nın (2000) düşünme biçimleri göz önünde bulundurularak vektör uzaylarının öğretimine yönelik teknoloji destekli bir öğrenme ortamının tasarım ilkelerinin belirlenmesi amaçlanmıştır. Bu amaç doğrultusunda araştırma problemi; "Vektör uzayı konusunun etkili öğretimi için oluşturulacak öğrenme ortamlarının tasarım ilkeleri nasıl olmalıdır?” şeklinde belirlenmiştir.

\section{Yöntem}

Çalışma, tasarım tabanlı araştırma yöntemi ile yürütülmüştür. Tasarım tabanlı araştırmalar; analiz, tasarım, geliştirme ve uygulama süreçlerinin döngüsel olarak yapıldığı, araştırmacılar ve katılımcıların iş birliği içinde gerçek uygulama ortamında gerçekleştirilen eğitim uygulamalarının, tasarım ilkelerinin ve kuramlarının geliştirilmesi amacıyla yapılan sistematik ve esnek bir araştırma yöntemi olarak tanımlanmıştır (Wang ve Hannafin, 2005). Tasarım tabanlı araştırmalar (TTA) diğer tasarım araştırma yöntemlerinden; tasarım - analiz yeniden tasarım aşamalarının etkili bir şekilde döngüsel bir süreç içermesi (Kuzu, Çankaya ve Mısırlı, 2011; Herrington, McKenney, Reeves ve Oliver, 2007) ve katılımcılarla araştırmacıların sürecin başından sonuna kadar aktif rol alması yönüyle farklılaşmaktadır. Ayrıca TTA’lar süreç boyunca yapılan tüm düzenleme ve değişikliklerin ayrıntılı bir şekilde rapor haline getirildiği çalışmalardır (Reeves, 2000). Bu çalışmada öğrenme ortamının tasarım ilkelerinin belirlenmesinde tasarım tabanlı araştırma üç döngü şeklinde gerçekleştirilmiştir.

\section{1. Çalışmanın Tasarımı ve Yürütülmesi}

Çalışmada tasarım - uygulama - geliştirme ve değerlendirme aşamaları üç döngü boyunca gerçekleştirilmiş ve her döngüde yapılan değişiklikler ayrıntılı bir şekilde raporlaştırılmıştır. Böylece her bir döngüden elde edilen veriler gözden geçirilerek, daha başarılı döngüler gerçekleştirmek için düzenlemeler yapılmış ve daha verimli bir tasarım ortaya çıkarılmaya çalışılmıştır. Şekil 1'de tasarım tabanlı araştırmadaki uygulama basamakları akış şeması olarak gösterilmiştir. 


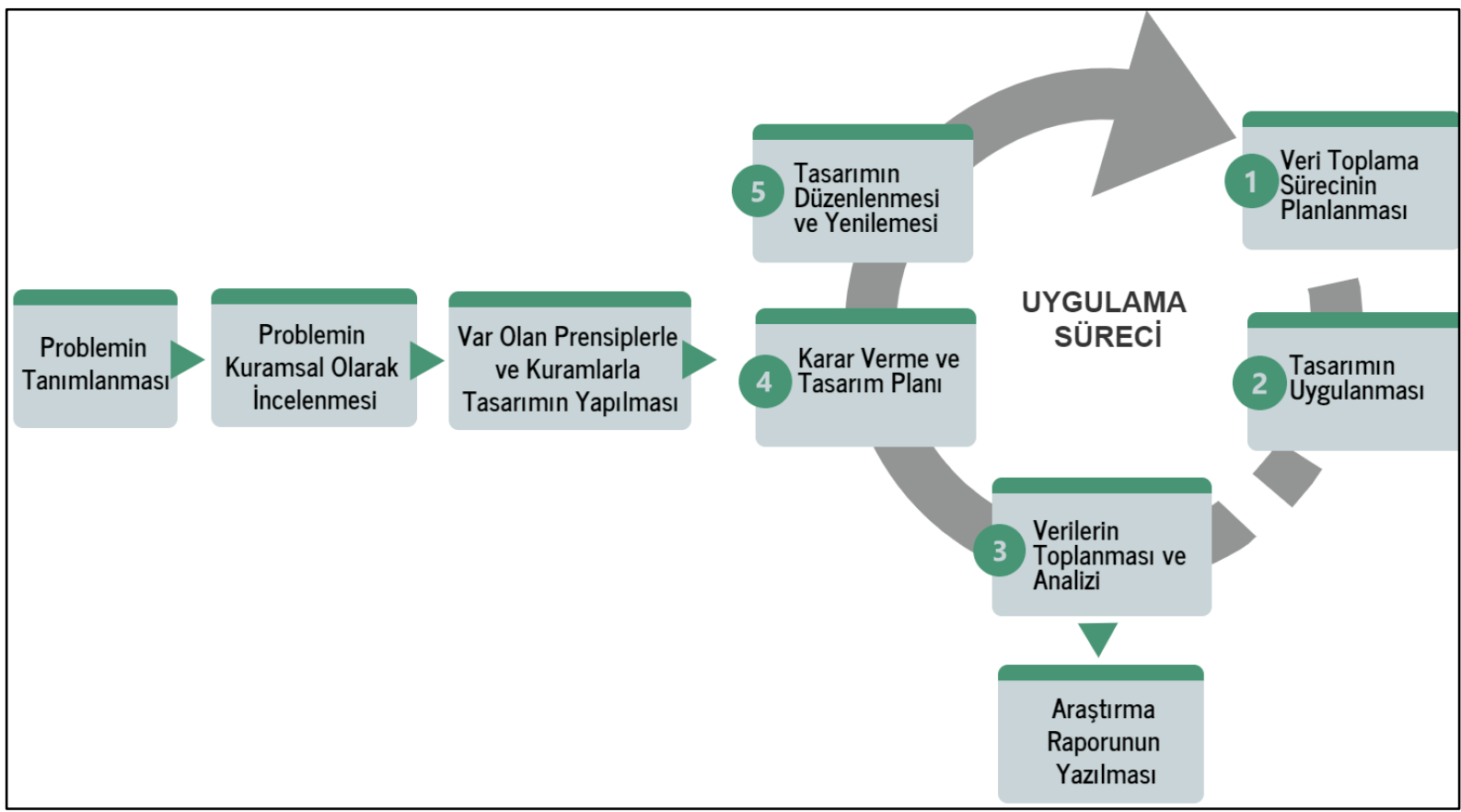

Şekil 1. TTA uygulama basamakları (Kuzu vd., 2011)

Şekil 1'de uygulama sürecinde verilen her bir basamak TTA uygulanan bütün döngülerinde tekrar edilmiştir. Konuyla ilgili yapılan literatür taraması sonrasında vektör uzaylarıyla ilgili öğrenme-öğretme zorluklarına yönelik öneriler dikkate alınarak ve kavramsal çatı ile ortaya konulan ilkeler doğrultusunda öğrenme ortamı tasarlanmıştır. Öğrenme ortamının temel bileşenleri; çalışma yaprakları ve grup çalışması, GeoGebra şablonları ve ödevler olmak üzere üç kısımdan oluşmaktadır. Tasarlanan öğrenme ortamının gerçek sınıf ortamında uygulanabilmesi için vektör uzayları konusu üzerinden 6 haftalık bir uygulama planı oluşturulmuştur. Vektör uzayları ile ilgili her bir kavramın öğretimine yönelik kazanımlar oluşturulmuş, bu kazanımlara ait ders planları hazırlanmıştır. Ders planlarının oluşturulmasında çalışma yaprakları, ödevler ve GeoGebra şablonları hazırlanmıştır. Şekil 2, her bir döngüsü altı hafta süren çalışmanın akış şemasını göstermektedir.

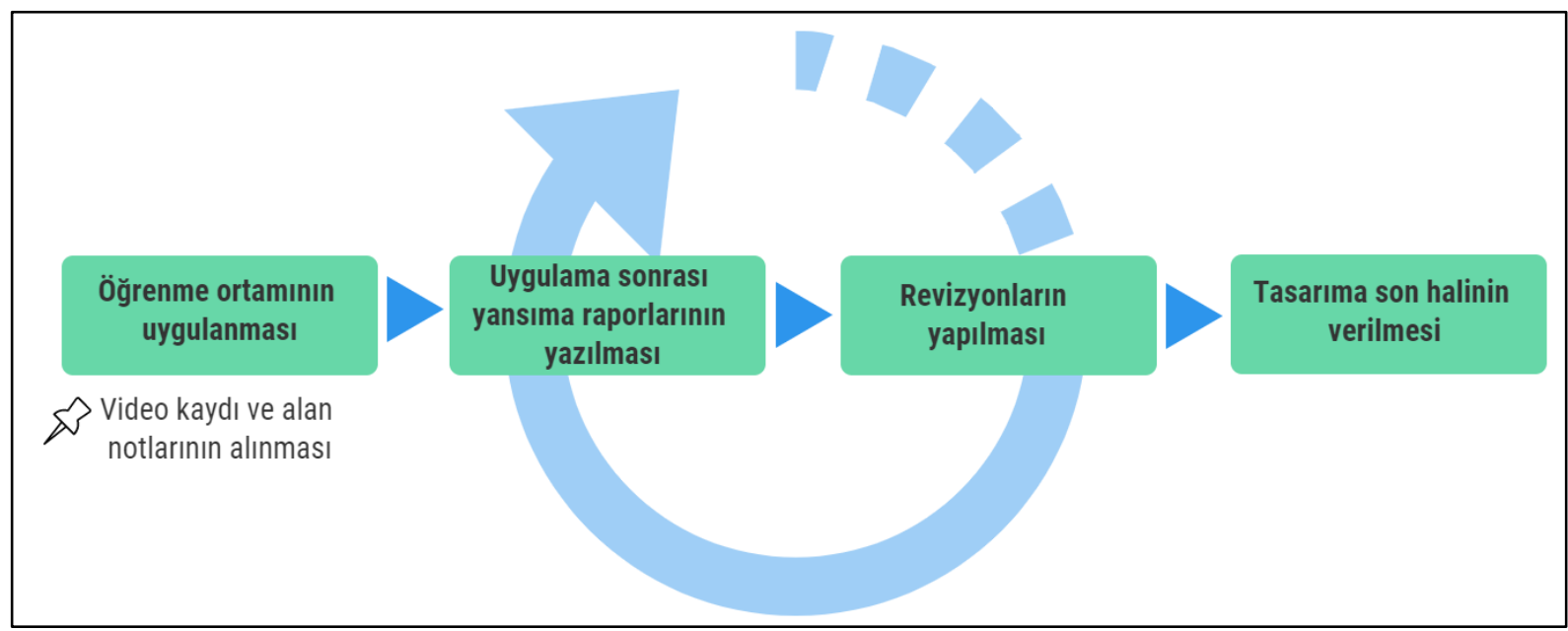

Şekil 2. Araştırmanın yürütülmesi

Şekil 2'de bir haftalık bir süreçte araştırmanın nasıl yürütüldüğü gösterilmiş ve işlemler altı hafta boyunca sürmüştür. Şekil 2'den de görüldüğü gibi öğrenme ortamının uygulandığı dersin hemen sonrasında yansıma raporları tutulmuş ardından bu raporlar ile video kayıt ve alan notlarından elde edilen veriler üzerinden revizyonlar yapılmıştır. Bu revizyonlar, çalışma yapraklarında olan gereksiz soruların çıkarılması, yönergelerin düzeltilmesi, soruların daha anlaşılır bir hale getirilmesi, GeoGebra şablonlarının geliştirilerek daha pratik ve kuramsal altyapıya uygun hale getirilmesi, ders içi sunumların düzenlenmesi şeklinde suralanabilir. Revizyonların yapılmasının ardından araştırmacı, alanında uzman eğitimcilerle birlikte revizyonları değerlendirerek tasarıma bir sonraki döngü için son halini vermiştir. 6 hafta boyunca her ders için aynı süreç işletilmiş ve iki döngü sonrasında tasarım ilkelerini belirlenerek araştırma üçüncü döngü öncesinde hazır hale getirilmiştir. 6 haftalık ders boyunca işlenen konuların listesi aşağıdaki tabloda sunulmuştur. 
Tablo 1. Derslerde İşlenen Konuların Listesi

\begin{tabular}{ll}
\hline Hafta & Konular \\
\hline 1. & Vektör Uzayı \\
\hline 2. & Alt Uzay \\
\hline 3. & Lineer Birleşim \\
\hline 4. & Germe \\
\hline 5. & Lineer Bağımlılık/Bağımsızlık \\
\hline 6. & Taban- Boyut \\
\hline
\end{tabular}

Tablo 1'de yer alan her bir konu haftada 4 ders saati süresinde uygulanmıştır ve dersler çoğunlukla laboratuvar ortamında yürütülmüştür.

\subsection{Katılımcilar}

Çalışma bir devlet üniversitesinde öğrenim gören ortaöğretim ve ilköğretim matematik öğretmenliği programındaki öğrencilerle yürütülmüştür. Çalışma grupları her döngüde farklı sayıda öğrenciden oluşturmaktadır. Aşağıda tabloda döngülerdeki öğrencilerin sayılarına ve çalışmanın yapıldığı tarihlere yer verilmiştir.

Tablo 2. Çalışma Grubu

\begin{tabular}{lcllc}
\hline Döngüler & Öğrenci Sayısı & Tarih & Bölüm & Üniversite \\
\hline 1. Döngü & \multirow{2}{*}{51} & $\begin{array}{l}2016 / 2017 \text { Bahar } \\
\text { Dönemi }\end{array}$ & $\begin{array}{l}\text { İlköğretim Matematik } \\
\text { Öğretmenliği }\end{array}$ & $\begin{array}{c}\text { Karadeniz Teknik } \\
\text { Üniversitesi }\end{array}$ \\
\hline 2. Döngü & \multirow{2}{*}{44} & $\begin{array}{l}2016 / 2017 \text { Bahar } \\
\text { Dönemi }\end{array}$ & $\begin{array}{l}\text { İlköğretim Matematik } \\
\text { Öğretmenliği }\end{array}$ & $\begin{array}{c}\text { Karadeniz Teknik } \\
\text { Üniversitesi }\end{array}$ \\
\hline 3. Döngü & \multirow{2}{*}{11} & $\begin{array}{l}2017 / 2018 \text { Bahar } \\
\text { Dönemi }\end{array}$ & $\begin{array}{l}\text { Ortaöğretim Matematik } \\
\text { Öğretmenliği }\end{array}$ & $\begin{array}{c}\text { Karadeniz Teknik } \\
\text { Üniversitesi }\end{array}$ \\
\hline
\end{tabular}

Bir ve ikinci döngünün çalışma grupları lineer cebir dersini alan 51 kişilik ve 44 kişilik sınıfların üniversite ikinci sınıf öğrencilerinden oluşmaktadır. Dersler bu sınıflarda birer hafta ara ile uygulanmıştır. Vektör uzaylarının öğretimi için tasarlanan öğrenme ortamı birinci döngü olarak 51 kişilik sınıfta uygulanmıştır. Uygulamalar esnasında dersler video kaydına alınmış ve aynı zamanda alan notları tutulmuştur. Video kayıtların tekrar tekrar izlenmesi ve alan notları yardımıyla birtakım revizyonlar yapılmıştır. Yapılan revizyonlar aracı̆̆ıyla bir hafta sonra oluşturulan yeni tasarım 44 kişilik sınıfta uygulanmıştır. Altı haftalık bir süreç boyunca tasarım, her iki sınıfta bu şekilde uygulanmıştır. Araştırmanın üçüncü döngüsü ertesi yıl aynı üniversitede lineer cebir dersini alan ortaöğretim matematik öğretmenliği bölümüne kayıtlı 11 ikinci sınıf öğrencisi ile birlikte yürütülmüştür. İlköğretim ve ortaöğretim matematik öğretmenliği programlarının lineer cebir ders içerikleri arasında bir farklılık bulunmamaktadır.

\subsection{Veri Toplama Araçları ve Verilerin Analizi}

Araştırmanın verileri video kayıtları ile alan notlarından elde edilmiştir. Alan notları, nitel araştırmalarda birincil kayıt aracı olarak kullanılmaktadır. Bu notlar; insanlar, olaylar, etkinlikler ve karşılıklı konuşmalar hakkında bilgilerle dolu; düşünceler, önseziler ve ortaya çıkan örüntülere ilişkin notların alındığı ve araştırmacının gözlemleriyle birlikte bireysel tepkilerini de gözlemleyebileceğimiz bir yerdir (Glesne, 2012; Yıldırım ve Şimşek, 2005).

Araştırmacı ve dersin sorumlusu tarafindan sınıf ortamındaki gözlemlerde alan notları tutulmuştur. Alan notlarında araştırmacı ve ders sorumlusu tarafından gözlem verilerine ve süreç ile ilgili yorumlara yer verilmiştir. Alan notlarıyla süreç boyunca hem tasarlanan öğrenme ortamıyla ilgili ortaya çıkan sorunlar hem de öğrencilerin yaşadıkları zorluklar ve anlamadıkları bölümler rapor haline getirilmiştir. Böylece her bir döngü sonrasında alan notları yardımıyla tasarımla ilgili yapılması gereken değişiklikler ve düzenlemeler yapılarak tasarımın geliştirilmesi hedeflenmiştir. Bununla birlikte her ders boyunca video kayıtları yapılmıştır. Video kayıtları her hafta düzenli olarak kayıt yapılan günlerin tarihleri atılarak bilgisayar ve harici belleğe arşivlenmiş ve uygulama sürecinde veya uygulamadan sonraki zamanlarda bir sonraki döngüde yapılacak olan düzenlemeler için izlenmiştir.

Araştırma kapsamında uygulama öğretmeni ve araştırmacı tarafından tutulan alan notları yardımıyla edilen gözlem verileri, her bir uygulamanın ardından dikkatli bir şekilde gözden geçirilerek transkript edilmiş ve rapor haline getirilmiştir. Oluşturulan ayrıntılı raporlar aracığıyla her bir döngüde tasarımın düzenlenmesi ve gerekli görüldüğü yerlerde değişiklikler yapılması amaçlanmıştır. Video kayıtları da uygulamaların ardından ve gerektiğinde tekrar tekrar izlenerek süreç takip edilmiş ve alan notlarının analizinde yararlanılmıştır. Analizler araştırmanın teorik çerçevesi doğrultusunda lineer cebir öğretimime yönelik pedagojik prensipleri karşılayacak, 
temsil dillerinin kullanıma dikkat edecek ve düşünme biçimlerinin gelişimine katkı sağlayacak şekilde yapılmıştır. Bu şekilde her döngünün sonunda yapılan uygulamaların hikâyeleri oluşturulmuş ve bu hikâyeler doğrultusunda bir sonraki döngü için yapılacak revizyonlar genel hatlarıyla ortaya konulmaya çalışılmıştır.

\section{Bulgular}

$\mathrm{Bu}$ bölümde vektör uzaylarının öğretimine yönelik tasarlanan öğrenme ortamının iki döngü şekilde uygulanması sonucunda elde edilen bulgular, çalışma hikâyesi ve revizyonları başlıklarında ele alınmıştır. Her bir döngüye ait bulgular ayrı ayrı sunulmuştur. İlk iki döngüye yönelik bulgular alan notları ve video kayıtlarının analizinde elde edilen sonuçlar eşliğinde birinci ve ikinci döngüde yapılmasına karar verilen düzenlemeler ve değişiklikler bu bölümde sunulmuștur.

\subsection{Birinci Döngü Tasarım Çalıșması}

\subsection{1. Çalışma Hikâyesi}

Çalışmanın birinci döngüsü 2016-2017 eğitim-öğretim yllının bahar döneminde bir devlet üniversitesinin ilköğretim matematik öğretmenliği programına kayıtlı olan ve lineer cebir dersini alan 51 öğrenci ile gerçekleştirilmiştir. Uygulama vektör uzayları ile ilgili temel kavramlar olan vektör uzay, altuzay, lineer birleşim, germe, lineer bağımlılık, lineer bağımsızlık, taban ve boyut kavramlarını kapsamaktadır. İlk döngüye yönelik uygulamalara başlamadan önce öğrencilere GeoGebra yazılımı iki saatlik bir ders süresince tanıtılmıştır. $\mathrm{Bu}$ iki saatlik ders süresi boyunca GeoGebra programının temel işlevleri gösterilerek özellikle derste kullanılacak bölümlere vurgu yapılmıştır. Öğrenciler GeoGebra programıyla ilgili daha önceden ders aldıkları için iki saatlik uygulama ile ilgili gereksinimler iki saatlik uygulama ile karşılanmıştır. İlk döngüde derslerin bir bölümü sınıf ortamında yürütülürken bir bölümü de laboratuvar ortamında yapılmıştır. Etkinlikler laboratuvar derslerinde öğrenciler ile ikişer kişilik gruplar halinde uygulanmıştır. Ders süresince öğrencilerden GeoGebra yazılımıyla etkileşimli olarak çalışma yapraklarını doldurmaları istenmiştir. Uygulama süresince her derste öğrencilere iki adet ödev verilmiş̧ir. 6 haftalık süreç boyunca bütün dersler video kaydına alınmış ve her bir ders sonrasında araştırmacı tarafından yansıma raporları yazılmıştır. Video kayıtları, yansıma raporları ve araştırmacının gözlemleri dikkate alınarak çalışma yapraklarında, GeoGebra şablonlarında, ödevlerde ve ders içi sunumlarda gerek dillerin kullanımı, düşünme biçimlerinin gelişimi gerekse uygulama sorularının anlaşılması ve zaman yönünden oluşabilecek sıkıntıları ortadan kaldırmak açısından düzenlemeler yapılmıştır.

\subsubsection{Birinci Döngüye Yönelik Program Revizyonu}

Bu bölümde birinci döngü sonrasında tasarlanan öğrenme ortamıla ilgili düzenlemeler işlenen kavramların isimlerinin olduğu başlıklar altında ayrı ayrı verilmiştir.

Vektörler, Vektörel Toplam ve Skalerle Çarpım $\left(R^{2}\right.$ ve $\left.R^{3}\right)$

Vektörler, vektörel toplama ve skalerle çarpım kavramlarının öğretimine yönelik olarak hazırlanan çalışma yaprakları iki bölümden oluşmaktadır. İlk bölümde düzlemde vektörler, vektör ailesi, konum vektörü ve vektörlerin gösterimi konuları, ikinci kısımda ise vektörel toplama ve skalerle çarpım konuları ele alınmıştır.

Etkinliğin ikinci kısmında herhangi bir değişikliğe gidilmemiştir. Birinci kısımda ise hem çalışma yaprağında hem de GeoGebra uygulamasında bazı değişikliklere gidilmiştir. Etkinliğin birinci kısmında öğrencilere hazır bir GeoGebra şablonu verilmiş ve bu şablon üzerinden onay kutularını işaretleyerek geometrik şekilleri oluşturmaları istenmiş̧ir. Ancak bu kısımda değişikliğe gidilerek hazır şablonun yerine geometrik yapıları program aracığıyla öğrencilerin oluşturmasının daha faydalı olacağı düşünülmüştür. Daha önce öğrencilere GeoGebra dersi verilmiş olmasına rağmen uygulamanın ilk etkinliği olması sebebiyle geometrik yapıları öğrencilerin kendilerinin oluşturmasının onlara hem programı daha çok tanıma hem de keşfetme odaklı çalışmalarına olanak sağlayacağı düşünülmüştür. Çünkü ilerleyen süreçte öğrencilerin diğer kavramlara yönelik GeoGebra şablonlarında vektör oluşturmakta zorlandıkları ve araştırmacıdan sürekli yardım almak istedikleri gözlenmiştir. Vektör uzayları konusu boyunca $\mathrm{R}^{2}$ ve $\mathrm{R}^{3}$ de vektör çizimlerinden sıkça yararlanılacağı için öğrencilerin geometrik yapıları kendilerinin oluşturması bu konuda pratik sahibi olmaları açısından önemlidir. Programdaki bu değişikliğe bağl olarak da ilk sorunun yönergesi tekrar gözden geçirilerek değiştirilmiştir. Şekil 3 ’te vektör kavramına yönelik çalışma yaprağının ilk iki sorusunda yapılan değişikliler gösterilmektedir. 


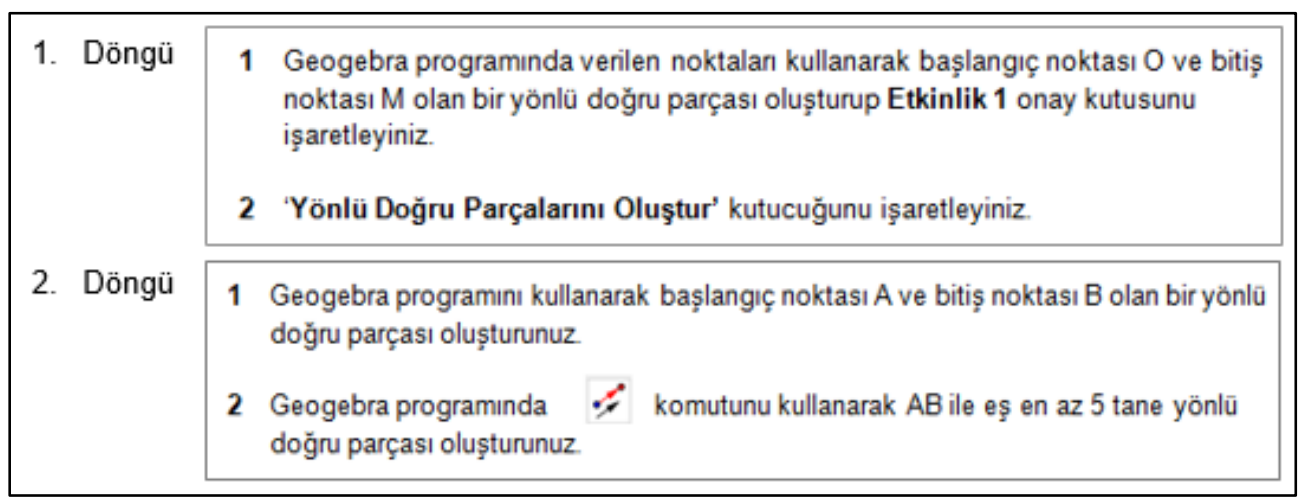

Şekil 3. Birinci döngü sonrasında Etkinlik 1'de yapılan değişiklik

Şekil 3’de görüldüğü üzere birinci döngüdeki çalışma yaprağındaki yönergeler ikinci döngüde gösterildiği gibi düzenlenmiş̧tir. Ayrıca bu bölüme ait etkinlikteki 2. sorunun c şıkkında, uygulamada esnasında öğrencilerin anlamakta biraz zorlandıkları gözlenmiştir. Öğrencilere ikinci sorunun c şıkkında ekrandaki vektör ailesini tek bir nokta ile eşleştirmenin mümkün olup olmadığı sorusu yöneltilmiş ve bazı öğrenciler bu ifadeyle ne anlatılmak istediğini anlamadıklarını ifade etmiştir. Araştırmacı alan notunda bu durumu aşağıdaki gibi özetlemiştir.

"Sorular genel olarak öğrenciler tarafından anlaşılsa da birkaç öğrenci ikinci sorunun c şıkkını tam olarak anlamadıklarını ifade etmiş ve araştırmacı bu kısımla ilgili öğrencilere gerekli açıklamaları yaparak sorunun anlaşılmasında yardımcı olmuştur. Etkinlik 2'nin dört ve beşinci sorularında sırasıyla $\mathrm{R}^{2}$ ve $\mathrm{R}^{3}$ ten birer vektör verilerek öğrencilerden Geogebra programında sürgü oluşturmaları istenmiştir.”

Bu bölümde vektörlerin geometrik gösteriminden çıkarak cebirsel olarak ifade edilmesi ve öğrencilerin analitik-aritmetik bir düşünme yapısına taşınması hedeflenmiştir. Bu amaçla öğrencilere vektör ailesini temsil eden konum vektörü ve onun koordinatları örnek gösterilerek vektör nokta ilişkisini görmelerine rehberlik edilmiştir. İkinci sorunun $\mathrm{c}$ şıkkıyla ilgili çalı̧̧ma yaprağında bir değişikliğe gidilmemesine rağmen bu kısımlar not alınarak bir sonraki döngüde öğrencilere gerekli açıklamaların yapılmasına karar verilmiştir.

\section{Vektör Uzayl ve Altuzay}

Vektör uzayı ve altuzayı kavramlarının öğretimine yönelik olarak hazırlanan uygulama, Etkinlik 1 ve Etkinlik 2 adıyla iki bölümden oluşmaktadır. Birinci bölümde vektör uzayı ikinci bölümde alt uzay kavramları ele alınmıştır.

Çalışma yapraklarında genel olarak çok fazla bir değişikliğe gidilmemiştir. Yalnızca Etkinlik 1 de a, b, c ve d olmak üzere dört şıktan oluşan ilk sorunun a ve $\mathrm{b}$ şıkları birleştirilmiştir. Benzer bir şekilde $\mathrm{a}, \mathrm{b}$ ve $\mathrm{c}$ olmak üzere üç şıktan oluşan ikinci sorunun $\mathrm{a}$ ve $\mathrm{b}$ şıkları birleştirilmiş̧ir. Öğrencilerin soruları okurken anlam bütünlügünü sağlamakta zorlandıkları gözlenmiştir. Araştırmacının bu duruma ilişkin görüşleri aşağıdaki alan notunda sunulmuştur.

"Bazı soruların birkaç şıktan oluşması öğrenciler tarafından farklı sorularmış gibi anlaşıldı. Öğrencilere sorunun ne olduğunu sorduğumda bir öğrenci; "Hocam bunları ayrı ayrı mı oluşturup daha sonra birlikte inceleyeceğiz yoksa tek bir şekil üzerinde mi yapacağız?” şeklinde bir soru yöneltti. Bunun üzerine sınıfta diğer öğrencilerin durumuna bakıldığında benzer bir durumla karşılaşıp ne yapmaya karar vermeye çalıştıklarını gördüm."

Karşılaşılan bu olumsuzluklar nedeniyle ve soruların bütünlüğünün sağlanması amacıyla böyle bir değişikliğe gidilmiştir. Aşağıda Şekil 4'de altuzay etkinliğinin birinci sorusunda yapılan düzenlemeye yer verilmiştir.

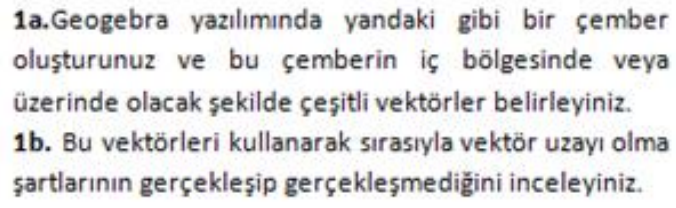
1a.Geogebra yazlımında yandaki gibi bir çember oluşturunuz ve
bu şemberin iş bölgesinde veya üzerinde olacak şekilde şeşitli
vektörler belirleyiniz ve bu vektörleri kullanarak sırasıyla vektör
uzayı olma şartlarının gerçekleşip gerçekleșmediğini inceleyiniz.

Şekil 4. Alt uzay etkinliğinin birinci sorusunda yapılan düzenleme

Şekil 4'de görüldüğü gibi benzer şekilde ikinci soruda değişiklik yapılarak soru düzenlenmiş̧ir. Etkinliklerdeki sorularda bunun dışında değişikliğe gidilmemiş ancak sorular öğrenciler tarafindan anlaşılmış olmasına rağmen etkinlik planlanan süreden daha uzun sürmüştür. Öğrencilerin özelikle ilk iki soruda çizmeleri istenen geometrik yapıları oluşturmakta zaman kaybettikleri gözlenmiş ve rapor edilmişsir. Buna rağmen 
GeoGebra uygulamasıyla ilgili bir değişikliğe gidilmemiş ve ikinci döngüde de benzer bir durum yaşanması durumunda yeniden değerlendirilmesine karar verilmiştir.

\section{Lineer Birleşim ve Germe}

Lineer birleşim ve germe kavramlarının öğretimine yönelik olarak hazırlanan uygulama Etkinlik 1, Etkinlik 2, Etkinlik 3 ve Etkinlik 4 olmak üzere dört bölümden oluşmaktadır. İlk üç etkinlik lineer birleşim kavramının son etkinlik ise germe kavramının öğretimine yönelik olarak hazırlanmıştır.

$\mathrm{Bu}$ etkinliğin uygulanmasında dikkat çeken en önemli hususlar zaman sorunu ve motivasyon kaybı olarak ortaya çıkmıştır. Etkinlikte farklı vektör ve bu vektörlerle ilgili farklı durumların yer alması soru sayısının fazla olmasına neden olmuş bu durumda etkinlik için ayrılan süresinin uzamasına neden olmuştur. Öğrenciler her ne kadar etkinlikte yer alan soruların anlaşılmasında ve çözülmesinde genel olarak zorluk yaşamasalar da sürenin uzaması motivasyonlarının düşmesine neden olmuştur. Araştırmacı alan notunda bu durumu aşağıdaki gibi özetlemiştir.

"Etkinliğin bu bölümünde öğrencilerin cebirsel olarak yöneltilen sorularla daha çok ilgilendiği ve çoğunlukla doğru çözümlerde bulundukları gözlendi. Ancak bazı öğrencilerin çalışma yaprağı ile Geogebra uygulaması arasındaki uyumu tam olarak tutturamadığı gözlendi. Bunun yanında etkinliğin uzun sürmesi ve öğrencilerin sınıfın da kalabalık olmasından dolayı motivasyonlarının düşmesi de bir etken olarak ortaya çıktı. Çalışma yaprağında verilen vektörlerin lineer birleşimlerinin kümesini Geogebra programında bazı öğrencilerin oluşturmasının zaman aldığı ve programla ilgili yöneltilen soruların anlaşılmasında zorlandıkları gözlendi."

Lineer birleşim ve germe kavramları birbiriyle iç içe doğal olarak ilişkili kavramlardır. Bu nedenle bir bütün olarak ele alınarak işlenmesi gerekmektedir. $\mathrm{Bu}$ bakımdan etkinliğin bütünlüğünü koruyacak şekilde sadeleştirmelerin yapılmasına ve etkinliğin daha akıcı olacak şekilde yeniden düzenlenmesine karar verilmiştir.

Bundan sonraki kısımda uygulamadaki sorularla ilgili bir değişikliğe gidilmemiştir. Ancak etkinliğin daha anlaşılır ve akıcı olması için Etkinlik 2 ve Etkinlik 3 kapsadıkları farklı durumlar göz önüne alınarak dört parçaya bölünmüştür. Etkinlik 2, düzlemde tek vektör ve biri diğerinin skaler katı olan iki vektörü içeren durumlara, Etkinlik 3 ise düzlemde farklı iki vektör ile birbirinin lineer birleşimi olarak yazılabilen üç vektörü içeren durumlara odaklanmıştır. Yapılan değişiklikle;

1. Etkinlik 1, tek vektör ve lineer birleşimleri

2. Etkinlik 2, biri diğerinin skaler katı olan iki vektör ve lineer birleşimleri

3. Etkinlik 3, farklı (biri diğerinin skaler katı olmayan)iki vektör ve lineer birleşimleri

4. Etkinlik 4, birbirinin lineer birleşim olarak yazılabilen üç vektör ve lineer birleşimleri olacak şekilde etkinlikler düzenlenmiştir.

Etkinliklerde yer alan sorularda farklı durumlarda vektörlerin geometrik ve cebirsel gösterimlerine yer verilmiştir. Böylece öğrencilerin kavramların farklı temsilleri arasındaki farklılıkları gözlemleyebilmesi ve doğru bir şekilde kullanabilmesi hedeflenmiştir. Video kayıtları ve araştırmacının alan notlarına bakıldığında lineer birleşim ve germe kavramlarının en soyut formda anlaşılabilmesi için geometrik ve cebirsel gösterimlerin anlaşılır ve akıcı bir şekilde sunulmasının gerekli olduğu düşünülmüştür.

Lineer birleşim ve germe kavramlarının öğretimine yönelik olarak hazırlanan GeoGebra şablonu daha çok geometrik yapıları öğrencilerin kendilerinin oluşturacağı şekilde hazırlanmış ve bu durumda bir değişikliğe gidilmemiştir. Etkinliklerle ilgili birinci döngüde yaşanan zaman ve motivasyonla ilgili sorunların devam etmesi durumunda ise GeoGebra şablonunun yeniden gözden geçirilmesine ve etkinliklerin daha akıcı hale getirebilecek bir şablonun tasarlanmasına karar verilmiştir. Bu durumla ilgili alan notları aşağıdaki gibidir:

"Etkinlik boyunca öğrencilerin sorulara cebirsel ve geometrik açıdan baktıklarında doğru cevaplar verdikleri ancak geometrik yaklaşımlarını yeterince gerekçelendirmedikleri gözlendi. Bunun nedeni olarak çalışma yaprağı ile Geogebra uygulaması arasında tam bir etkileşimin sağlanmasının yani öğrencilerin daha çok sorulara cebirsel cevaplar vermeyi tercih etmesinin ve Geogebra programını kontrol amaçlı kullanmalarının etkisi olduğu söylenebilir. Bu problemlerin üstesinden gelmek için etkinliğin biraz daha sadeleştirilmesi ve etkinliğin Geogebra programı ile ilgili sorularının yeniden gözden geçirilerek daha açık bir hale getirilmesi düşünülmüştür.”

\section{Lineer Bă̆ımlılık/Bă̆ımsızlık}

Lineer bağımlılık ve bağımsızlık kavramlarının öğretimine yönelik olarak hazırlanan uygulama tek bir bölümden oluşmaktadır. Etkinliğin bir bütün olarak uygulanmasının etkinliğin anlaşılmasını zorlaştırdığı ve uygulamaya boyunca öğrencilerin zaman zaman sıkılmalarına neden olduğu gözlenmiştir. Bu duruma etki eden bir diğer faktöründe etkinliğe yönelik hazır bir GeoGebra şablonunun olmayışı gösterilebilir. Öğrencilere hazır bir şablon verilmemiş bunun yerine programı kullanarak ihtiyaç duydukları geometrik yapıları oluşturmaları istenmiştir. Ancak birçok öğrenci programı kullanmayı pek tercih etmemiş ve böylelikle çalışma yapraklı odaklı bir etkinlik olmuştur. Bu nedenle özellikle etkinliğin ilk bölümünde somuttan soyuta doğru bir öğrenme gerçekleşmemiş ve programı kullanmayan öğrencilerin direk olarak soyutlamaya kalkışması sorularla ilgili 
varsayım üretmelerini zorlaştırmıştır. $\mathrm{Bu}$ yüzden araştırmacının alan notunda "GeoGebra şablonunun geliştirilmesine ve etkinliğin üç bölüme ayrllarak anlaşılmasının kolaylaştırılması düşünülmüştür” ifadesiyle belirttiği gibi bir bulgu ortaya çıkmıştır.

Yukarıdaki gerek araştırmacının alan notları gerekse video kayıtlarında oluşan öğrencilerin aralarında konuşmaları dikkate alındığında tek bir bölümden oluşan etkinlik ilk olarak üç bölüme ayrılmasına karar verilmiştir. Buna göre;

1. Etkinlik 1, farklı sayıdaki vektör kümelerinin lineer bağımsızlığına yönelik gerekli ve yeter şartların belirlenmesine ilişkin kısım

2. Etkinlik 2, lineer bağımsızlıkla ilgili doğru/yanlış sorularının yer aldığg kısım

3. Etkinlik 3, vektörlerin geometrik gösterimlerinden hareketle lineer bağımsızlıklarının incelendiği kisim

olmak üzere üç bölüme ayrılmıştır. Böylelikle her bir etkinliğin ayrı ayrı uygulanması ve daha anlaşılır hale getirilmesi hedeflenmiştir. Bununla birlikte etkinliklerde yer alan sorularda değişiklikler ve eklemeler yer almiştır.

Etkinlik 1 de yer alan üçüncü ve dördüncü sorularla ilgili değişikliğe giderken öncelikle ikili ve üçlü vektör kümelerinin lineer bağımsızlıklarının inceleneceği örnekler belirlenmiştir. Ardından bu örnekler üzerinden verilen vektör kümelerinin lineer bağımsızlığına yönelik gerekli ve yeter şarta ilişkin öğrencilerin varsayımları sorulmuştur. Aşağıdaki şekilde üçüncü soru ve bu soruda yapılan değişikliklere yer verilmiştir.

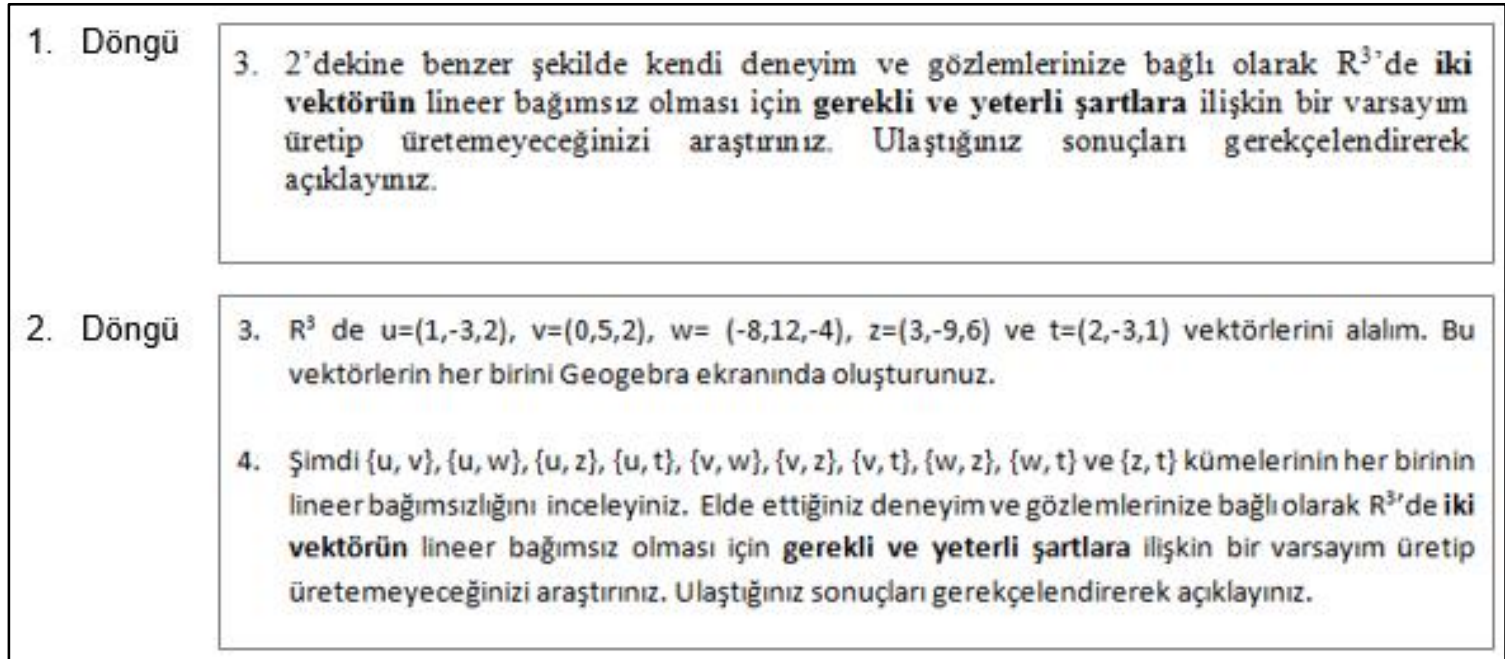

Şekil 5. Lineer bağımsızlık etkinliğinin 3. sorusunda yapılan değişiklik

Şekil 5'de görüldüğü gibi yukarıda bahsedilen değişikliklerin ardından ikinci döngüde yer alacak şekilde düzenlenen soruya yer verilmiştir. Görüldüğü gibi direk olarak iki vektörün lineer bağımsızlığı hakkında öğrencilerin fikirlerini sormak yerine daha önceden belirlenen vektörler verilerek bu vektörlerden oluşan ikili vektör kümeleri üzerinden öğrencilere sorular yöneltilmiştir. Araştırmacı alan notunda bu durumu aşağıdaki gibi özetlemiştir.

"Etkinliğin üçüncü sorusunda öğrencilerin genelde $(1,1,1),(2,2,2)$ gibi örneklerle veya birbirinden olabildiğince farklı $(1,2,3),(5,7,8)$ gibi örnek vektörler üzerinde çalışarak gerekli ve yeter şartlara ulaşmaya çalıştıkları gözlenmiştir. Her ne kadar vektörlerin ne zaman lineer bağımlı ne zaman lineer bağımsız oldukları anlaşılmış gibi görünüyor olsa da bu kısımda ögrenciler lineer bağımsızlıkla kavramı ile ilgili net bir varsayım ortaya koyamamıșlardır. Etkinliğin dördüncü sorusunda $\mathrm{R}^{3}$ te üç vektörün lineer bağımsızlığı ile ilgili kısımda bazı ögrencilerin etkinlikten sıkıldığı gözlendi. Bu etkinlikte öğrencilere Geogebra programı ile ilgili özel bir uygulamama verilmemiş ve öğrencilerden kendi belirledikleri vektörler için programı kullanmaları istenmişti. Ancak birçok öğrencinin programı kullanmadan sorulara cevap vermeye çalıştığı bu sebeple de sorulara geometrik bir yaklaşımda bulunmadıkları gözlenmiştir.”

Araştırmacının alan notlarından hareketle bu kısımda programın keyfi kullanımı zorunluluk haline getirilmiştir. Yapılan değişikliklerle birlikte hem farklı temsiller kullanılarak hem de somut içerik daha etkin bir şekilde sunularak öğrencilerin düşünme biçimlerinin gelişimine katkı sağlaması hedeflenmiştir. Sorularda yapılan bu değişikliklerle birlikte verilen vektör kümelerinin bulunduğu bir GeoGebra şablonu hazırlanmıştır. Öğrencilerin bu GeoGebra şablonunu kullanarak hızlı bir şekilde vektörleri oluşturması ve etkinliğ tamamlaması hedeflenmiştir. Aşağıdaki şekilde GeoGebra şablonuna ait bir resim yer almaktadır. 


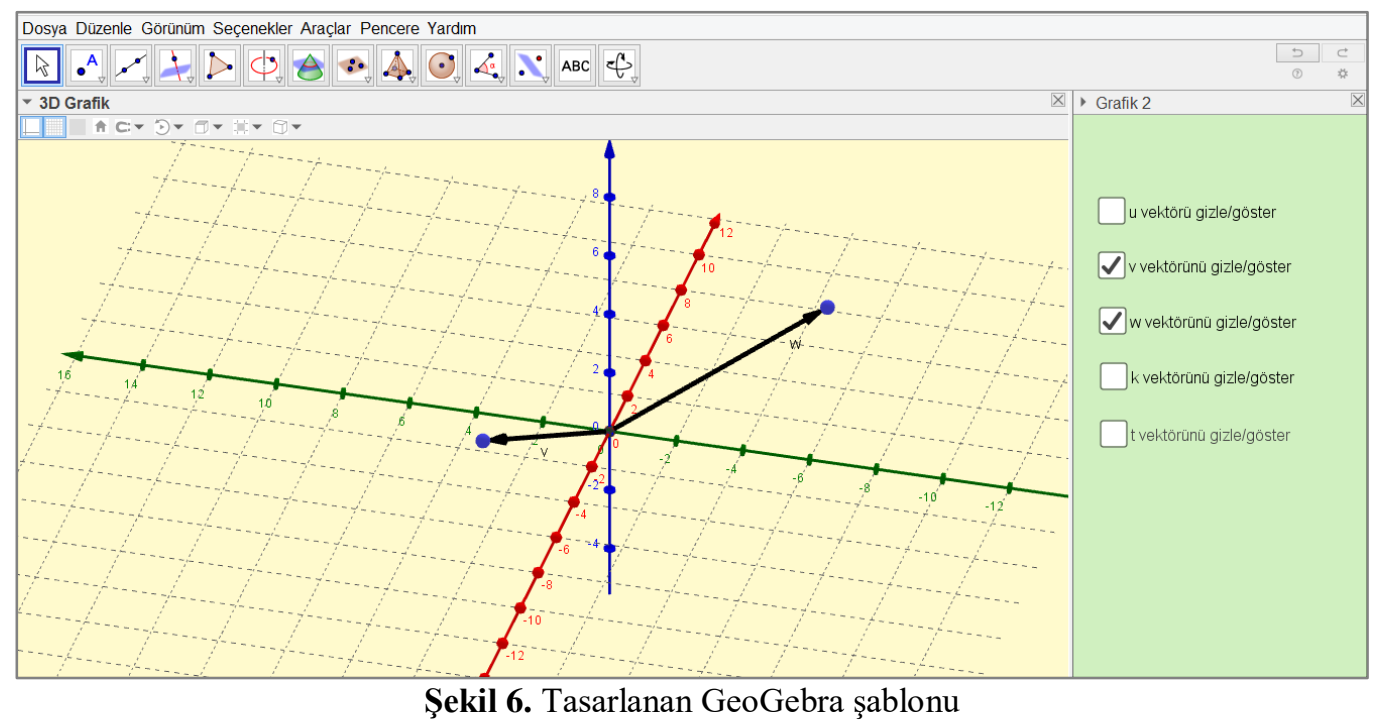

Şekil 6'da görüldüğg̈ gibi ekranın sağ tarafındaki onay kutularını işaretleyerek öğrencilerin istedikleri vektörleri hızlı bir şekilde oluşturmaları hedeflenmiştir.

Lineer bağımsızlıkla ilgili doğru/yanlış sorularının yer aldığı kısım Etkinlik 2 olarak ayrıldıktan sonra bu kısma lineer cebir dersine giren uzman bir eğitimcinin önerisinden konunun daha iyi anlaşılması için bir soru daha eklenmesine karar verilmiş ve "Sıfır vektörünün olduğu her küme lineer bağımlıdır" sorusu eklenmiştir. Etkinlik 1 de sıfır vektörünü içeren bir küme bulunmaktadır ve öğrenciler bu kümenin lineer bağımlılık/bağımsızlığını cebirsel olarak kontrol etmişlerdir. Bu kümenin lineer bağımsızlı̆ı̆ına ilişkin bir sorunun öğrencilerin bu konudaki düşüncelerini öğrenmek açısından eklenmesinin önemli olduğuna karar verilmiştir. Böylece öğrencilerin cebirsel olarak çözüm geliştirdikleri bir durumla ilgili en genel formda nasıl düşündüklerini ortaya koymak amaçlanmıştır. Etkinlik 3'te yer alan düşünülen sorularda ise bir değişikliğe gidilmemiş buna karşın bazı eklemelere yer verilmiş̧ir. Etkinlik 1'de yapılan değişikliklere paralel olarak bu kısımda $R^{3}$ deki vektörlerinde geometrik gösterimlerine yer verilmiş böylelikle öğrencilere hem $R^{2}$ hem de $R^{3}$ deki vektörlerin geometrik gösterimleriyle lineer bağımsızlıkları arasındaki ilişkiyi daha iyi anlama firsatı sunulmuştur. Ayrıca Etkinlik 3'e yapılan eklemelerle sadece $\mathrm{R}^{2}$ deki somut temsillere yer vermekten kaynaklanabilecek kısıtlı öğrenmenin önüne geçilmesi hedeflenmiştir. Aşağıdaki şekilde Etkinlik 3'e eklenen vektörlerin geometrik gösterimlerine yer verilmiştir.

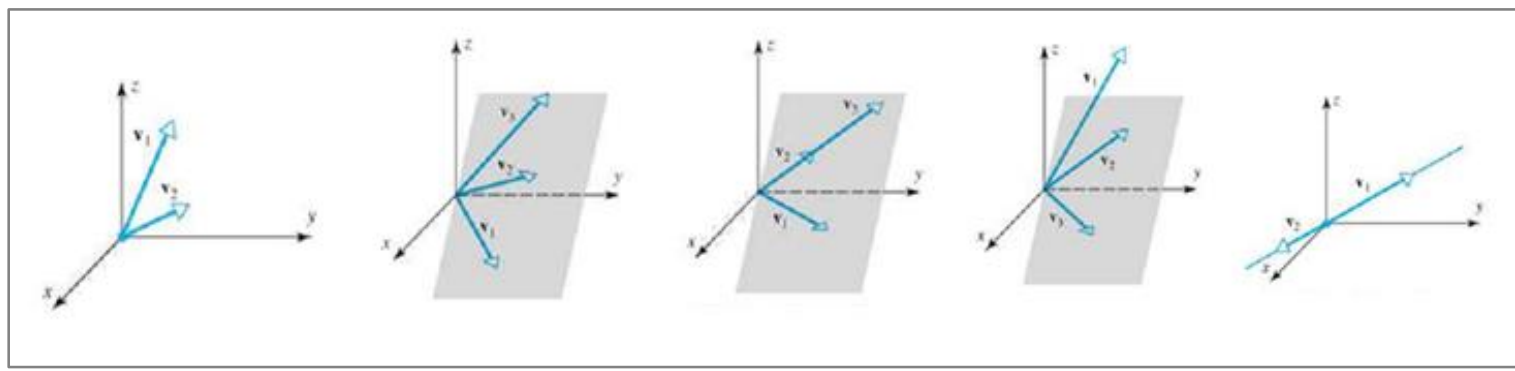

Şekil 7. Lineer bağımlılık/bağımsılzlk etkinliğine eklenen şekiller

Şekil 7'de görüldüğü gibi yapılan bu değişiklik ve eklemelerle lineer bağımlılık/bağımsızlık etkinliği ikinci döngü için düzenlemiştir. Yapılan bu düzenlemenin gerekçesi araştırmacının alan notunda aşağıda verilmiştir.

“Bu bölümde öğrencilerin sorulara doğru ve yanlış cevaplar verdikleri gözlenmiştir. Bazı öğrencilerin $\mathrm{R}^{2}$ de üç vektörün lineer bağımsızlığını geometrik olarak yanlış yorumladıkları bir kısım öğrencilerin ise her ne kadar soruda $\mathrm{R}^{2}$ olarak belirtilmiş olmasına rağmen kendilerine sorulduğunda $\mathrm{R}^{3}$ olarak düşünerek cevapladıkları belirtmişlerdir. Bu yüzden farkın anlaşılması ve her durumda ilişkileri görebilmeleri için $\mathrm{R}^{3}$ örneklerine yer verilmesi uygun görülmüştür."

\section{Taban ve Boyut}

Taban ve boyut kavramlarının öğretimine yönelik olarak hazırlanan uygulama Etkinlik 1 ve Etkinlik 2 olmak üzere iki bölümden oluşmaktadır. İlk etkinlik taban kavramının ikinci etkinlik ise hem taban hem boyut kavramlarının öğretimine yönelik olarak hazırlanmıştır. Etkinlik 1'de $\mathrm{R}^{2}$ nin elemanlarından oluşan 3 adet vektör kümesi verilmiş ve bu vektör kümelerinin $\mathrm{R}^{2}$ vektör uzayının bir tabanı olup olmadığının araştırılması hedeflenmiştir. Ayrıca öğrencilerden GeoGebra programını kullanarak verilen vektör kümelerini çizmeleri istenmiştir. 
Etkinlik 1'deki yer alan sorularla ilgili öğrencilerin anlamadıkları bir bölümle karşılaşılmamıştır. Ancak etkinlikte yer alan soruların kapsamıyla ilgi bir sorunla karşılaşılmıştır. Araştırmacı alan notunda bu durumu aşağıdaki gibi özetlemiştir.

"Etkinliğin ilerleyen kısımlarında öğrenciler tabana ve boyut kavramlarıyla ilgili çıkarımlarda bulunmakta zorlandılar. Verilen kümelerin $\mathrm{R}^{2}$ vektör uzayının tabanlarına yönelik olası bütün durumları kapsamaması bu durumda etkili oldu. Öğrencilerin belli durumlar üzerinden öğrenmelerinin gerçekleştiği sonucuna varılmıştır."

Alan notlarından hareketle öğrencilerin analitik-aritmetik düşünme biçimlerinin gelişimi açısından da çalışma yaprağında birçok farklı durumu karşılayacak şekilde düzenlenmeler yapılmıştır. Bu nedenle ilk olarak birinci soruda verilen küme sayısı üçten beşe çıkarılmış ve diğer olası durumlarda soruya eklenmiştir. Aşağıda şekilde etkinlik 1'in ilk sorusunda yapılan değişikliğe yer verilmiştir.

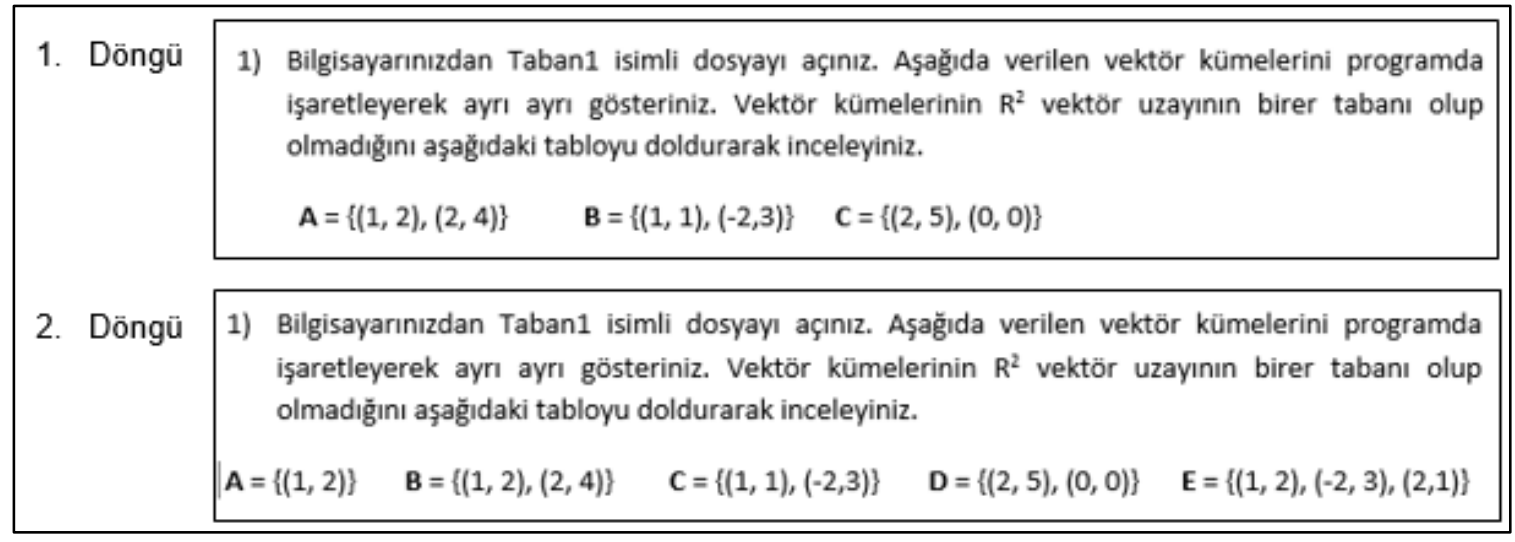

Şekil 8. Taban etkinliğinin 1. sorusunda yapılan değişiklik

Şekil 8'de görüldüğü gibi tek bir elemandan ve üç elemandan oluşan iki vektör kümesi daha eklenerek olası bütün durumlara yer verilmiştir.

\section{2. İkinci Döngü Tasarım Çalışması}

\subsection{1. Çalışma Hikâyesi}

Çalışma üniversite 2. sınıf öğrencileri ile haftada 4 saat olmak üzere 6 hafta boyunca uygulanmıştır. Lineer cebir dersi bir yıllık süreçte verilen bir derstir. Güz döneminde Matris Cebiri bahar döneminde ise Vektör Uzayları Teorisi kısmı verilmektedir. Bu nedenle çalışmanın birinci döngüsü 2016-2017 eğitim öğretim yılının bahar döneminde 44 öğrenci ile gerçekleştirilmiştir. Uygulama, birinci döngüde olduğu gibi vektör uzayları ile ilgili temel kavramlar olan vektör uzay, altuzay, lineer birleşim, germe, lineer bağımlılık, lineer bağımsızlık, taban ve boyut kavramlarını kapsamaktadır. İkinci döngüde dersler birinci döngü ile birer hafta arayla yapılmıştır. İkinci döngüde genel olarak birinci döngü ile benzer basamaklar takip edilmiştir. İlk olarak öğrencilere GeoGebra yazılımı ile ilgili iki saatlik bir ders verilmiştir. Bu iki saatlik ders süresi boyunca GeoGebra programının temel işlevleri hatırlatılmış bununla birlikte özellikle derste kullanılacak bölümlere vurgu yapılmıştır. Derslerin bir bölümü sınıf ortamında yürütülürken bir bölümü de laboratuvar ortamında yürütülmüştür. Etkinlikler laboratuvar derslerinde öğrenciler ile ikişer kişilik gruplar halinde uygulanmıştır. Ders süresince öğrencilerden GeoGebra yazılımıyla etkileşimli olarak çalışma yapraklarını doldurmaları istenmiştir. Birinci döngüde olduğu gibi ikinci döngüde de öğrencilere iki adet ödev verilmiştir. 6 haftalık süreç boyunca bütün dersler video kaydına alınmış ve her bir ders sonrasından araştırmacı tarafindan yansıma raporları yazılmıştır. Video kayıtları, yansıma raporları ve araştırmacının gözlemleri dikkate alınarak tıpkı birinci döngüde olduğu gibi çalışma yapraklarında, GeoGebra şablonlarında, ödevlerde ve ders içi sunumlarda gerek dillerin kullanımı, düşünme biçimlerinin gelişimi gerekse uygulama sorularının anlaşılması ve zaman yönünden oluşabilecek sıkıntıları ortadan kaldırmak açısından düzenlemeler yapılmıştır.

\subsection{2. İkinci Döngüye Yönelik Program Revizyonu}

Bu bölümde ikinci döngü sonrasında tasarlanan öğrenme ortamıyla ilgili yapılan düzenlemelere yer verilmiş ve düzenlemeler işlenen kavramların isimlerinin olduğu başlıklar altında ayrı ayrı verilmiştir.

Vektörler, Vektörel Toplam ve Skalerle Çarpım $\left(R^{2}\right.$ ve $\left.R^{3}\right)$

Vektörler, vektörel toplama ve skalerle çarpım kavramlarının yer aldığı etkinliğin gerek biçimsel olarak düzenlenmesi gerekse her bir konu başlığına ayrı ayrı odaklanılması amacıyla üç bölüme ayrılması planlanmıştır. İki bölümden oluşan ve ilk bölümde vektörler, ikinci bölümde vektörel toplama ve skalerle çarpım kavramlarını içeren etkinlik yapılan değişiklikle; 
1. Vektörler, çalışma yaprağı 1

2. Vektörel toplama, çalışma yaprağ 12

3. Skalerle çarpım, çalışma yaprağı 3

olacak şekilde düzenlenmiştir. Her bir konu başlığına karşılık bir çalışma yaprağı hazırlanarak etkinliği daha anlaşılır ve biçimsel olarak daha düzgün bir hale getirilmesine çalışılmıştır. Bunun dışında vektörler ve vektörel toplama kavramlarını içeren kısımlarında değişikliğe gidilmesine gerek duyulmamış bu kısımda sadece daha sade ve anlaşılır olması açısından bazı soruların soruş biçimi ve yönergeleri değiştirilmiştir. Buna ek olarak GeoGebra programının araç çubuğunda özelleştirme yapılmış etkinlik süresince sadece öğrencilerin kullanacakları özelliklerin araç çubuğunda yer alması düşünülmüştür. Araştırmacı alan notunda bu durumu aşağıdaki gibi özetlemiştir.

"Sınıfta sıraların arasında dolaşırken bazı öğrencilerin konudan bağımsız şekiller çizmeye çalıştıklarını ve konudan uzaklaştıklarını fark ettim. Bazı öğrencilerinde araç çubuğunda ihtiyacı olmayan özellikleri kullanarak zaman kaybettiği gözlendi. Her iki durumun da önüne geçmek için GeoGebra şablonlarında düzenleme yapılması uygun olacaktır."

Video kayıtlarından da araştırmacının bu görüşünü destekleyici bulgular elde edilmiştir. Bu bulgulardan hareketle öğrencilerin araç çubuğunda yer alan ve konu ile ilgili geometrik yapıların oluşturulmasında ihtiyaç olmayan diğer özelliklerle zaman kaybetmesinin önüne geçilmesi hedeflenmiştir. Aşağıda şekilde üst kısımda 1 ve 2. döngülerde kullanılan araç çubuğu alt kısımda 3. döngüde kullanılması düşünülen araç çubuğuna yer verilmiştir.

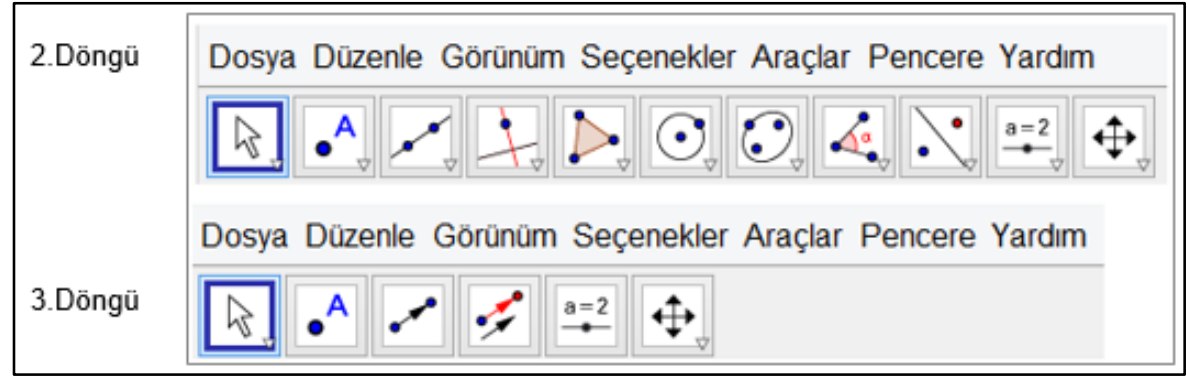

Şekil 9. Geogebra araç çubuğunda yapılan değişiklikler

Şekil 9'da bahsedilen ve daha çok biçimsel olarak yapılan değişikliklerden farklı olarak skalerle çarpma bölümünde soru çıkarılıp soru eklenmesine karar verilmiştir. Bu kısımda öğrencilere $\mathrm{R}^{2}$ den bir vektör verilerek ve bu vektörün bir c reel sayı skaleri ile çarpılmasının GeoGebra programıyla incelenmesi istenmiştir. Ardından aşağıdaki şekildeki soruya yer verilmiştir.

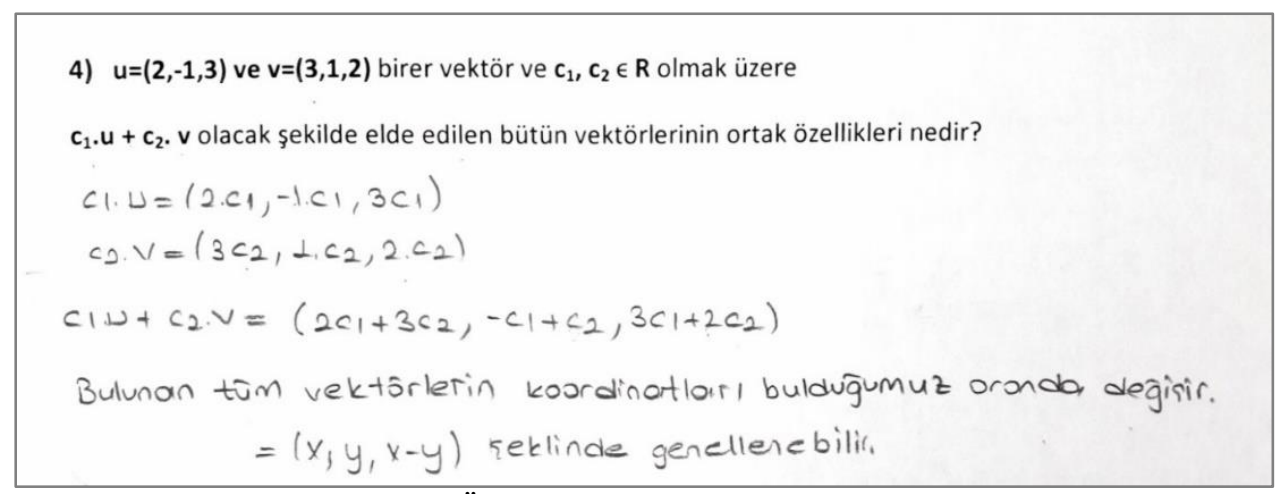

Şekil 10. Öğrencilerin 4. soruya verdiği cevap

Öğrencilerin soruya verdikleri cevaplar çoğunlukla Şekil 10’da gösterildiği gibidir. Aslında soru ile öğrencilerin daha önceki somut deneyimlerinden hareketle vektörel toplama ve skaler çarpma kavramları ile ilgili düşünmelerini (i) analitik-aritmetik düşünme biçimine taşımak, (ii) vektör uzayı kavramı öncesi $\mathrm{R}^{2}$ ve $\mathrm{R}^{3}$ deki vektörlerin toplamının ve skalerle çarpımının yine aynı küme yer aldığı fikrine ulaşmak amaçlanmıştır. Ancak sorunun çözümüyle iki vektörün lineer birleşimlerinin kümesinin elde edildiği ve arzulanan sonuca ulaşılamadığı gözlenmiştir. Çünkü öğrenciler çözümlerinde yalnızca aritmetik işlemlere yer vererek soruda istenilen özelliklere yönelik açıklama yapmamışlardır. Bu nedenle bu sorunun çıkarılarak yerine öğrencilerin somut deneyimlerini artırmak amacıyla $\mathrm{R}^{2}$ de bir vektör ve bir c reel sayı skaleri ile çarpımına benzer bir şekilde $\mathrm{R}^{3}$ ten bir örnek verilmiştir. Aşağıdaki şekilde bu soruya yer verilmiştir. 


\section{GeoGebra'nın 3 boyutlu grafik ekranında $\vec{u}=(3,1,2)$ vektörünü oluşturunuz.}

Yazılımın sürgü komutunu kullanarak $\vec{u}$ vektörü için bir sürgü oluşturunuz. Sürgüyü hareket ettirdiğinizde u vektöründe nasıl bir değişiklik olmaktadır? Grup arkadaşınızla tartışarak ulaştığınız sonucu açıklayınız.

\section{Sürgünün 2 ve -3 değerleri için oluşan vektörleri cebirsel olarak hesaplayınız.} Oluşan vektörleri nasıl elde ettiğinizi açıklayınız.

\section{Şekil 11. Vektörler etkinliğinde 4. soruda yapılan değişiklikler}

Şekil 11'de görüldüğü gibi yapılan değişikliklerin ardından etkinlik biçimsel düzenlenmelerle birlikte 3 . döngüye hazırlanmıştır.

\section{Vektör Uzayl ve Alt Uzay}

Vektör uzayı ve altuzay kavramlarının öğretimine yönelik olarak hazırlanan etkinlerin uygulamasında birinci ve ikinci döngüde karşılaşılan en önemli problem etkinlikler için tasarlanan sürenin üzerine çıkılmış olmasıdır. Vektör uzay etkinliği dört farklı kümenin geometrik gösterimlerinden hareketle vektör uzayı olma şartlarının kontrol edildiği problemleri barındırmaktadır. Her bir kümenin geometrik olarak inşası öğrencilere bırakılmış ve öğrencilerin bu yapıları oluşturması ya zaman almış ya da çizememişlerdir. Bu durumda doğal olarak sürenin uzamasına neden olmuştur.

Öğrencilerin vektör uzayı etkinliğinde yer alan geometrik yapıları oluşturmada yaşadıkları zorlukları aşmak için hazır GeoGebra şablonlarının hazırlanmasının daha uygun olacağına karar verilmiştir. Böylece verilen kümelerle ilişkili geometrik yapıların hızlı ve doğru bir şekilde oluşturulması buna bağlı olarak öğrencilerin sezgisel anlamalarını güçlendirmek hedeflenmiştir. Çünkü öğrenciler yapıları oluşturma da zorluk yaşadıkları gözlenmiş ve bu durum zaman kaybı yaşanmasına neden olmuştur. Ayrıca yaşanan bu zorluklar kavramın öğretilmesinde somut modellere yer verilmesi ve onun üzerinden sezgisel anlamalar oluşturulması amacinı sekteye uğratmıştır. Çizimleri gerçekleştiremeyen bazı öğrencilerin etkinlikleri bırakıp ders öğretmenini beklediği görülmüştür. Bu nedenle her bir problem durumu için sırasıyla Problem1, Problem2, Problem3 ve Problem4 isimleri verilen Geogebra uygulamaları hazırlanarak öğrencilerin vektör uzayı olma şartlarından her birini hızlıca kontrol etmesi amaçlanmıştır. Ayrıca öğrencileri analitik düşünme biçimlerine taşıyacak somut içeriğin doğru olarak araştırmacı tarafindan hazırlanmasının öğrencilerin yanlış somut veriler üzerinden varsayımlarda bulunmasının da önüne geçecektir. Aşağıdaki şekilde Problem1'e ait GeoGebra şablonuna yer verilmiştir.

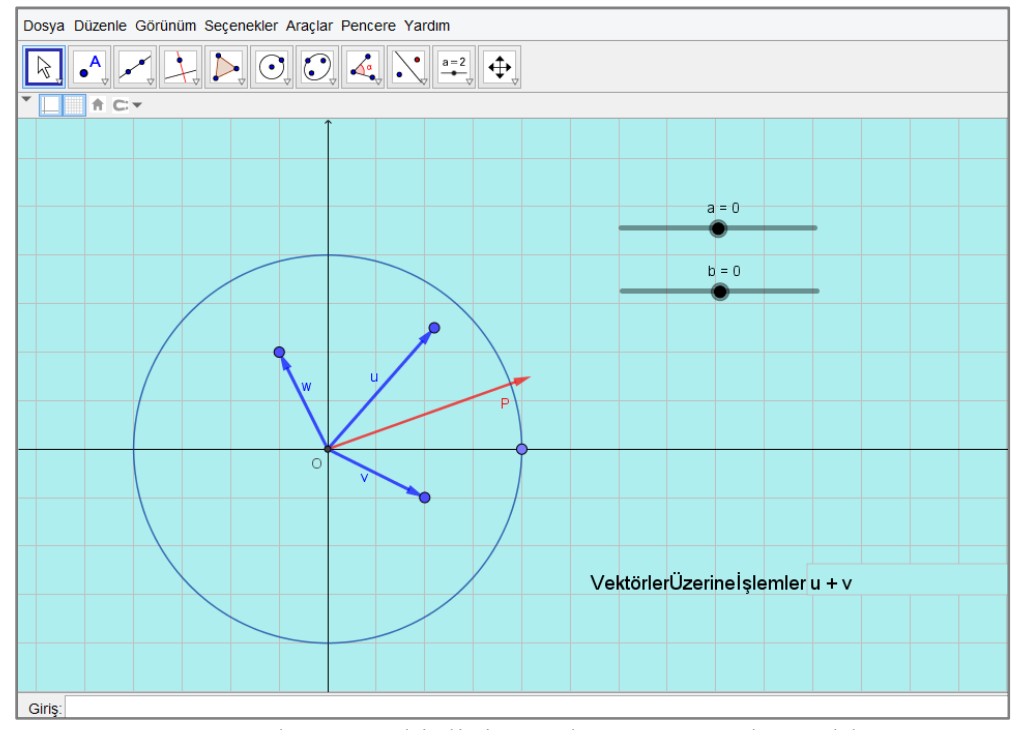

Şekil 12. Alt uzay etkinliği tasarlanan GeoGebra şablonu

Şekil 12'de görüldüğü gibi problemde yer alan geometrik yapı (bu soruda çember), vektörler ve sürgüler öğrencilere şablonla hazır olarak sunulmuştur. Öğrencilerin programda yer alan "Vektörler Üzerine İşlemler" kısmına vektör uzayı olma şartlarını yazarak kontrol etmesi ve programın dinamik yapısını kullanarak somut içeriğe doğru ve hızlı bir şekilde ulaşması hedeflenmiştir. Diğer problem durumları içinde aynı teknik kullanılarak şablonlar oluşturulmuştur. Bununla birlikte "Vektörler Üzerine İșlemler" komutu kavramların 
geometrik ve cebirsel gösterimleri arasındaki bağlantının kurulduğu bir komut olarak işlev görmesi araştırmanın amacına da hizmet etmesi amacıyla GeoGebra şablonunda yer verilmiştir.

GeoGebra uygulaması kısmında yapılan düzenlemelere rağmen etkinliklerde yer alan soruların yapısıyla ilgili değişikliklere gidilmemiş ancak soruların sunuşunda ve etkinliklerin biçimsel formatında öğrencilerde merak uyandırmak ve etkinliği daha akıcı hale getirmek amacıyla düzenlemeler yapılmıştır. Her bir kümeye ait tanımlar ile geometrik gösterimleri bir bütün olarak çalışma yaprağında sunulmuş ve tek bir soru üzerinden kümelerin $\mathrm{R}^{2}$, de tanımlanan standart işlemlere göre vektör uzayı olma şartlarını sağlayıp sağlamadığının öğrenciler tarafında araştırılması istenmiştir. Ayrıca etkinlikte kümelerin cebirsel gösterimlerine de yer verilerek farklı gösterimlere yer verilmesi hedeflenmiştir. Aşağıdaki şekilde yapılan düzenlemelerin ardından çalışma yaprağı 5 'e yer verilmiştir.

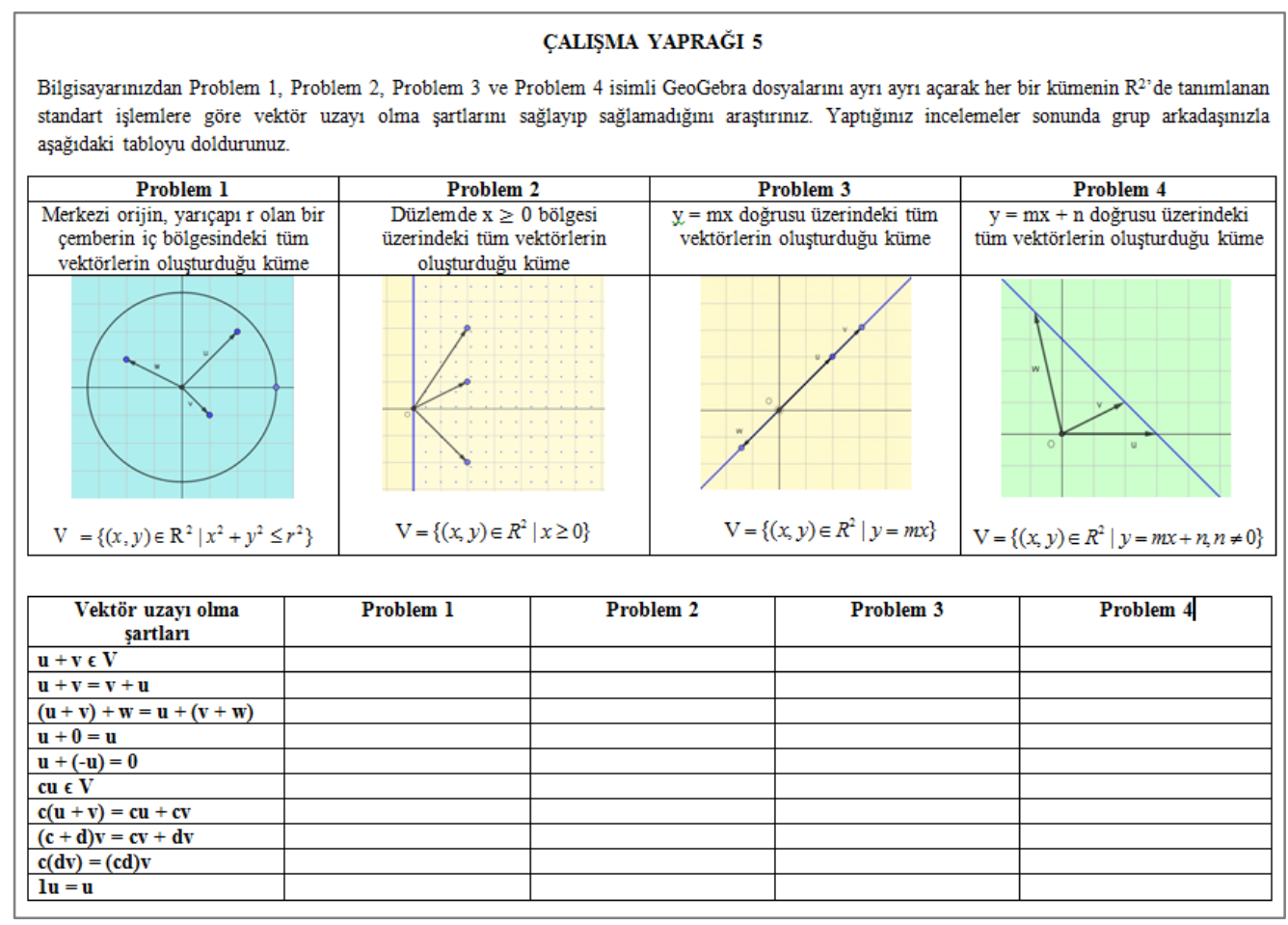

Şekil 13. Yapılan düzenlemelerin ardından çalışma yaprağ 5

Şekil 13'de görüldüğü gibi problemlerin bu şekilde sunularak daha sade ve anlaşılır olmaları amaçlanmıştır. Ayrıca farklı dilleri kullanmaya teşvik etmesi açısından öğrencilere ek kâğıt verilerek geometrik çözümlerinin dışında da varsa farklı çözümler geliştirmeleri istenmiştir. Çünkü öğrenciler genellikle verilen problem durumlarını geometrik çıkarımları kullanarak çözmüş ancak cebirsel çözümler geliştirmedikleri gözlenmiştir. Aşağıda sırasıyla araştırmacının bu konu hakkındaki alan notuna ve örnek öğrenci cevabına ver verilmiştir.

Öğrencilerin Etkinlik 1'de ki sorulara verdiği cevaplara bakıldığında tıpkı ilk grupta olduğu gibi verilen kümelerin vektör uzayı olma şartlarının geometrik olarak sağlayıp sağlamadığına net bir şekilde cevaplar verildiği gözlenmiştir. Ancak çalışma yaprakları üzerinde birçok öğrenci cebirsel olarak cevap vermediği gözlendi.

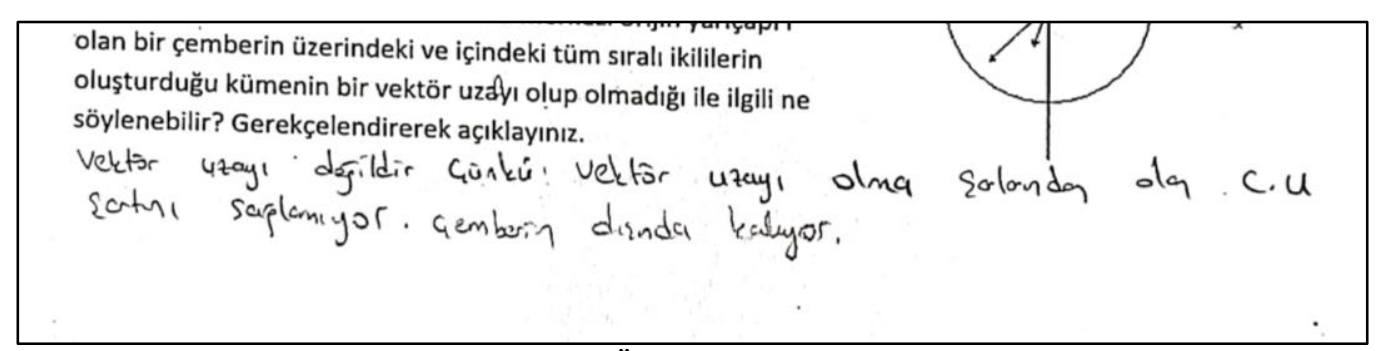

Şekil 14. Örnek öğrenci cevabı

Şekil 14'de görüldüğü gibi öğrenciler kendilerinden cebirsel işlemler yapmaları istenen kısımlarda yapmış oldukları geometrik çözümlere ait betimlere yer vermiştir. 


\section{Lineer Birleşim ve Germe}

Lineer birleşim ve germe kavramlarının öğretimine yönelik olarak hazırlanan etkinliklerin uygulanmasının ardından GeoGebra şablonunda ve etkinliklerde bazı değişiklerin yapılmasına karar verilmiştir. Etkinlikler birinci döngüye oranla daha akıcı bir şekilde uygulanmasına rağmen zamanla ilgili sıkıntının bu etkinlikte de devam ettiği gözlenmiştir. Bu sorunu ortadan kaldırmaya yönelik olarak etkinliği biraz daha sadeleştirmek ve daha anlaşılır kılmak için bazı sorular birleştirilerek yeniden sorulmuştur.

Uygulama esnasında bazı sorularda istenilen geometrik yapıların oluşturulması öğrencilerin zamanını almış bu durumda etkinlik için belirlenen sürenin uzamasına neden olmuştur. $\mathrm{Bu}$ bakımdan birinci döngüde karşılaşılan bu sorun devam etmiş bu nedenle GeoGebra şablonunda değişikliklere gidilmiştir. İlk olarak şablonda biçimsel olarak değişikliğe gidilmiş ve vektörler ile sürgüler ayrı başlıklar altında sunulmuştur. Öğrencilerin birden fazla vektörle işlem yapmaları gereken kısımlarda basit hatalar yaptıkları (yanlış skaler ile vektörün çarpılması, sürgülerin yanlış kullanımı vs.) bu nedenle zaman kaybettikleri gözlenmiştir. Bu basit hataların önüne geçmek ve çok daha kısa sürede geometrik yapıları oluşturmak için GeoGebra şablonuna 'Vektörel İşlemler' adı altında bir girdi alanı eklenmesine karar verilmiştir. Girdi alanı istenilen işlemin cebirsel olarak yazılıp "enter" tuşuna basıldığında geometrik karşılığını ekrana yansıtan bir özelliktir. Aşağıdaki şekilde yapılan düzenlemelerin ardından GeoGebra şablonuna yer verilmiştir.

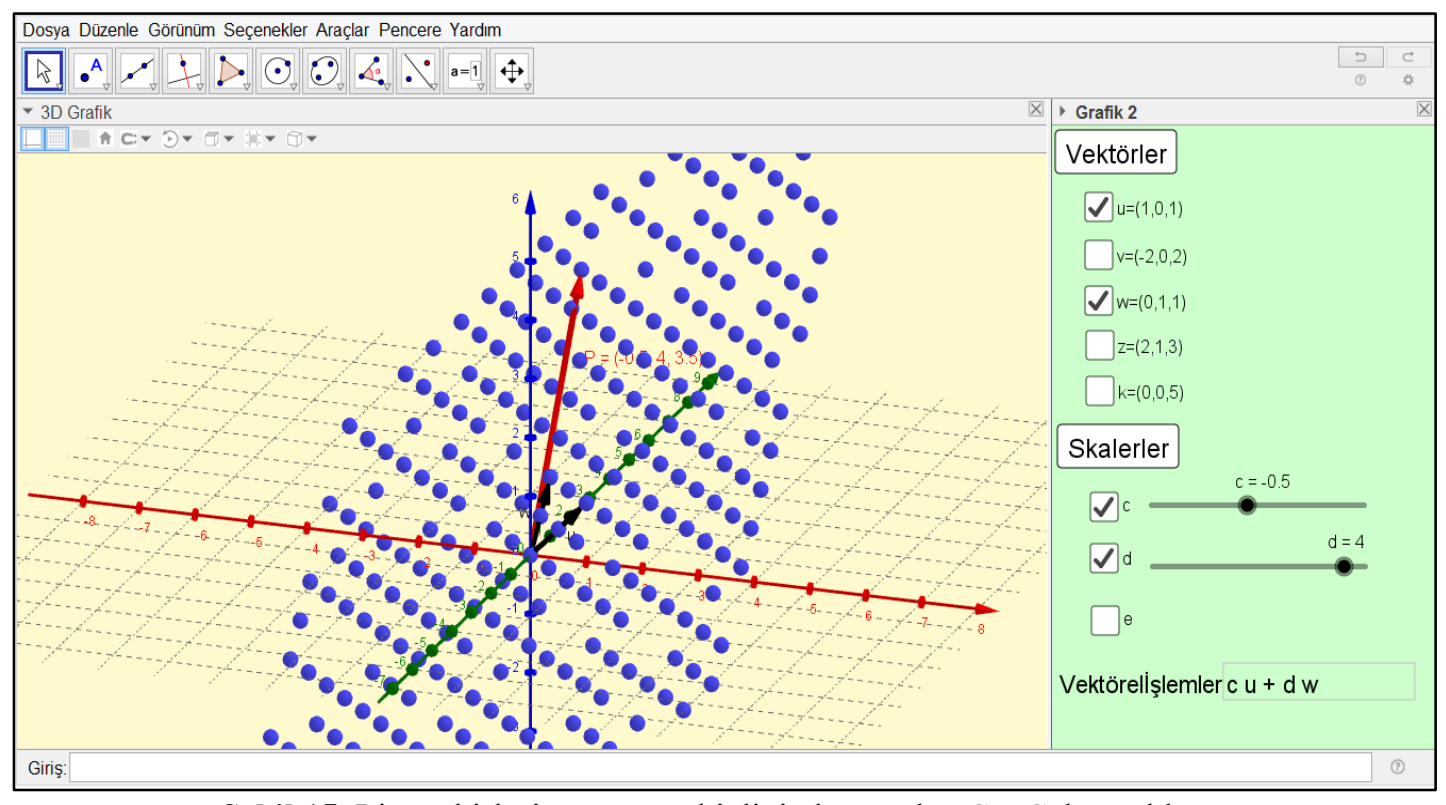

Şekil 15. Lineer birleşim germe etkinliğinde yer alan GeoGebra şablonu

Şekil 15'in sağ alt kısmında yer alan vektörel işlemler alanına “cu $+\mathrm{dw}$ ” ifadesi yazılarak elde edilen vektör ekranda kırmızı bir vektör olarak yansımıştır. Böylece öğrencilerin geometrik şekilleri oluşturmada ve bundan kaynaklanan kavrama ilişkin çıkarımlar yapmakla ilgili yaşadıkları zorlukların üstesinden gelinmesi hedeflenmiştir. Ayrıca etkinliğin uygulama süresinin daha kısaltılması hedeflenmiştir. Yapılan bu değişikliklerin ardından etkinliğe çalışma yaprağ 18 adı verilmiştir.

\section{Lineer Bă̆ımlılık/Bă̆ımsızlık}

Lineer bağımlılık ve bağımsızlık kavramlarının öğretimine yönelik olarak hazırlanan etkinliklerde genel olarak daha çok biçimsel olarak değişikliği gidilmiş ve bununla birlikte bazı sadeleştirmeler yapılmıştır. İlk döngüde hazırlanan etkinlik çok sözel kalmış ve bu yönde bazı değişiklikler yapılmıştı. İkinci döngüde ise sorularda verilen vektör kümelerinin fazla oluşundan dolayı her birinin ayrı ayrı incelenmesinin zaman aldığ 1 ve benzer durumların tekrarlandığı gözlenmiştir. Araştırmacı alan notunda bu durumu aşağıdaki gibi özetlemiştir.

"Birinci gruptaki uygulamanın ardından etkinlikte bazı değişiklikler yapılarak ikinci gruptaki uygulamaya geçilmiştir. Birinci uygulamamızda etkinliğe özgü bir Geogebra uygulaması yer almıyordu. Bunun yerine öğrencilerden Geogebra programını açarak belirledikleri vektörleri kendilerinin çizerek soruya geometrik bir yaklaşım sergilemeleri istenmişti. Ancak öğrencilerin programı çok fazla kullanmayı tercih etmemeleri hem soruya geometrik bir yaklaşımla bakmalarını engellemiş hem de dersin daha çok çalışma yaprağı odaklı geçmesine neden olduğu gözlendi. Bu durumda bazı öğrencilerin dersten sıkıldıklarına dair gözlemlerimiz oldu.”

$\mathrm{Bu}$ bakımdan sorularda öğrencilere lineer bağımsızlıklarını incelemeleri için verilen vektör kümeleri yeniden gözden geçirilerek tekrar eden durumlar belirlenmiş ve sadeleştirilerek en az sayıda vektör kullanarak en etkili şekilde öğrenmenin sağlanması hedeflenmiştir. Örneğin ikinci soruda öğrencilere $\mathrm{R}^{3}$ te beş vektör ve bu beş vektör ile oluşturulacak tüm ikili vektör kümeleri verilmiştir. Yapılan incelemenin ardından 10 tane olan vektör 
kümesi sayısı tekrar eden örneklerin çıkarılmasıyla 6 taneye düşürülmüştür. Aşağıdaki şekilde soru ve soruda yapılan değişikliklere yer verilmiştir.

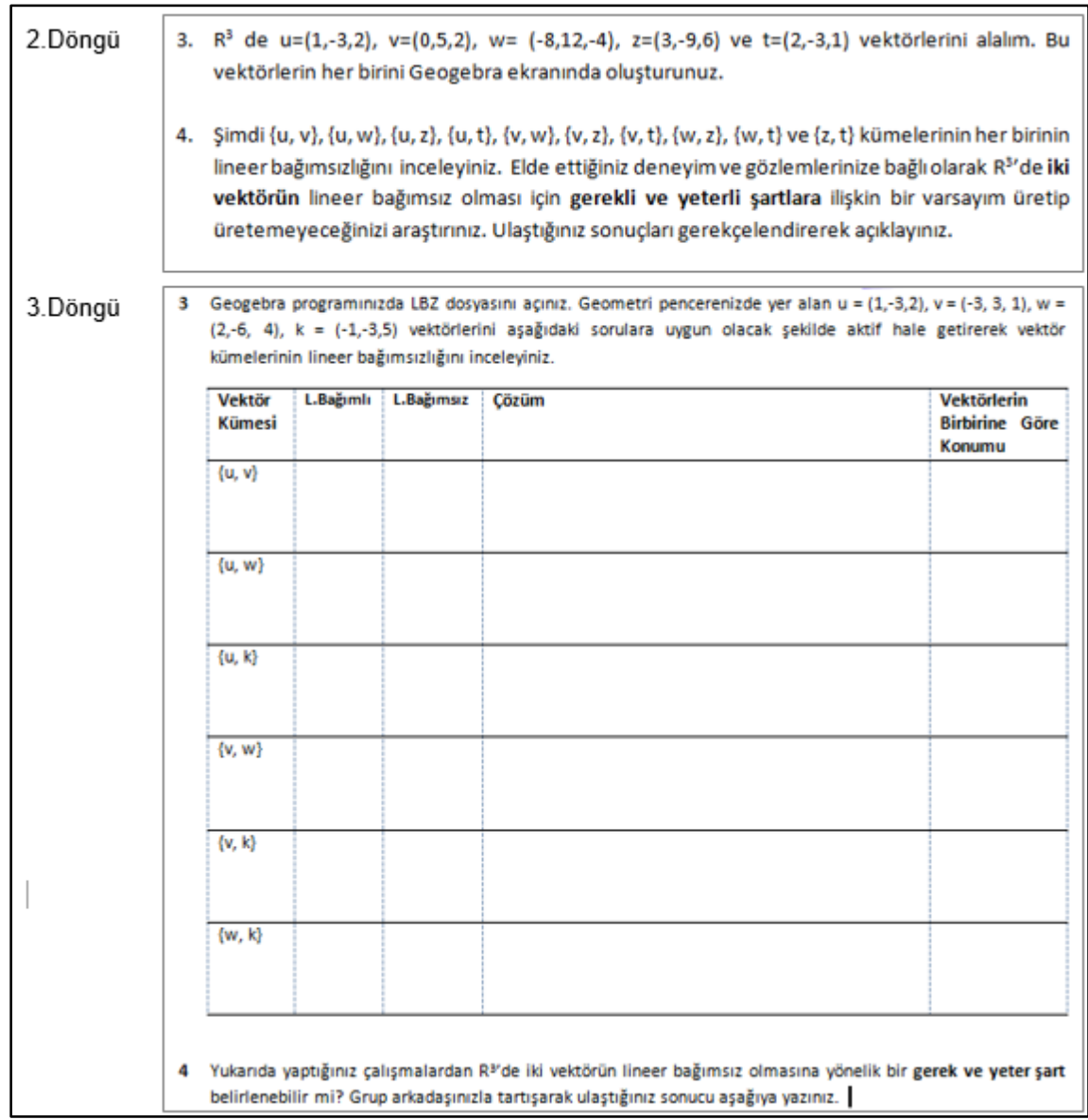

Şekil 16. Lineer bağımsızlık etkinliğinin 3 ve 4. sorularında yapılan değişiklikler

Şekil 16'dakine benzer bir şekilde etkinlikte yer alan 5 ve 6 sorularda değişikliğe gidilerek 6 altı olan vektör kümesi sayısı tekrar eden durumların çıkarılmasıyla 4'e düşürülmüştür. Bunun yanı sıra etkinliğin bu kısmında öğrencilerin karışık bir şekilde not tuttukları ve bu yüzden varsayım üretmede zaman kaybettikleri gözlenmiştir. Aşağıda sırasıyla araştırmacının bu konu hakkındaki alan notuna ve örnek öğrenci cevabına ver verilmiştir.

"Sınıfta dolaşıp öğrencilerin çalışma yapraklarını verdikleri cevapları incelerken işlemlerin çok dağınık bir şekilde birazda acele ile yapıldığı gözlemledim. Buldukları sonuçları birbiriyle ilişkilendirme de zorlanıyor gibiydiler. Hem daha basitçe işlemlerini yapmaları hem de ilişkileri rahatça görebilmeleri açısından çalışma yaprağının biçimsel olarak değiştirilmesi uygun görülmüştür."

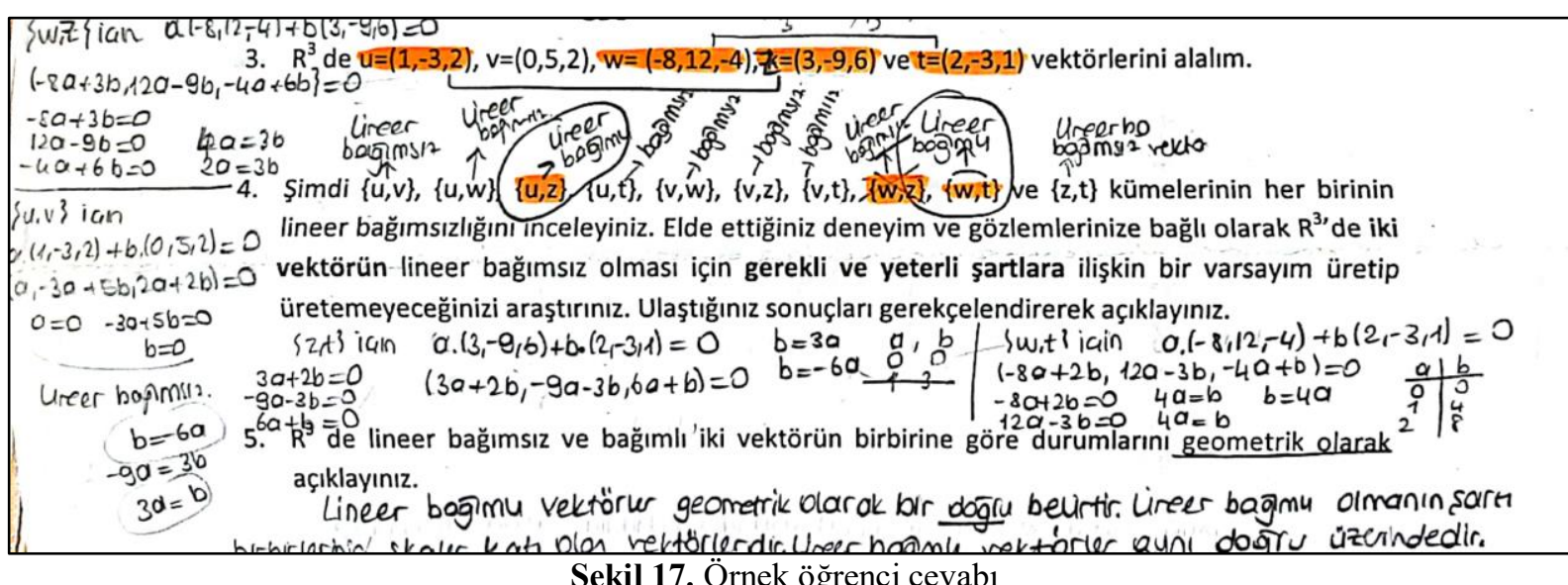

Şekil 17' ye bakıldığında öğrencinin yaptığı çözümlerin karmaşık bir şekilde çalışma yaprağında yer aldığ görülmektedir. Alan notundan hareketle sorular öğrencilerin çözümlerini daha düzenli bir şeklide yapacağı ve yorumlayacakları bir tablo formatında düzenlenerek sunulmuştur. Etkinliğin birinci kısmında yapılan bu değişikliklerin ardından Etkinlik 2 ve etkinlik 3 'te değişikliğe gidilecek bu durumla karşılaşılmamış araştırmacı 
sadece etkinlik 3’te yer alan şekilleri daha profesyonel bir şekilde yeniden çizerek etkinliğe eklemiştir. Ayrıca etkinlik çalışma yaprağı 10 olarak isimlendirilmiştir.

\section{Taban ve Boyut}

İkinci döngünün uygulanmasından sonra taban ve boyut kavramına yönelik olarak hazırlanan etkinliklerde gerek biçimsel olarak gerek içerik olarak bazı düzenlemelere yer verilmiştir. Doğru yanlış sorularının yer aldığı etkinlik 2 kısmında bir değişikliğe gidilmemiş̧ir. Bütün düzenlemeler etkinlik 1'de gerçekleştirilmiştir. Aşağıda araştırmacının uygulamaya ilişkin alan notlarına yer verilmiştir.

"Uygulama boyunca öğrencilerin zorlandıkları herhangi bir durumla karşılaşılmadı. Bir önceki döngüde Etkinlik 2'ye olası bütün durumları içermesi bakımından R3 den örnekler eklenmişti ve bu uygulamada örneklerle ilgili bir problem yaşanmadığı gözlendi. Aynı gerekçelerle Etkinlik 1'de R3 örnek durumların eklenmesinin uygun olacağı düşünülmüştür."

Alan notlarından hareketle öğrencilerin taban ve boyut kavramıyla ilgili öğrenmelerinin yalnızca $R^{2}$ vektör uzayı ile sınırlı kalmaması ve daha sağlıklı bir şekilde genelleme yapabilmeleri için etkinlik 1 'e $\mathrm{R}^{3}$ vektör uzayına ait vektör kümelerinin de eklenmesine karar verilmiştir. $\mathrm{R}^{3}$ vektör uzayının taban olma durumlarının inceleneceği kümeleri belirlerken $\mathrm{R}^{2}$ de olduğu gibi olası bütün durumları içerek kümeler seçilmiştir. Son olarak Etkinlik 1 ve Etkinlik 2 birleştirilerek Çalışma yaprağ 11 adıyla son halini almıştır.

\section{3. Üçüncü Döngü Çalışma Hikâyesi}

Çalışmanın üçüncü döngüsü 2017-2018 eğitim-öğretim yılının bahar döneminde bir devlet üniversitesinin ortaöğretim matematik öğretmenliği programına kayıtlı olan ve lineer cebir dersini alan 11 öğrenci ile gerçekleştirilmiş̧tir. Uygulama vektör uzayları ile ilgili temel kavramlar olan vektör uzay, altuzay, lineer birleşim, germe, lineer bağımlılık, lineer bağımsızlık, taban ve boyut kavramlarını kapsamaktadır. Uygulamaya başlamadan önce GeoGebra programının uygulama boyunca kullanılacak fonksiyonları öğrencilere tanıtılmıştır. Derslerin büyük bir bölümü laboratuvar ortamında yürütülmüştür. Etkinlikler laboratuvar derslerinde öğrenciler ile ikişer kişilik gruplar halinde uygulanmıştır. Ders süresince öğrencilerden GeoGebra yazılımıyla etkileşimli olarak çalı̧̧ma yapraklarını doldurmaları istenmiştir. Uygulama süresince her derste öğrencilere iki adet ödev verilmiştir. Araştırmanın bu döngüsü alanında uzman bir matematik eğitimcisi tarafından yürütülmüş ve araştırmacı gözlemci rolünü üstlenerek video kaydı ve gözlem notları tutmuştur.

Tasarlanan öğrenme ortamı ile ilgili ilkeler üçüncü döngü öncesinde Teknoloji Kullanımı, Temsil Dilleri, Ödevler, Çalışma Yaprakları ve Grup Çalışması olmak üzere beş ana başlık altında toplanmıştır. Araştırmanın üçüncü döngüsünde elde edilen bulgular sonucunda Ders Öğretmenin Rolü altıncı bir başlık olarak tasarım ilkelerine eklenmiş̧ir. Böylece tasarlanan öğrenme ortamı ile ilgili ilkelerin altı başlık altında toplanmasına karar verilmiştir. Ders öğretmeninin rolüne yönelik ilkeler aktif, işbirlikçi, yapının farkında, herkese eşit ve etkileşim içerisinde olarak belirlenmiştir. Tasarım tabanlı araştırmaların doğasına uygun olarak araştırmacılar süreç içerisinde aktif ve işbirlikçi bir tutum içerisindedir. Ancak ders öğretmeninin rolünün her zaman bunlarla sinırlı olmadığ1 alan notları ve video kayıtlarında ortaya çıkmıştır. Ders öğretmeninin bütün öğrencilere söz hakk1 vermesi öğrencilerin ve araştırmacının dikkatini çeken bir durum olarak ortaya çıkmıştır. Araştırmacı alan notunda bu durumu aşağıdaki gibi özetlemiştir.

“Öğrencilerin özellikle ders öğretmeninin tutumundan duydukları memnuniyet oldukça dikkat çekici. Ders sorumlusu sürekli olarak sıralar arasında gezerek öğrencilere rehberlik yapıyor. Bazı öğrenciler bu durumuna yönelik memnuniyetlerini ders içerisinde direk hocalarına belirttikleri de gözlendi. Öğrencilerden biri ile ders sorumlusu arasında geçen bir diyalogda hoca sürekli ortalarda dolaştı̆̆ından dolayı herkes eşit şekilde muamele görebildi ifadesini kullandi."

Üçüncü döngü sonrası ders öğretmenin rolünün öğrenme ortamıyla ilgili ilkelere bir başlık olarak eklenmesine ek olarak bulgulardan hareketle diğer başlıklar altında bazı ilkelere yer verilmiştir. Teknoloji kullanımına dikkat çekme, pratik olma ve formal tanım ve ispatlara hazırlama, ödevler başlığına tartışma ve dönüt verme, çalışma yaprakları başlığına ise pratik olma ilkeleri eklenmiştir. Özellikle ödevlerde yer alan sorular üzerinden sınıfta yapılan tartışmalar ve dönütler öğrencilerin anlamalarında ve düşünme biçimlerinin gelişimde etkili olmuştur. Aşağıda ders öğretmenin bu duruma ilişkin alan notuna yer verilmiştir.

“.......̈̈rneğin bir öğrencinin belli bir soru için $\mathrm{R}^{2}$ veya $\mathrm{R}^{3}$ de çözüm yapsak olmaz mı şeklindeki sorusuna, genel düşünülmesi ve cevap verilmesi şeklinde sınıftan diğer bir iki öğrenciden yanıt geldi. Hatta burada $\mathrm{R}^{2}, \mathrm{R}^{3}$ ve $\mathrm{R}^{\mathrm{n}}$ arasındaki ilişkiye dair öğrencilerin sahip olduğu yanlış anlamlandırma ortaya çıktı. Bu bana bu konu hakkında konuşma firsatı verdi. Bu süreç kayıt altına alındığından burada geçen diyaloglar dikkatli bir şekilde analiz edilebilir. Ödevlerle ilgili bu hareketli tartışma ortamı spesifik ödev verme ve takibinin ne kadar etkili olduğunu bir kez daha göstermiş oldu."

Ders öğretmeninin alan notuna bakıldığında sınıftaki tartışma ortamının öğrencilerin yanlıs anlamalarının ortaya çıkmasında ve bu yanlışların düzeltilmesinde etkili olduğu ortaya çıkmıştır. Ödevlerden farklı olarak öğrenme ortamında kullanılan GeoGebra şablonları ve çalışma yapraklarının uygulanmasında bir sorunla 
karşılaşılmamış ve öğrenciler tarafından pratik bir şekilde kullanıldıkları gözlenmiştir. Özellikle ilk iki döngüde yapılan revizyonlar bu pratikliğin oluşmasında etkili olmuştur. Bununla birlikte belirlenen ilkeler doğrultusunda öğrenme ortamı üçüncü döngüde başarı ile uygulanmıştır. Aşağıda araştırmacının bu konuya ilişkin alan notuna yer verilmiştir.

"Derste yürütülen uygulamanın oldukça verimli olduğunu ve öğrenciler açısından istenilen amaca ulaştı̆̆ını söyleyebilirim. Etkinliklerde yer alan soruların sunuş şeklinde veya anlaşılmalarında herhangi bir sorunla karşılaşılmadı. Böylelikle uygulama benim, ders hocasının ve öğrencilerin aktif olduğu, öğrencilerin motivasyonunun düşmediği bir ders ortamında verimli bir şekilde gerçekleştirilmiş oldu. Hatta derse diğer arkadaşları kadar sık katılmayan iki erkek öğrenci de dersin başından sonuna kadar etkinliklerle ilgilenmiş, sorular sormuş ve çoğunlukla doğru çıkarımlarda bulunmuştur. Bu, tasarlanan ortamın öğrencilerin nasıl ilgisini çektiğini ve onları nasıl motive ettiğinin açık bir kanıtıydı bence."

Araştırmacının alan notlarına ek olarak ders öğretmeninin alan notlarında birbiriyle paralel görüşlerin aktarıldığı görülmüştür. Aşağıda ders öğretmeninin öğrenme ortamına ilişkin alan notlarına yer verilmiştir.

\begin{abstract}
"Genel anlamda öğrencilerin derse katılımı ilgisi iyi. İlk başta çalışma yaprakları ile dersi işleme komsundaki acemiliklerini artık iyice atmışlardı. Derste önceki konulardan bilgilere ihtiyaç olduğunda zorlanmadan çağırabildiklerini fark ettim. Hatta sınıf içi tartışmalarda ya da sınıfa dönük sorularıma cevap verirken ya da verdikleri yanlış cevabı değiştirirken sanki sınıf içinde yaşadıkları deneyimleri gözlerinin önüne getirmeye çalışıyorlar hissi veriyorlardı zaman zaman. Bu uygulamaların genel anlamda verimli geçtiğini düşünüyorum sonrasında yazdığımızı teoremlerin yapısını ve ispatını anlama süreçlerini kolaylaștırıyordu. Ayrıca derse karșı çok ilgisiz görünen öğrenciler bile ders içi yürütülen uygulamalara dahil oldular. Kendilerini diğer derslerde olduğu gibi dışarda bırakmadılar."
\end{abstract}

Öğrenme ortamının başarılı bir şekilde uygulanmasında ders öğretmeninin öğrenme ortamında yürütülen mevcut yapıya hakim olması ve süreci iyi bir şekilde yönetmesinin etkisi vardır. Ders öğretmeni ve araştırmacı ders önceleri ve sonraları bir araya gelerek öğrenme ortamının sağlıklı bir şekilde uygulanması için küçük toplantılar yapmışlardır. Öğrenme ortamının başarısında grup çalışmasının da etkili olduğu düşünülmektedir. Laboratuvar ortamında işlenen dersler grup çalışması şeklinde yürütülmüştür. Grup çalışması başlı̆ı altında ilkeler öğrenci merkezli, tartışmaya olanak sağlayan ve öğrencilerin motivasyonlarını artıran ilkeler olarak şekillendirilmiştir. Öğrencilerle yapılan diyaloglar ve ders içindeki performansları göz önünde bulundurulduğunda grup çalışmalarının öğrencilerin sorumluluklarını ve özgüvenlerini artırdığı ortaya çıkmıştır. Ayrıca öğrenciler grup çalışması şeklinde derslerin işlenişi eğlenceli bulmuş ve laboratuvar derslerini normal sınıf derslerine tercih ettiklerini ifade etmişlerdir. Bulgulardan hareketle bu tercihte grup çalışması yapıyor olmanın etkisinin olduğu düşünülmektedir. Aşağıda araştırmacının bu konuya ilişskin alan notuna yer verilmiştir.

\footnotetext{
"Ders ve etkinlik oldukça verimli ve anlaşılır geçtiği gözlendi. Özellikle öğrencilerin ders içerisinde kendi fikirlerini ortaya koymaları, sorular sormaları ve etkinlikten hareketle çıkarımlarda bulunarak çözüm arayışında olmaları onları dersin aktif bir parçası haline getirdi. Ders bütünüyle laboratuvarda işlendiğinde sadece ders sonuna doğru öğrencilerin yoruldukları gözlendi. Bazı öğrenciler normal sınıf ortamında çok yorulduklarını laboratuvar derslerinin daha keyifli ve az yorduğunu ifade ettiler. Bu durumda formalizmin öğrencileri zorladığını bir kez daha ortaya koymuştur."
}

$\mathrm{Bu}$ duruma paralel olarak video kayıtları incelendiğinde benzer bir durumla karşılaşılmıştır. Sınıf ortamındaki bir derste ders öğretmeni ve öğrenciler arasında geçen bir diyalogda öğrenciler sınıfta zaman zaman sıkıldıklarını ve laboratuvarda derslerini yapmak istediklerini belirtmişlerdir. Ders öğretmeninin neden laboratuvarda ders yapmak istediklerini sorması üzerine zamanın çabuk geçmesi ve grup çalışmasını gerekçe olarak vermişlerdir.

\title{
4. Tartışma
}

Çalışmada lineer cebir öğretimine yönelik olarak literatürdeki zorluklar ve öneriler belirlenerek bir kuramsal çerçeve oluşturulmuş ve bu çerçeve doğrultusunda bazı prensipler belirlenerek bir öğrenme ortamı tasarlanmıştır. Tasarlanan öğrenme ortamı tasarım tabanlı araştırma kapsamında üç döngülük bir uygulama tasarım ve değerlendirme sürecine tabi tutulmuştur. Araştırmanın üçüncü ve son döngü öncesinde alan notları ve video kayıtları kullanılarak tasarlanan öğrenme ortamıyla ilgili ilk iki döngü boyunca düzenlemeler ve değişiklikler yapılmıştır. İlk iki döngü sonrasında yapılan revizyonlar sonucunda üçüncü döngü öncesinde tasarım ilkeleri belirlenerek tasarım son döngü öncesinde uygulamaya hazır hale getirilmiştir. Tasarlanan öğrenme ortamı ile ilgili ilkeler ilk iki döngü sonrasında Teknoloji Kullanımı, Temsil Dilleri, Ödevler, Çalışma Yaprakları ve Grup Çalışması olacak şekilde beş başlıkta oluşturulmuştur. Araştırmanın üçüncü döngüsünün ardından bilhassa öğrencilerin görüşlerinin analizi sonucunda Ders Öğretmenin Rolü adı altında altıncı bir başlık tasarım ilkelerine eklenmiştir. Böylelikle vektör uzaylarının öğretimine yönelik öğrenme ortamının tasarım ilkeleri altı başlık altında toplanmıştır. Ders öğretmeninin rolüne yönelik ilkeler aktif, işbirlikçi, yapının farkında, herkese eşit ve etkileşim içerisinde olmak olarak belirlenmiştir. Aslında araştırmacının uygulama süresince aktif ve öğrencilerle iş birliği içinde olmasını (Reeves, 2000) TTA'ların özelliklerinden biri olarak öğrenme ortamının görünmeyen bir ilkesi olduğunu ifade edebiliriz. Ancak öğrencilerin görüşleri analizi sonucunda ders öğretmeninin rolünün 
sadece bu özelliklerle sınırlı olmadığı ortaya konmuştur. bu çalışmada birinci ve ikinci döngüler araştırmacı tarafından üçüncü döngü ise alanında uzman bir matematik eğitimcisi tarafından yürütülmüştür. Bu nedenle ders öğretmeninin süreçten ve tasarım ilkelerinden haberdar olması ve bu ilkelere uygun bir şekilde dersi yürütmesi önemlidir. Çünkü etkinliklerin tamamında öğrencilerin düşünme biçimlerinin gelişimi için farklı dil ve gösterimlere belli bir sistematikle yer verilmiştir. Ders öğretmeninin bu yapının bilincinde olarak gerek süreç boyunca öğrencilerle etkileşiminde gerekse ders içi sunumlarında olsun dillerin kullanımına ve diller arası geçişlere özen göstermesi gerekmektedir. Aksi takdirde literatürde ifade edilen diller arası geçişlerin anlaşılmamasından kaynaklanan zorluklar (Hillel,2000) ile karşılaşılacaktır. Bununla birlikte öğrenciler ders öğretmenin herkese eşit davranmasını ve herkese söz hakkı vermesini kendilerini motive eden bir durum olduğunu ifade etmiştir. Öğrencilerin düşüncelerini açıkça ifade edebilmeleri bakımından ders öğretmeninin sergilediği bu davranışlar ve öğrencilerle olan iletişiminin (Pecuch-Herrero, 2000) oldukça önemli ve öğrencilerin başarısının artıran bir unsur olduğunu söylemek mümkündür.

Teknoloji kullanımı ile ilgili belirlenen ilkeler daha çok GeoGebra yazılımının öğrenme ortamındaki rolünü belirlemeye yönelik ilkelerdir. Öğrenme ortamında teknolojiye yer verilmesiyle sadece literatürdeki önerileri karşılamak değil aynı zamanda Harel'in (2000) önerdiği pedagojik prensiplerini uygulamak ve Dorier'in (1995) bahsettiği formalizm zorluğundan kaçınmak da amaçlanmıştır. Elde edilen bulguların analizi sonucunda belirtilen temel amaçların dışında GeoGebra yazılımı ile hazırlanan şablonların sahip olması gereken birtakım özellikler belirlenmiştir. Şablonların özellikleri dikkat çekici, pratik, içerikle uyumlu ve öğrencileri formal tanım ve ispatlara hazırlamak şeklinde belirlenmiştir. Dikkat çekici ve pratik kullanım her ne kadar GeoGebra şablonlarını hazırlarken dikkat edilen unsurlar olmasına rağmen teknoloji kullanımıyla ilgili ilkeler arasında yer almamıştır. Özellikle pratiklik, bütün öğrencilerin ve ders öğretmeninin görüş birliğine vardığı bir özelliktir ve zamanın etkin olarak kullanılmasında önemli bir rol oynamıştır. Bununla birlikte her ne kadar yazılımla ilgili uygulama öncesinde öğrencilere ders verilmiş olsa da bazı etkinlikler (alt uzay, germe) yazılımı kullanmaktan kaynaklanan ve sürenin uzamasına neden olan zorlukların ortaya çıkmasına neden olmuştur. Bu yüzden öğrencilere pratik kullanım sağlayacak bir şablonun hazırlanması, zamanı etkin kullanmak ve fazla sayıda örnek durumu ele almak ilkelerinin de karşılanmasına katkı sağlamıştır. Bununla birlikte tasarlanan GeoGebra şablonlarının içerik ve çalışma yapraklarıyla uyumlu olması görüşmelerde de ortaya çıkmıştır. Basit düzeyde BCS ve DGY kullanımının (Donevska-Todorova, 2018) lineer cebir öğretimini kolay bir hale getirmediği literatürde de yer almaktadır. Öğretim stratejileriyle birlikte uygulandığında teknolojinin öğrenci başarısını artırdığı (Donevska-Todorova, 2018; Pecuch-Herrero, 2000) dikkate alındığında tasarlanan şablonların derslerde kullanılan diğer etkinliklerle uyumlu ve belli bir sistematikle uygulanması gerektiği söylenebilir. Teknolojinin lineer cebir dersine entegre edilmesini sadece kavramlarla ilgili görsel temsillere yer vermek veya içeriği desteklemek olarak düşünmemek gerekir. Çalışma yaprakları ve ödevlerin de GeoGebra şablonları göz önünde bulundurularak düzenlenmesi ve etkinliklerin birbirini desteklemesi gerekmektedir. Ayrıca ders öğretmeni yazılımın sunmuş olduğu somut deneyimlerin öğrencilerin formal tanımları ve ispatları anlamalarına yardımcı olduğunu belirtmiş̧ir. Ders öğretmeninin belirtmiş olduğu bu görüş, Harel'in (2000) somutluk ve genellenebilirlik prensipleriyle bağdaşmakta olup bu görüşün teknoloji kullanımıyla ilgili ilkelerden biri olmasına karar verilmiştir.

Çalışma yapraklarının GeoGebra şablonlarıyla birlikte uygulandığı göz önüne bulundurulduğunda, yazılımla ilgili pratik kullanım da çalışma yapraklarının bir özelliği olarak ortaya çıkmaktadır. Çalışma yaprakları ilk döngüden itibaren gerek içerik olarak gerekse biçimsel olarak birçok düzenlemenin olduğu etkinliklerdir. Çalışma yaprakları hazırlanırken öğrencilerin kolaylıkla çözümlerini yapabilmeleri, çözümleri üzerinden varsayımlarda bulunabilmeleri ve ilişki kurabilmeleri için birçok biçimsel düzenlemeler yapılmıştır. Çünkü birinci ve ikinci döngüden elde edilen bulgular öğrencilerin dağınık bir şekilde çözüm yaptıklarını ve bazı zamanlar elde ettikleri sonuçları toparlamakta zorluk yaşadıklarını ortaya koymuştur. Her ne kadar öğrenme ortamına yönelik tasarım ilkeleri oluşturulurken çalışma yapraklarının pratik olarak hazırlanması bir ilke olarak ifade edilmese de çalşsma yapraklarının pratik olmasına dikkat edilmiştir. Sonuç olarak birinci ve ikinci döngülerin ardından çalışma yaprakları için belirlenen ilkeler merak etme, açık ve anlaşılır, genelleme yapma, farklı dillere yer verme, yazılımla uyumlu ve keşfetme olarak belirlenmiştir. Görüşlerden ve süreç boyunca yapılan gözlemler sonucunda pratik kullanımın çalışma yapraklarının hazırlanmasından dikkat edilecek hususlardan biri olmasına karar verilmiştir. Ders öğretmeni ve öğrencilerin görüşlerinden belirlenen ilkelerin çalışma yapraklarında başarılı bir şekilde karşılandığı ortaya çıkmıştır. Bununla birlikte gözlemler, çalışma yaprakları ve ödevlerin, öğrencilerin öğrenme ortamının amacını fark ettiklerini ve benimsediklerini ortaya koymuştur. Bu durum Harel'in (2000) gereklilik prensibinin karşılanmasına katkı sağladığı düşünülmektedir.

İlk iki döngü sonrası ödevler başlığı altında ilkeler; problem çözme, genelleme yapma, farklı dil ve gösterimlere yer verme olarak sunulmuştur. Gözlemlerden elde edilen bulgular ışığında ödevlerin öğrencilerin daha derinlemesine öğrenmelerinde ve sahip oldukları düşünme biçimlerini sergilemelerinde etkili olduğu sonucuna varılmıştır. Ödevlerle ilgili görüşlerin pekiştirici, dersi tekrar, sınava hazırlık, sınav stresini alma ve düzenli çalışma olarak belirlenmiştir. Öğrencilerin görüşlerinden hareketle ödevlerin öğrenmelerine olumlu bir katkı sağladığını söylemek mümkündür. Bununla birlikte ödevlerin bir zorunlu bir görev olarak görülmesi 
öğrencilerin görüşlerinde dikkat çekici bir durum olarak ortaya çıkmıştır. Bu duruma ödevlere düzenli bir şekilde dönütlerin verilmesinin ve öğrencilerin kendilerini derse karşı sorumlu hissetmelerinin neden olduğu düşünülmektedir. Ayrıca ders öğretmeniyle yapılan görüşmelerden sınıf içerisinde bir tartışma ortamının oluşturulmasında ödevlerin etkili olduğu sonucuna ulaşılmışıı. Bu nedenle ödevler başlığı altında belirlenen ilkelere; öğrenme, tartışma ve dönüt verme ilkelerinin de eklenmesine karar verilmiştir. Ancak burada dikkat edilecek bir diğer önemli nokta ise ödevlerin öğrencileri sınava hazır bir hale getirerek sınav stresi ve puan kaygısından kurtarmasıdır. Bu durumunda öğrencilerin sorulara verilen cevaplarda analitik-yapısal düşünme biçimi sergilemelerinde etkili olduğu sonucu güçlü bir şekilde düşünülmektedir. Ödevler aynı zamanda sınıfta bir tartışma ortamının oluşturulmasında önemli bir etkendir. Dersler süresince ödev soruları üzerinden öğrenciler düşüncelerini birbirleriyle paylaşarak sınıf tartışmaları gerçekleştirilmiştir. Bu durum hem öğrencilerin fikirlerini açıkça ifade etmelerini hem de ders öğretmeninin yanlış anlamaları belirleyerek bu yanlışlıkların düzeltilmesine olanak sağlamıştır. Dolayısıyla öğrencilerin fikirlerini ortaya koyması ve düşünme biçimlerinin gelişimi açısından ödevlerin sınıf içerisinde bir tartışılması ve üzerinde düşünülmüş sorulardan oluşmasının gerekliği olduğu düşünülmüştür. Tabi ki burada ders öğretmenin rolü de tartışma ortamının oluşmasında etkilidir. Öğrencilerin ödevleri yapmanın kendileri için bir sorumluluk ve zorunluluk olarak hissetmelerinde ödevlere verilen dönütlerinde etkisi olduğu düşünülmektedir. Ders öğretmeni ödevlere verilen dönütlerin öğrencileri motive ettiğini ifade etmiştir. Bu bakımdan, ödevlerin Harel'in (2000) gereklilik ve genellenebilirlik prensiplerini karşılamada önemli bir yerinin olduğu düşünülmektedir. Çünkü ödevler aynı zamanda bir problem çözme aktivitesi olarak düşünülebilir ve farklı dil ve gösterimlere yer vererek öğrencilerin en genel formda öğrenmelerine olanak sağlamaktır. Bu bakımdan böyle bir aktivitenin öğrenciler tarafından bir zorunluluk olarak görülmesinin sağlanabilmesi için dönüt verme, ödevler için bir ilke olarak belirlenmiştir. Öğrencilerin derse karş1 motivasyonları yüksek tutmuş ve dersi daha eğlenceli bir hale getirmiştir. Öğrencilerin, grup çalışması şeklinde yapılan laboratuvar derslerini sınıf derslerine tercih etmeleri formalizmin öğrencileri ne derece yorduğunun bir göstergesi olarak yorumlanabilir. Bu bağlamda grup çalışmalarının literatürde belirtilen formalizm zorluğuna (Dorier, 1995) karş1 öğrencileri motive ettiğini söylemek mümkündür. Sonuç olarak formalizm zorluğuna karş1 literatürde yer alan önerilere (Harel, 2000; Tabaghi, 2012) ek olarak derslerin zaman zaman grup çalışmas1 şeklinde yapılması da eklenebilir.

\section{Sonuç ve Öneriler}

Bu çalışmada Lineer Cebir öğretimi üzerine kuramsal çerçeve göz önünde bulundurularak vektör uzaylarının öğretimine yönelik teknoloji destekli bir öğrenme ortamının tasarım ilkelerinin belirlenmesi amaçlanmıştır. İlk iki döngü sonrasında beş başlık altında toplanan tasarım ilkeleri üçüncü döngü sonrasında elde edilen bulguların analizi sonucunda öğretmenin rolü başlığının eklenmesiyle altı başlık altında toplanmış ayrıca bazı başlıklara eklemeler yapılarak ilklere son hali verilmiştir. Araştırma sonucunda tasarım ilkeleri, teknoloji kullanımı, temsil dillerinin kullanımı, ödevler, çalışma yaprakları, grup çalışması ve öğretmenin rolü olarak belirlenmiştir.

Teknoloji kullanımına dikkat çekme, uyumlu, pratik ve formal tanım ve ispatlara zemin hazırlama; ödevlere öğrenme, tartışma ve dönüt verme; grup çalışmasına formalizm zorluğundan kaçınmak ilkeleri eklenmiştir. Tasarım ilkeleri belirlenirken ilk olarak araştırmanın kuramsal çerçevesi doğrultusunda ilkeler belirlenmiş ardından literatürde lineer cebir öğretimine yönelik öğrenci zorlukları ve öneriler dikkate alınarak bir öğrenme ortamı tasarlanmıştır. Öğrenme ortamının bileşenleri olan GeoGebra şablonları, çalışma yaprakları ve ödevler hazırlanırken kavramların geometrik, cebirsel ve soyut dilde gösterimlerine yer verilmiş bununla birlikte her bileşende somutluk, gereklilik ve genellenebilirlik prensiplerinin karşılanmasına yönelik olarak etkinlikler hazırlanmıştır. Böylece vektör uzaylarının öğretimine yönelik olarak tasarlanan bir öğrenme ortamının tasarım ilkeleri oluşturulmuştur.

Teknoloji kullanımı;

- Cebirsel ve grafiksel gösterimler arasında bağlantı kurmak

- Somutlaştırma ve görselleştirme

- Formalizm zorluğundan kaçınmak

- Zamani etkin kullanmak

- Fazla sayida soruya yer vermek

- Dikkat çekme

- Pratik ve uyumlu

- Formal tanım ve ispatlara zemin hazırlama

Derslerde teknolojiye yer verilirken hazırlanan materyallerin öğrencilerin kavramların cebirsel ve grafiksel gösterimleri arasında ilişkili kuracak şekilde tasarlanması önemlidir. Bu materyallerde kavramların somut gösterimlerine yer verilmesi öğrencilerin formalizm zorluğundan kaçınmasına imkan sağlamasının yanı sıra sezgisel anlamalar üzerinden öğrencilerin formal tanım ve ispatlara zemin hazırlamasına olanak sağlamaktadır. Bunun dışında, hazırlanan teknoloji materyallerinin dikkat çekici, pratik ve derste kullanılan diğer materyallerle 
uyumlu olacak şekilde tasarlanması sahip olmaları gereken özellikler arasındadır. Ayrıca öğrencilerin anlamalarını zenginleştirmek için kavramlarla ilgili olası bütün durumlara örnek teşkil edecek şekilde fazla sayıda sorulara yer verilmesi ve zamanı etkili bir şekilde kullanacak şekilde teknolojiye yer verilmesi önemlidir.

Temsil dillerinin kullanımı;

- Ödevler

- Çalışma yaprakları

- GeoGebra şablonları

- Ders içi sunumlar

Ödevler, çalışma yaprakları, GeoGebra şablonları tasarlanırken ve ders içi sunumla yapılırken temsil dillerinin kullanımına özen gösterilmesi ve farklı dillere yer verilmesi son derece gereklidir. Diller arasından yapılan geçişlerin öğrenciler tarafından anlaşılır olması ve öğrencilerin farklı dillerini kullanımına teşvik edilmesi ögrrenme ortamının temel ilkelerinden biridir. Ayrıca öğrencilerin düşünme biçimlerinin gelişimi açısında da önemlidir.

Ödevler;

- $\quad$ Problem çözme

- Genelleme yapma

- Farklı dil ve gösterimlere yer verme

- Öğrenme

- Tartışma

- Dönüt verme

Ödevler tasarlanırken temsil dillerinin kullanımı ilkesine uygun olarak sorularda kavramlara ilişkin farklı dillere yer verilmesi gerekmektedir. Ödevlerin aynı zamanda bir problem çözme aktivitesi olarak görülerek öğrencileri genelleme ve tartışma yapmaya götürecek düşündürücü düzeyde sorulardan oluşması gerekmektedir. Bununla birlikte ödevlere dönüt verilmesi öğrencilerin öğrenmeleri ve motivasyonlarını yüksek tutmak açısından önemli bir faktör olarak ortaya çıkmıştır.

Çalışma yaprakları;

- Merak uyandirma

- Açık ve anlaşılır olma

- Pratik

- Genellemeye yapma

- Farklı dillere yer verme

- Uyumlu

- Keşfetme

Tıpkı ödevlerde olduğu gibi çalışma yaprakları da tasarlanırken kavramlara ilişkin farklı dillere yer verilmesi gerekmektedir. Çalışma yaprakları, geometrik uygulamalarla başlayan, bu uygulamalarla ulaşılan sonuçları cebirsel yaklaşımlarla destekleyen ve en sonunda öğrencileri genelleme yapmaya götüren, öğrencilerin keşfederek öğrenmelerine imkan sunan bir yapıya sahip olması oldukça önemlidir. Bunun dışında çalışma yaprakları gerek içerik gerekse biçimsel açıdan merak uyandırıcı, açık ve sade yönergelere sahip, kullanışlı ve derste kullanılan diğer materyallerle uyumlu olma özelliklerine sahip olarak tasarlanmıştır.

Grup çalışması;

- Öğrenci merkezli

- Tartışma

- Motivasyon

- Formalizm zorluğundan kaçınmak

Etkinliklerin grup çalışması şeklinde yapılması literatürde yer alan öğrenci merkezli öğretim önerilerini karşılamanın dışında öğrenci sorumluluk ve aktif katılımı açısından da önemlidir. Grup çalışması formalizmin öğrencileri yormasının önüne geçilmesinde, birbirleriyle tartışma imkanı sunulmasında ve derse karşı motivasyonlarının daha yüksek olmasında etkili bir unsur olarak görülmüştür.

Öğretmenin rolü;

- Aktif

- İşbirlikçi

- Etkileşim içerisinde 
- Herkese eşit

- Yapının farkında

Öğrencilerin derse aktif katılımlarını sağlamak, öğrencilerin yanlış veya eksik bilgilerini ortaya çıkarmak ve düşünme biçimlerinin gelişimi açsından ders öğretmeninin aktif, işbirlikçi ve etkileşim içinde olması son derece önemlidir. Ders öğretmeni öğrenme ortamında çalışma yaprakları ve geogebra şablonlarının uyum içerisinde yürütülmesi, ödevlere dönüt verilmesi ve sınıf içinde tartışma ortamı oluşturması bakımından sorumluluklara sahiptir. Bu bakımdan araştırma bize ders öğretmeninin öğrenme ortamında izlenen sürecin ve kullanılan yapının fakında olması gerektiğini söylemektedir. Bunun dışında öğrencilere söz hakkı vermek ve düşüncelerini ifade etmelerine olanak sağlamak, öğrencilere kendilerini ifade etme firsatı verilmesi, farklı dilleri kullanması ve sahip oldukları düșünme biçimlerinin belirlenmesinde oldukça önemli bir sonuç olarak ortaya çıkmıștır.

Araştırmanın tasarım ilkeleri ortaya konulurken öğrenme ortamında ders öğretmeninin rolünün önemine dikkat çekilmiştir. Ders öğretmeninin öğrenme ortamındaki performansı öğrencilerin da dikkatini çekmiş ve onları motive etmiştir. Burada lineer cebir ders öğretmenleri için dikkat edilecek hususlardan biri tasarlanan öğrenme ortamı ders öğretmeninin sorumluluklarını artırmaktadır. Elbette normal sınıf ortamında da öğretmenlerin sorumlulukları vardır ancak birçok farklı öneri ve tasarım ilkeleri doğrultusunda hazırlanan bir öğrenme ortamı benimsenen öğrenme stratejileriyle birlikte farklı bakış açısına ve ek sorumluluklara ihtiyaç duymaktadır. Bu bakımdan benzer bir öğrenme ortamında yer alacak bir araştırmacıya veya bu tarz bir yaklaşımı benimseyen bir öğretmenin aşağıdaki noktalara dikkat etmesi gerekmektedir:

1. Etkinlikler arasındaki senkronizasyondan sorumlu olmak

2. Tartışma ortamı oluşturmak

3. Öğrencilerle etkileşim içerisinde olmak ve herkese söz hakkı vermek

4. Diller arasındaki geçişlere dikkat etmek

Teknolojinin günümüz eğitim dünyasında sınıflardaki yeri yadsınamaz bir boyuttadır. Sadece lineer cebir derslerinden değil ilköğretimden üniversiteye birçok farklı branşta teknolojik materyaller sınıflardaki yerlerini almaktadır. Bununla birlikte geçmişten günümüze ödevlerin kavramların öğretiminde önemli bir yeri olduğunu da unutmamak gerekir. Nitekim bu çalışmada da öğrencilere her hafta düzenli olarak ödevler verilmiştir. Ancak tıpkı teknoloji kullanımında olduğu gibi basit düzeyde, belli bir stratejiyle desteklenmemiş ve dönüt verilmeyen ödevler öğrencilerin anlamalarına katkı sağlaması zor bir ihtimal olarak düşünülmektedir. Temsil dillerinin ders içi etkinliklerde ve ders kitaplarından özensizce kullanımın öğrenciler için bir zorluk olduğu göz önünde bulundurulursa ödevlerinde öğrencilerin ayırımını yapabilecekleri şekilde farklı temsil dillerini içerek şekilde hazırlanması gerekmektedir. Buradan hareketle kavramların geometrik, cebirsel ve soyut temsillerinin yer aldığı, ders öğretmeni tarafından düzenli olarak dönüt verilen ve kavram odaklı ödevlerin vektör uzayları kavramlarının öğretiminde kullanılması önerilmektedir. Ayrıca ilerleyen zamanlarda teknolojide yaşanan değişiklikler de göz önünde bulundurularak lineer cebir öğretiminde yeni materyallerin ve öğrenme ortamlarının tasarlanması bakımından benzer çalışmaların yapılması da önerilmektedir.

\section{Kaynaklar / References}

Aydın, S. (2007). Bazı özel öğretim yöntemlerinin lineer cebir öğrenimine etkisi. Elektronik Sosyal Bilimler Dergisi, 6, 214-223.

Aydin, S. (2009b). The factors effecting linear algebra. Procedia Social and Behavioral Sciences, 1, 1549-1553.

Baki, A., Güven, B. ve Karataş, İ., (2002, Eylül). Dinamik geometri yazılımı cabri ile keşfederek ögrenme. V. Ulusal Fen Bilimleri ve Matematik Eğitimi Kongresi'nde sunulan bildiri, ODTÜ, Ankara.

Bogomolny, M. (2006). The role of example-generation tasks in students' understanding of linear algebra (Unpublished doctoral dissertation). Simon Fraser University, Canada.

Britton, S. and Henderson, J. (2009). Linear algebra revisited: An attempt to understand students' conceptual difficulties. International Journal of Mathematical Education in Science and Technology, 40(7), 963-974.

Carlson, D. (1993). Teaching linear algebra: Must the fog always roll in? The College Mathematics Journal, 24(1), 29-40.

Çekmez, E. (2013). Dinamik matematik yazılımı kullanımının öğrencilerin türev kavramının geometrik boyutuna ilişkin anlamalarına etkisi (Yayınlanmamış doktora tezi). Karadeniz Teknik Üniversitesi, Eğitim Bilimleri Enstitüsü, Trabzon.

Çelik, D. (2015). Investigating students' modes of thinking in linear algebra: The case of linear independence. International Journal for Mathematics Teaching and Learning, 16(1). Retrieved January 20, 2015 from http://www.cimt.org.uk/journal/index.htm.

Dikovic, L. (2007). Interactive learning and teaching of linear algebra by webtechnologies: Some examples. The Teaching of Mathematics, 10, 109-116.

Dogan, H. (2001). A comparison study between a traditional and experimental first-year linear algebra program (Unpublished doctoral dissertation). University of Oklahoma, USA 
Doğan-Dunlap, H. (2010). Linear algebra students' modes of reasoning: Geometric representations. Linear Algebra and Its Applications, 432, 2141-2159.

Donevska-Todorova, A. (2018). Fostering students' competencies in linear algebra with digital resources. In S. Stewart, C. Andrews-Larson, A. Berman \& M. Zandieh (Ed.) Challenges and Strategies in Teaching Linear Algebra (pp. 261-276). Hamburg: Springer International Publishing.

Dorier, J. L. (1995). Meta level in the teaching of unifying and generalizing concepts in mathematics. Educational Studies in Mathematics, 29, 175-197.

Dorier, J. L. (1998). The role of formalism in the teaching of the theory of vector spaces. Linear Algebra and its Applications (275), 14, 141-160.

Dorier, J. L. (2000). On the teaching of linear algebra. Dordrecht: Kluwer Academic.

Dorier, J. L., Robert, A., Robinet, J. and Rogalski, M. (2000). The obstacle of formalism in linear algebra. In J. L. Dorier (Ed.), On the teaching of linear algebra (pp. 85-124). Dordrecht: Kluwer Academic.

Dorier, J. L. (2002). Teaching linear algebra at university. Proceedings of ICM, 3, 875-884.

Dubinsky, E. (1997). Some thoughts on a first course in linear algebra at the college level. In D. Carlson, C. R. Johnson, D. Lay, A. D. Porter, A. E. Watkins \& W. Watkins (Eds.), Resources for teaching linear algebra (pp. 85-105). Washington: Mathematical Association of America.

Glesne, C. (2012). Nitel araştırmaya giriş (A. Ersoy ve P. Yalçınoğlu, Çev.). Ankara: Anı Yayıncılık.

Harel, G. (1987). Variations in linear algebra content presentations. For the Learning of Mathematics, 7(3), 2932.

Harel, G. (1989a). Learning and teaching linear algebra: Difficulties and an alternative approach to visualizing concepts and processes, Focus on Learning Problems in Mathematics 11, 139-148.

Harel, G. (1989b). Applying the principle of multiple embodiments in teaching linear algebra: Aspects of familiarity and mode of representation, School Science and Mathematics, 89, 49-57.

Harel, G. (1990). Using geometric models and vector arithmetic to teach high school students basic notions in linear algebra, International Journal for Mathematics Education in Science and Technology, 21, 387-392.

Harel, G. (2000). Principles of learning and teaching of linear algebra: Old and new observations. In J. L. Dorier (Ed.), On the teaching of linear algebra (pp. 177-189). Dordrecht: Kluwer Academic Publishers.

Herrington, J. A., McKenney, S., Reeves, T. C. and Oliver, R. (2007). Design-based research and doctoral students: Guidelines for preparing a dissertation proposal. In C. Montgomerie \& J. Seale (Eds.), Proceedings of EdMedia 2007: World Conference on Educational Multimedia, Hypermedia \& Telecommunications (pp. 4089-4097). Chesapeake, VA: AACE.

Hillel, J. and Sierpinska, A. (1994). On one persistent mistake in linear algebra. The Proceedings PME 18, 2, 65 72.

Hillel, J. (2000). Modes of description and the problem of representation in linear algebra. In J. L. Dorier (Ed.), On the teaching of linear algebra (pp. 191-207). Dordrecht: Kluwer Academic Publishers.

Hohenwarter, M., \& Jones, K. (2007). Ways of linking geometry and algebra: The case of GeoGebra, Proceedings of British Society for Research into Learning Mathematics, 27,3.

Hristovitch, S.P. (2001). Students' conception of introductory linear algebra notions: The role of metaphors, analogies and symbolization (Unpublished doctoral dissertation). Purdie University, USA.

Klasa, J. (2009). A few pedagogical designs in linear algebra with Cabri and Maple. Linear Algebra and its Applications, 432, 2100-2111.

Kolman, B. and Hill, D.R. (2008). Elementary linear algebra and its applications (9th ed.). New Jersey: Pearson Prentice Hall.

Kuzu, A., Çankaya, S. ve Mısırlı, A. (2011). Tasarım tabanlı araştırma ve öğrenme ortamlarının tasarımı ve geliştirilmesinde kullanımı. Anadolu Journal of Educational Sciences International, 1(1), 19-35.

National Council of Teachers of Mathematics [NTCM]. (2000). Principles and standards for school mathematics. Reston: VA.

Nardi, E. (1997). The novice mathematician's encounter with mathematical abstraction: A concept image of spanning sets in vectorial analysis. Educación Matemática, 91(1), 47-60.

Pecuch-Herrero, M. (2000). Strategies and computer projects for teaching linear algebra. International Journal of Mathematical Education in Science and Technology, 31, 181-186.

Reeves, T. C. (2000, April). Enhancing the worth of instructional technology research through "design experiments" and other development research strategies. Paper presented at the International Perspectives on Instructional Technology Research for the 21st Century, New Orleans, LA.

Robert, A. and Robinet, J. (1989). Quelques résultats sur l'apprentissage de l'algèbre linéaire en première année de DEUG, Cahier de Didactique des Mathématiques nº53, IREM de Paris VII.

Sierpinska, A., Dreyfus, T. and Hillel, J. (1999). Evaluation of a teaching design in linear algebra: The case of linear transformations. Recherches en Didactique des Mathématiques 19(1), 7-41.

Sierpinska, A. (2000). On some aspects of students' thinking in linear algebra. In J. L. Dorier (Ed.), On the teaching of linear algebra (pp. 209-246). Dordrecht: Kluwer Academic Publishers. 
Stewart, S. and Thomas, M. O. J. (2010). Student learning of basis, span and linear independence in linear algebra. International Journal of Mathematical Education in Science and Technology, 41(2), 173-188.

Stringer, E. (1999). Action research: A hand book for practitioners (2nd ed.). Thousand Oaks, CA: Sage Publications.

Tabaghi, S. G. and Sinclair, N. (2013). Using dynamic geometry software to explore eigenvectors: The emergence of dynamic-synthetic-geometric thinking. Technology, Knowledge and Learning, 18(3), 149-164.

Turğut, M. (2010). Teknoloji destekli lineer cebir öğretiminin ilköğretim matematik ögretmen adaylarının uzamsal yeteneklerine etkisi (Yayınlanmamış doktora tezi). Dokuz Eylül Üniversitesi, Eğitim Bilimleri Enstitüsü, İzmir.

Wang, F. and Hannafin, M. J. (2005). Design-based research and technology-enhanced learning environments. Educational Technology Research and Development, 53(4), 5-23.

Wu, H. (2004). Computer aided teaching in linear algebra. The China Papers, July, 100-102.

Yıldırım, A. ve Şimşek, H. (2005). Sosyal bilimlerde nitel araştırma yöntemleri. Ankara: Seçkin Yayınları. 